\title{
ELECTROMAGNETIC AND MAGNETIC AIRBORNE-GEOPHYSICAL SURVEY OF THE LIBERTY BELL AREA, WESTERN BONNIFIELD MINING DISTRICT, ALASKA (DATA COMPILATION): SURVEY OVERVIEW
}

Fugro Airborne Surveys Corp., Stevens Exploration Management Corp., Laurel E. Burns, and Gina R.C. Graham

Geophysical Report 2018-10

June 2018

STATE OF ALASKA

DEPARTMENT OF NATURAL RESOURCES

DIVISION OF GEOLOGICAL \& GEOPHYSICAL SURVEYS
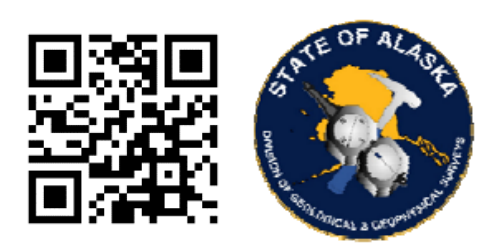


\section{STATE OF ALASKA}

Bill Walker, Governor

\section{DEPARTMENT OF NATURAL RESOURCES}

Andrew T. Mack, Commissioner

DIVISION OF GEOLOGICAL \& GEOPHYSICAL SURVEYS

Steve Masterman, State Geologist \& Director

Publications produced by the Division of Geological \& Geophysical Surveys are available to download from the DGGS website (dggs.alaska.gov). Publications on hard-copy or digital media can be examined or purchased in the Fairbanks office:

\section{Alaska Division of Geological \& Geophysical Surveys (DGGS) \\ 3354 College Road | Fairbanks, Alaska 99709-3707 \\ Phone: 907.451 .5010 | Fax 907.451.5050 \\ dggspubs@alaska.gov |dggs.alaska.gov}

\section{DGGS publications are also available at:}

Alaska State Library, Historical

Collections \& Talking Book Center

395 Whittier Street

Juneau, Alaska 99801

Alaska Resource Library and

Information Services (ARLIS)

3150 C Street, Suite 100

Anchorage, Alaska 99503

\section{Suggested citation:}

Fugro Airborne Surveys, Stevens Exploration Management Corp., Burns, L.E., and Graham, G.R.C., 2018, Liberty Bell area, western Bonnifield mining district, electromagnetic and magnetic airborne geophysical survey data compilation: Alaska Division of Geological \& Geophysical Surveys Geophysical Report 2018-10, 12 p.
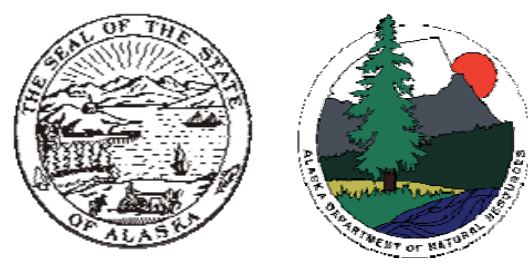


\section{ELECTROMAGNETIC AND MAGNETIC AIRBORNE-GEOPHYSICAL SURVEY OF THE LIBERTY BELL AREA, WESTERN BONNIFIELD MINING DISTRICT, ALASKA (DATA COMPILATION): SURVEY OVERVIEW}

Fugro Airborne Surveys Corp., Stevens Exploration Management Corp., Laurel E. Burns', and Gina R.C. Graham ${ }^{1}$

\section{ABSTRACT}

The Liberty Bell geophysical survey was originally flown in 2001 and published in 2002 (Alaska Division of Geological \& Geophysical Surveys and others, 2002) as a part of the State of Alaska's Airborne Geophysical/Geological Mineral Inventory (AGGMI) program. This publication supersedes the previous publications to provide a compilation of published and unpublished information and includes standardized databases and product formats, upgrades digital datasets to modern formats, and re-releases the historical survey and associated documentation (http://doi.org/10.14509/29690). This publication contains geophysical data produced from airborne surveys flown from the 24th to 27th of August 2001 for 2,023.6 line kilometers at 400m line spacing in the Bonnifield mining district, Alaska. This DIGHEMV electromagnetic/magnetic survey was flown by Fugro Airborne Surveys Corp. under contract to Stevens Exploration Management Corp.

\section{PURPOSE}

The Liberty Bell airborne magnetic and electromagnetic survey, located in the northern foothills of the Alaska Range of central Interior Alaska, covers part of the Bonnifield mining district, which contains known intrusion-related and placer gold deposits and occurrences. It is also prospective for porphyry copper \pm gold \pm molybdenum \pm silver, skarn, volcanogenic massive sulfide, and other deposit types. The survey is part of the AGGMI program to acquire data on Alaska's most promising mineral belts and districts aimed at catalyzing private sector exploration.

\section{SURVEY OVERVIEW DESCRIPTION}

This booklet provides a visual overview of available digital processed magnetic and electromagnetic datasets for the Liberty Bell geophysical survey (figs. 3-9). Each figure is accompanied by a brief summary of the data type, and associated data-recording instrumentation, sampling rate, and processing steps. All detailed survey specifications and data processing steps can be found in the associated metadata and readme files, as well as in the Liberty Bell project report. A catalog overviewing paper- and printable-format map sheets can be found in Table 1.

\footnotetext{
${ }^{1}$ Alaska Division of Geological \& Geophysical Surveys, 3354 College Road, Fairbanks, Alaska 99709-3707
} 
Electromagnetic and magnetic airborne-geophysical

survey of the Liberty Bell area

\section{AVAILABLE DATA}

\begin{tabular}{|c|c|c|}
\hline Data Type & Provider & Description \\
\hline ascii_data & contractor & ASCII format line data, other ASCII data \\
\hline databases_geosoft & contractor & $\begin{array}{l}\text { Geosoft format database of final line data, other Geosoft } \\
\text { format databases }\end{array}$ \\
\hline documents & contractor & $\begin{array}{l}\text { Project and field reports, survey background information, } \\
\text { gridded data explanations, other documentation }\end{array}$ \\
\hline grids_ermapper & contractor & Geographically registered gridded data, ER Mapper ERS format \\
\hline grids_geosoft & contractor & $\begin{array}{l}\text { Geosoft-format binary grids, these grids can be viewed in ESRI } \\
\text { ArcMap using a free plugin from Geosoft }\end{array}$ \\
\hline images_registered & DGGS & GeoTiff format images of all gridded data \\
\hline $\mathrm{kmz}$ & contractor & $\mathrm{kml}$ language kmz archive files of project data \\
\hline maps_pdf_format & contractor & Printable maps in pdf format \\
\hline maps_prn_format & contractor & $\begin{array}{l}\text { Printable maps in HPGL/G printer file format with extension } \\
\text {.prn }\end{array}$ \\
\hline profiles_stacked_pdf & contractor & $\begin{array}{l}\text { Electromagnetic and magnetic data profiles with EM } \\
\text { anomalies, files in PDF format }\end{array}$ \\
\hline profiles_stacked_prn & contractor & $\begin{array}{l}\text { Electromagnetic and magnetic data profiles with EM } \\
\text { anomalies, files in PRN format }\end{array}$ \\
\hline vector_data & contractor & $\begin{array}{l}\text { Line path, data contours, and survey boundary in ESRI shape } \\
\text { file (SHP) format }\end{array}$ \\
\hline video_flightpath & contractor & Survey flight path downward facing video \\
\hline
\end{tabular}




\section{ACKNOWLEDGMENTS}

This project was funded by the State of Alaska's Airborne Geophysical/Geological Mineral Inventory (AGGMI) program.

\section{REFERENCES}

Akima, H., 1970, A new method of interpolation and smooth curve fitting based on local procedures: Journal of the Association of Computing Machinery, v. 17, n. 4, p. 589-602.

Alaska Division of Geological \& Geophysical Surveys, Fugro Airborne Surveys, Stevens Exploration Management Corp., and Burns, L.E., 2002, Line, grid, and vector data of airborne geophysical survey data for the Liberty Bell area, western Bonnifield mining district, central Alaska: Alaska Division of Geological \& Geophysical Surveys Geophysical Report 2002-7, 1 DVD. http://doi.org/10.14509/2807

Burns, L.E., Fugro Airborne Surveys Corp., Stevens Exploration Management Corp., Graham, G.R.C., and Emond, A.M., 2016, Bonnifield mining district electromagnetic and magnetic airborne geophysical survey data compilation: Alaska Division of Geological \& Geophysical Surveys Geophysical Report 2016-1, 2 sheets. http://doi.org/10.14509/29557

Geoterrex-Dighem, Fugro Airborne Surveys, Stevens Exploration Management Corp., Pritchard, R.A., Burns, L.E., Emond, A.M., and DGGS Staff, 2016, Sub-regional, merged, gridded airborne geophysical data: Alaska Division of Geological \& Geophysical Surveys Digital Data Series 12, 1 DVD. http://doi.org/10.14509/29555 


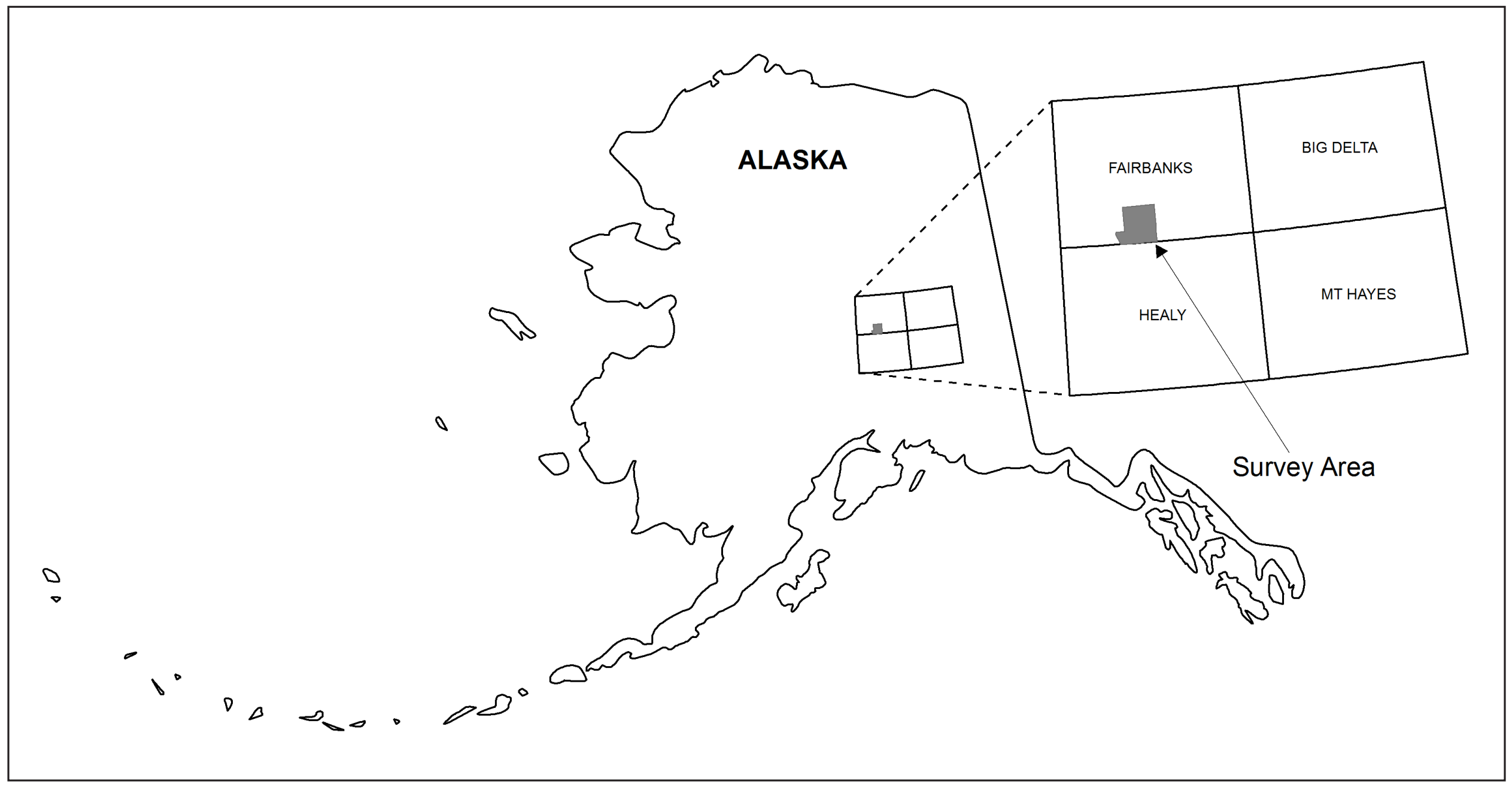

Figure 1. Liberty Bell survey area shown in relation to Fairbanks, Big Delta, Healy, and Mount Hayes 1:250,000-scale quadrangles. 


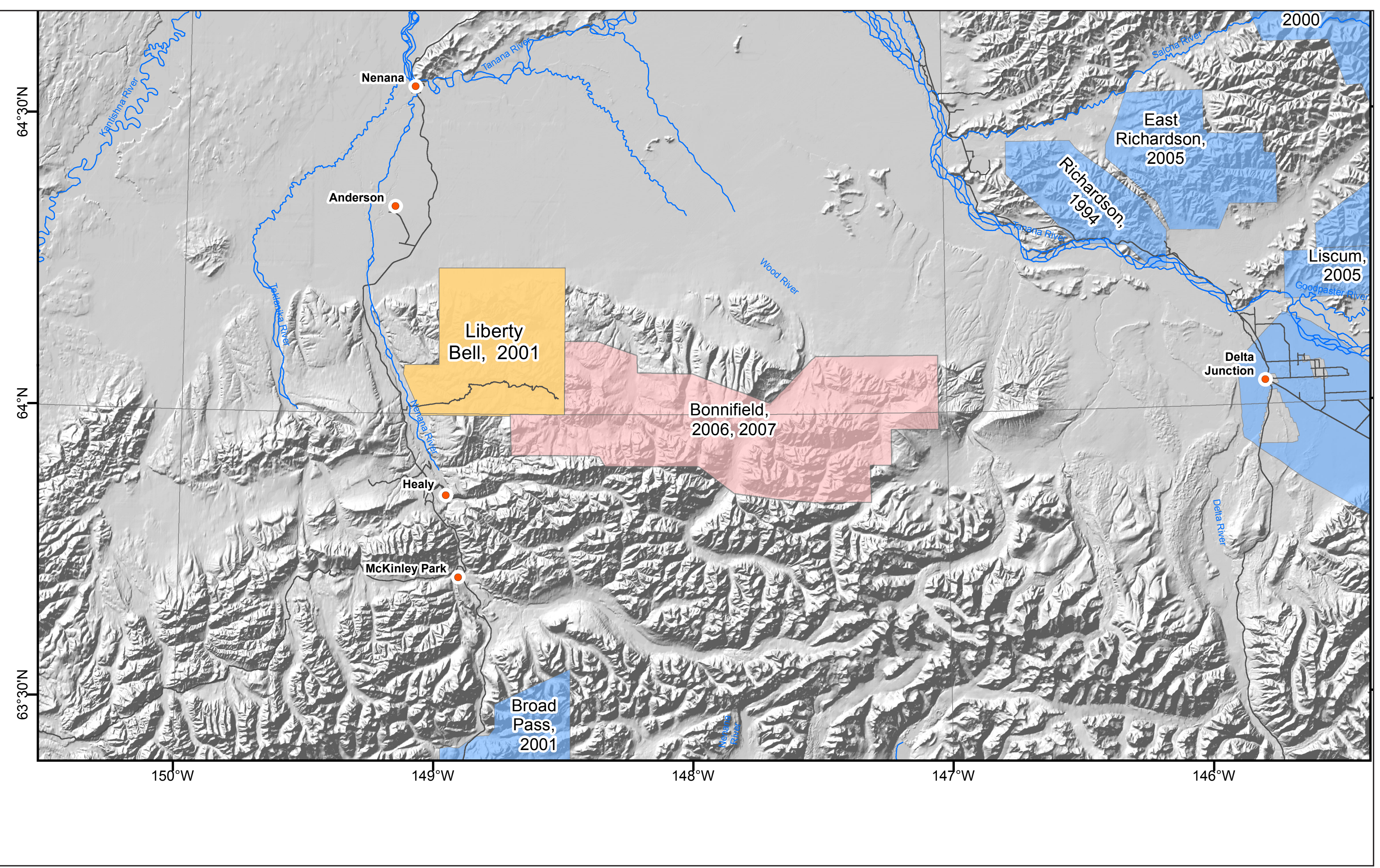

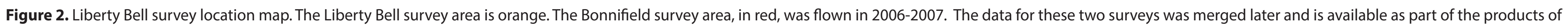
the Bonnifield survey (http://doi.org/10.14509/29557) Prior survey areas are shaded blue. Highways, towns, rivers and relevant quadrangle boundaries are included for reference. 


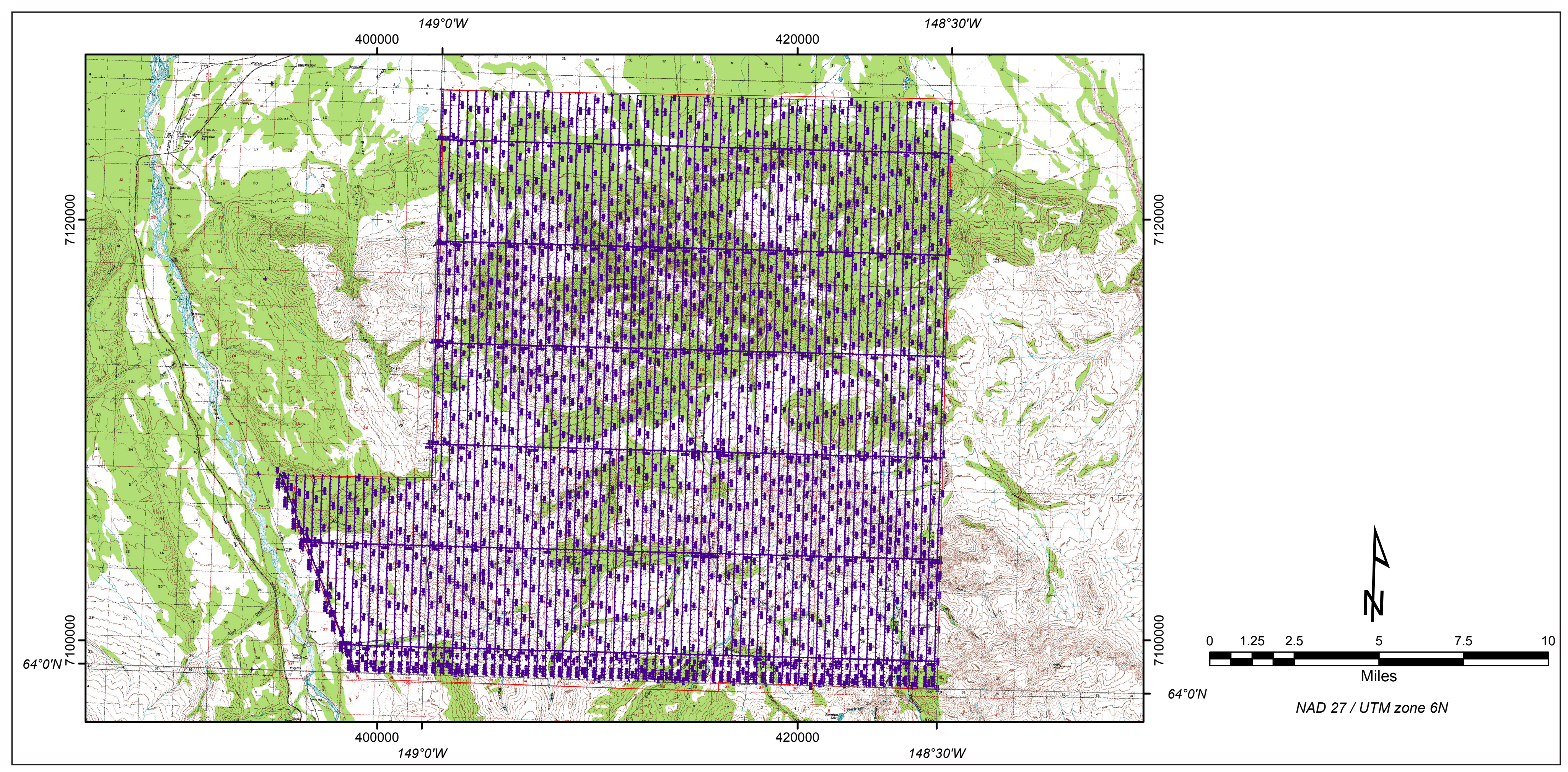

Figure 3. Flight lines and topography. Data types: Frequency domain electromagnetic and magnetic. Frequencies: coaxial 1000 and $5500 \mathrm{~Hz}$; coplanar $900 \mathrm{~Hz}, 7200 \mathrm{~Hz}$ and $56000 \mathrm{~Hz}$. Line spacing: 400 meters. 


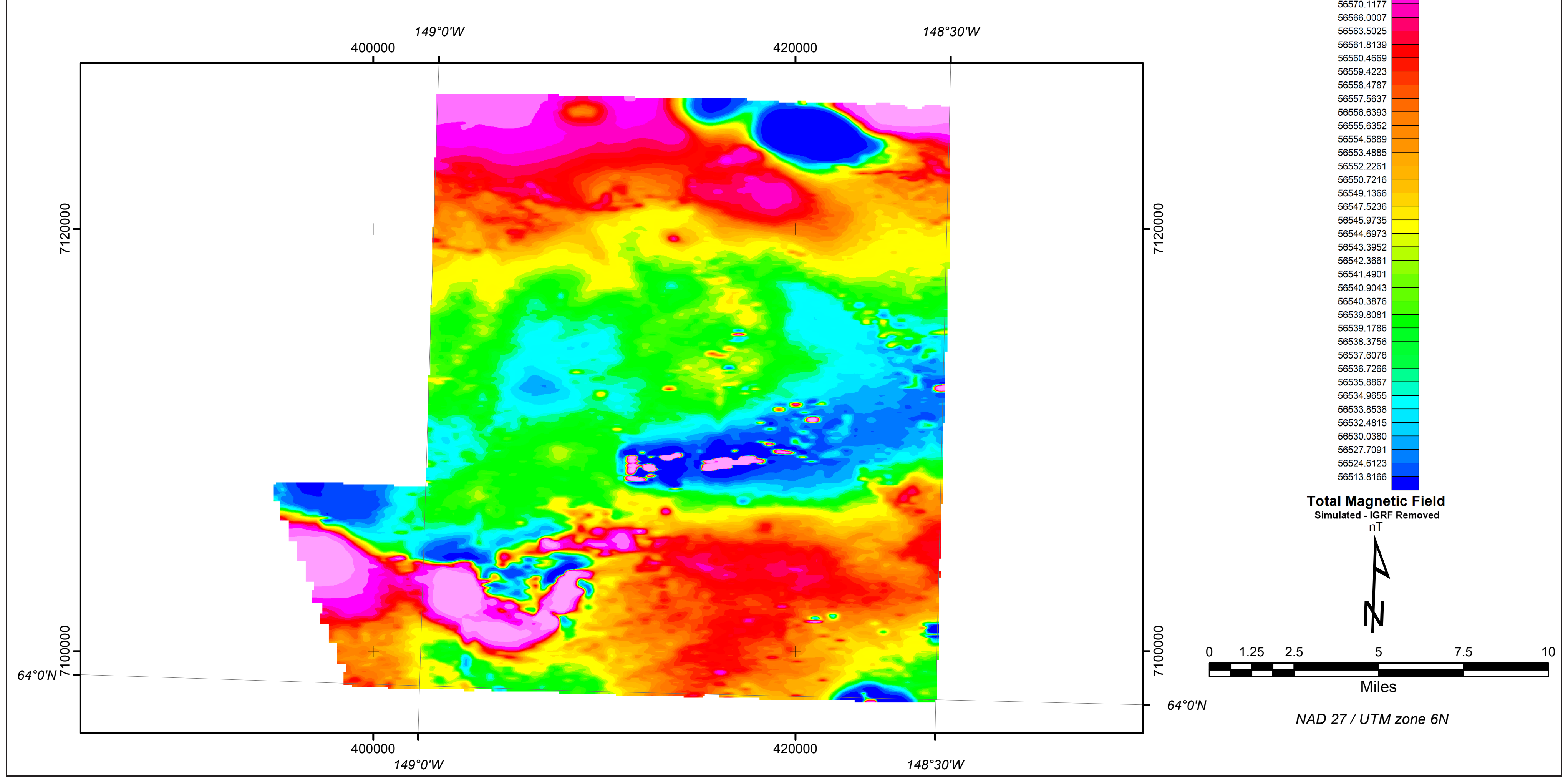

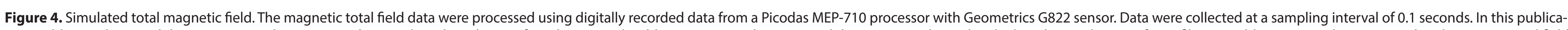

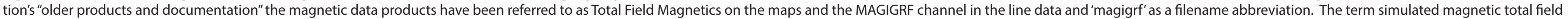

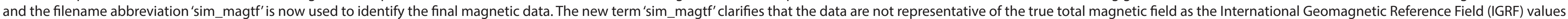

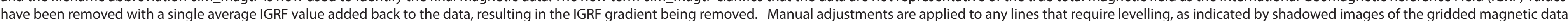

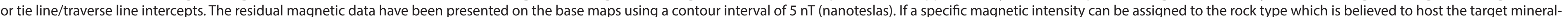

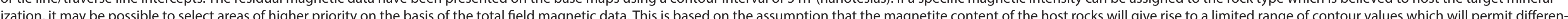

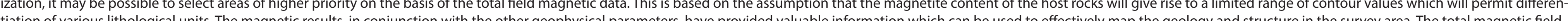

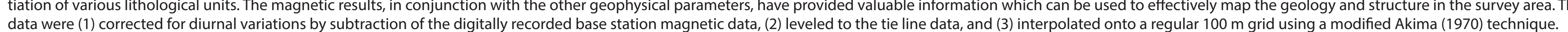



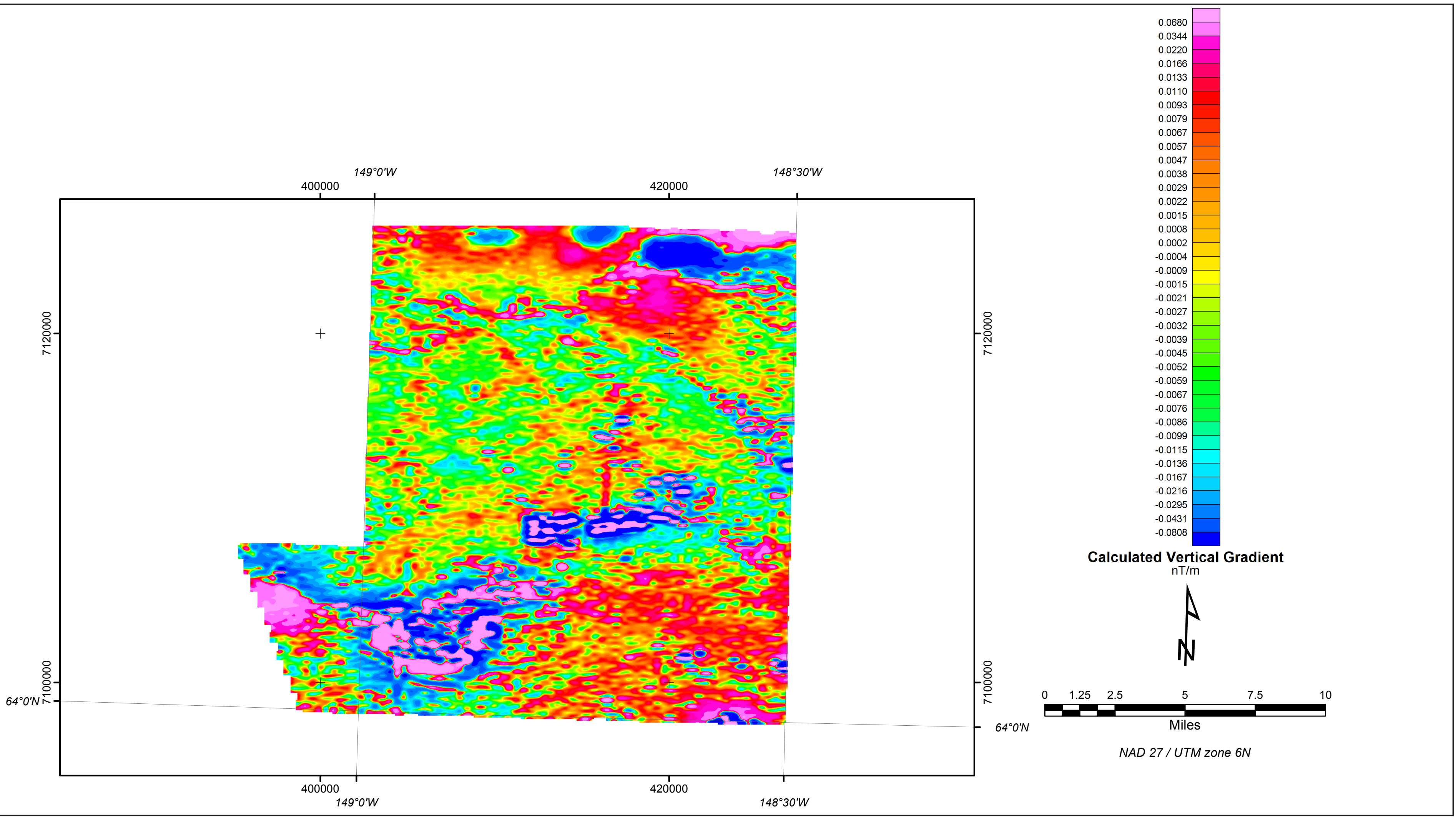

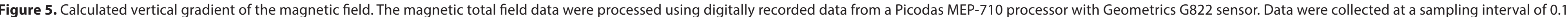

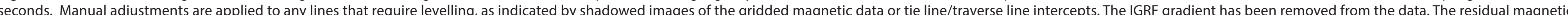

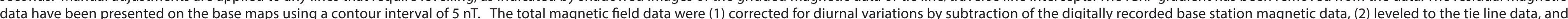

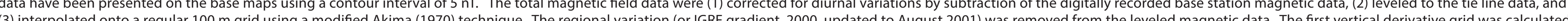

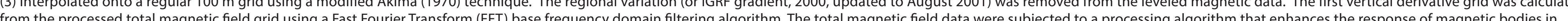

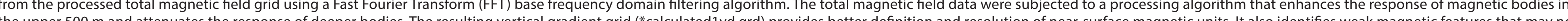
the upper 500 m and attenuates the response of deeperbodies. The resuling verticalgradent gid "'caculat 


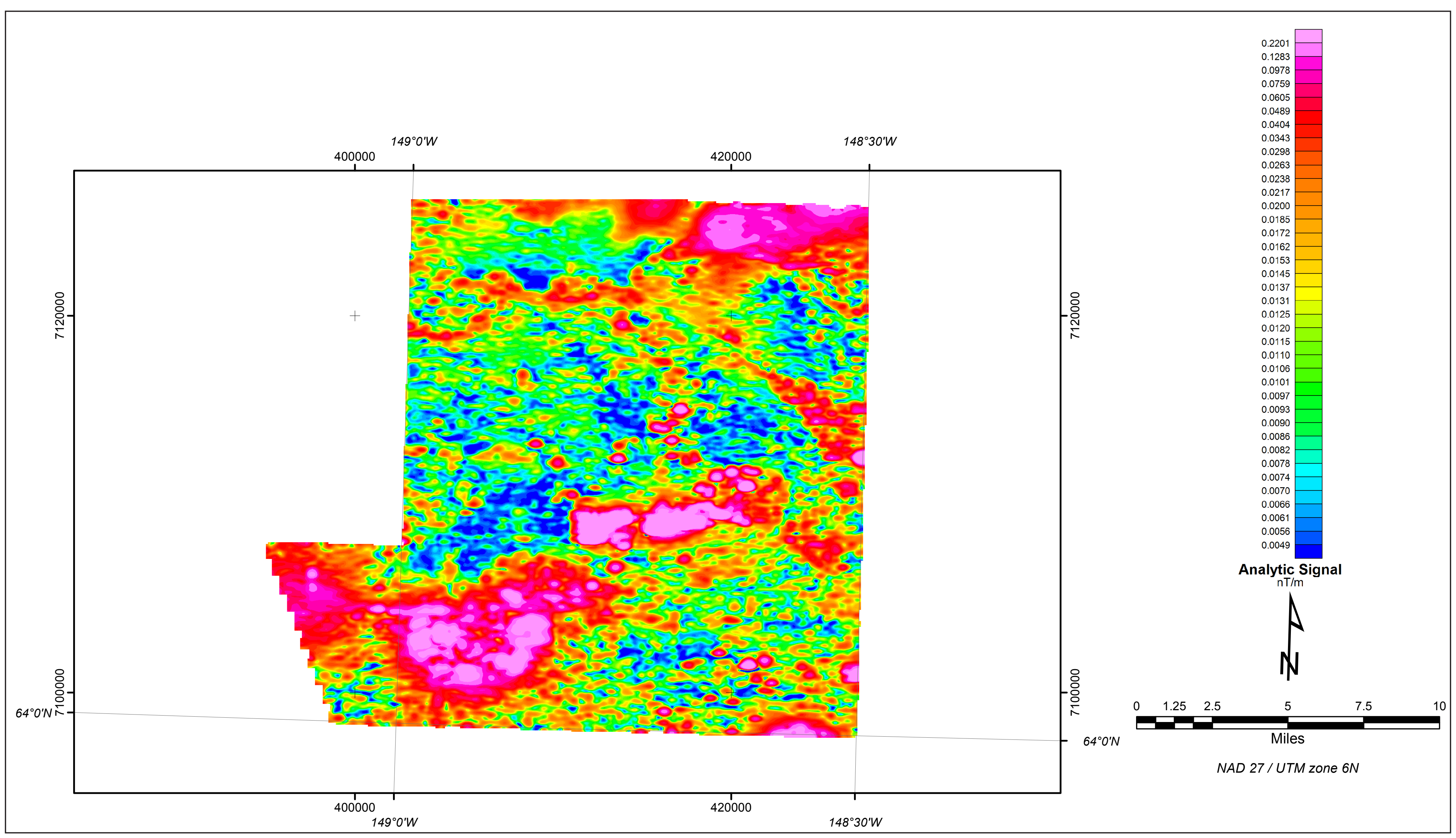

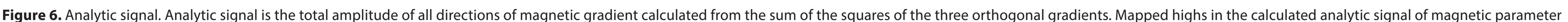

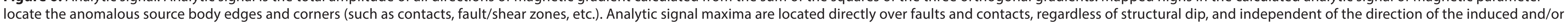
remanent magnetizations. 


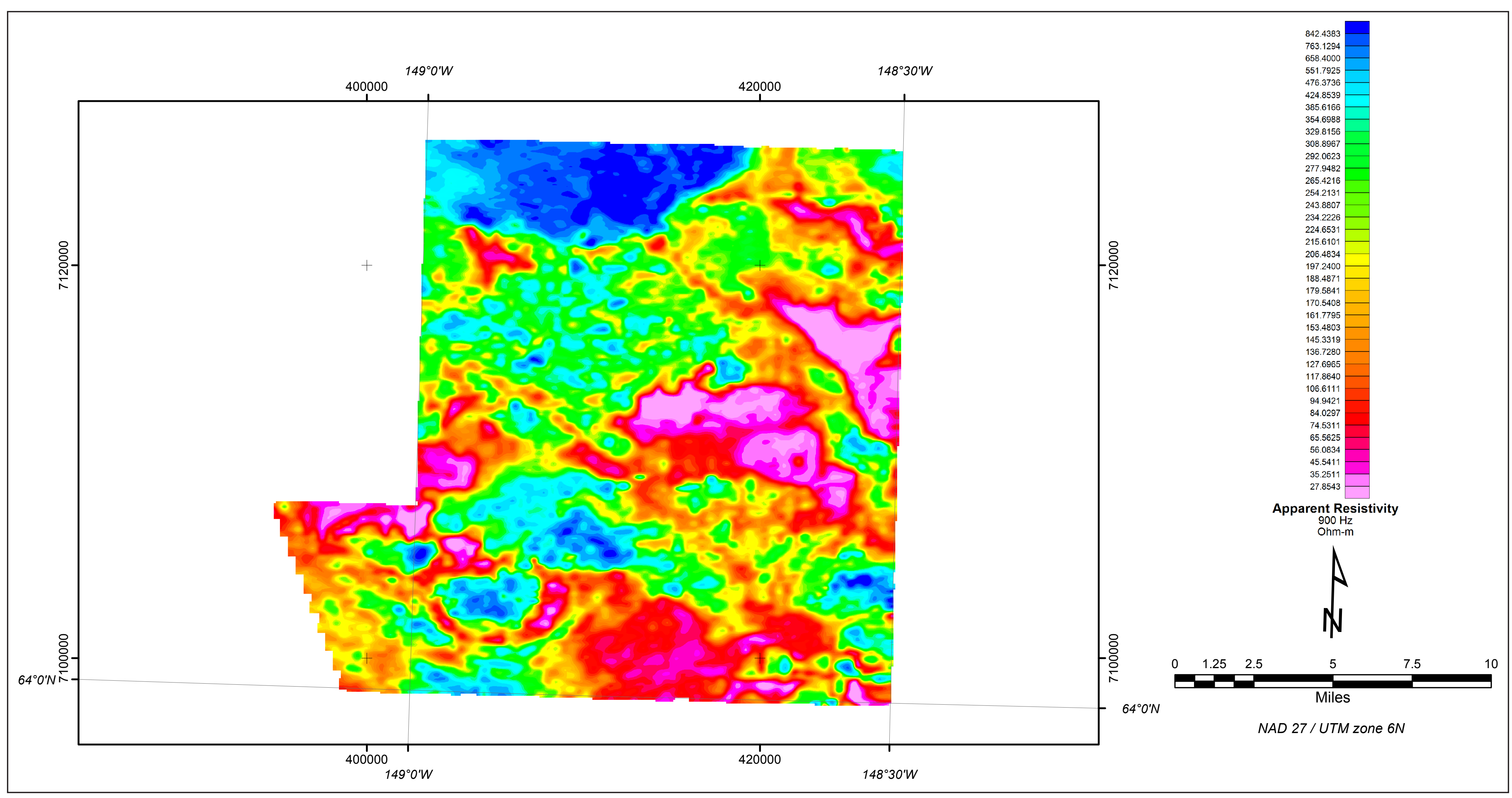

Figure 7. Resistivity $900 \mathrm{~Hz}$ Coplanar. The DIGHEM V EM system measured inphase and quadrature components at five frequencies. Two vertical coaxial-coil pairs operated at 1,072 $(1,000)$ and $5,954(5,500) \mathrm{Hz}$ while three horizontal coplanar-coil pairs operated at $883(900), 7,236(7,200)$, and $55,360(56,000) \mathrm{Hz}$. The EM data were sampled at 0.1 second intervals. The EM system responds to bedrock conductors, conductive overburden, and cultural sources. The EM inphase and quadrature data were drift corrected

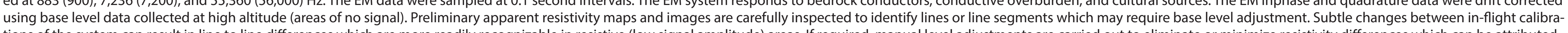

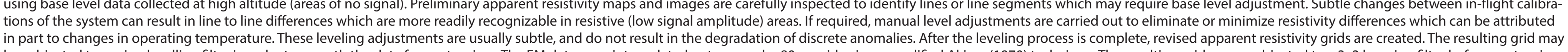

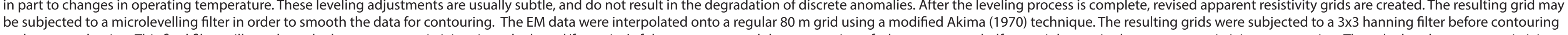

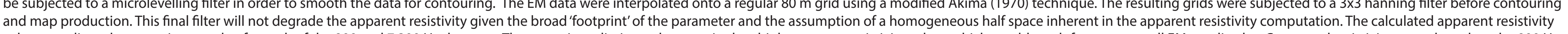

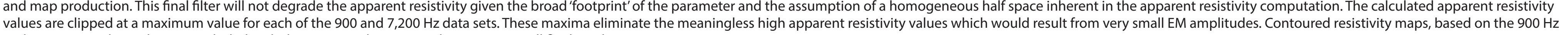
values are clipped at a maximum value for each of the 900 and $7,200 \mathrm{~Hz}$ data sets. These maxima eliminate 
400000

$149^{\circ} 0^{\prime} W$

420000

$148^{\circ} 30^{\prime} \mathrm{W}$

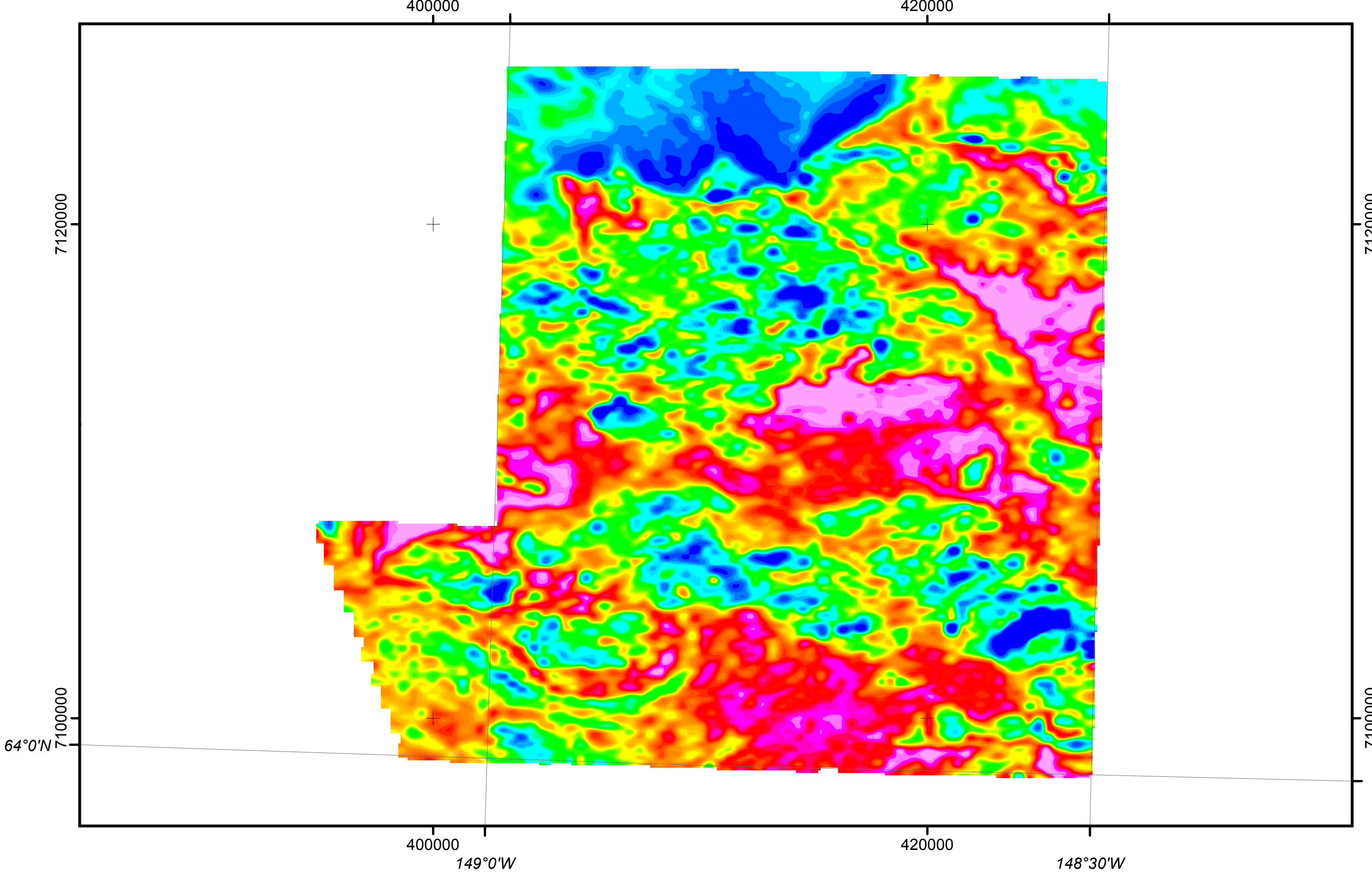

$148^{\circ} 30^{\prime} W$

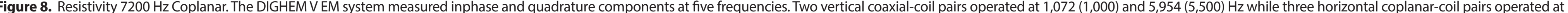

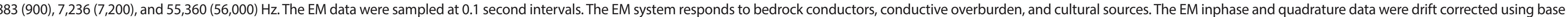

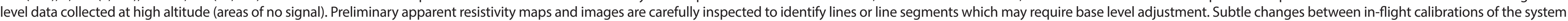

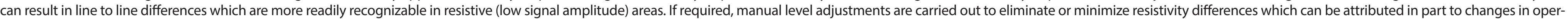

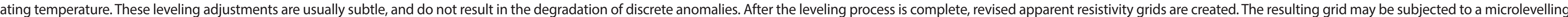

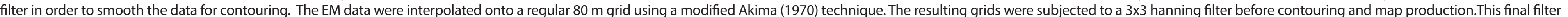

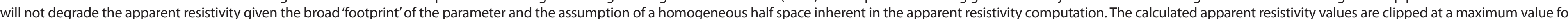

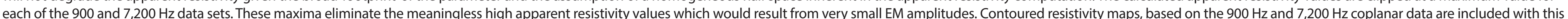
report. Values are in ohm-metres on all final products. 


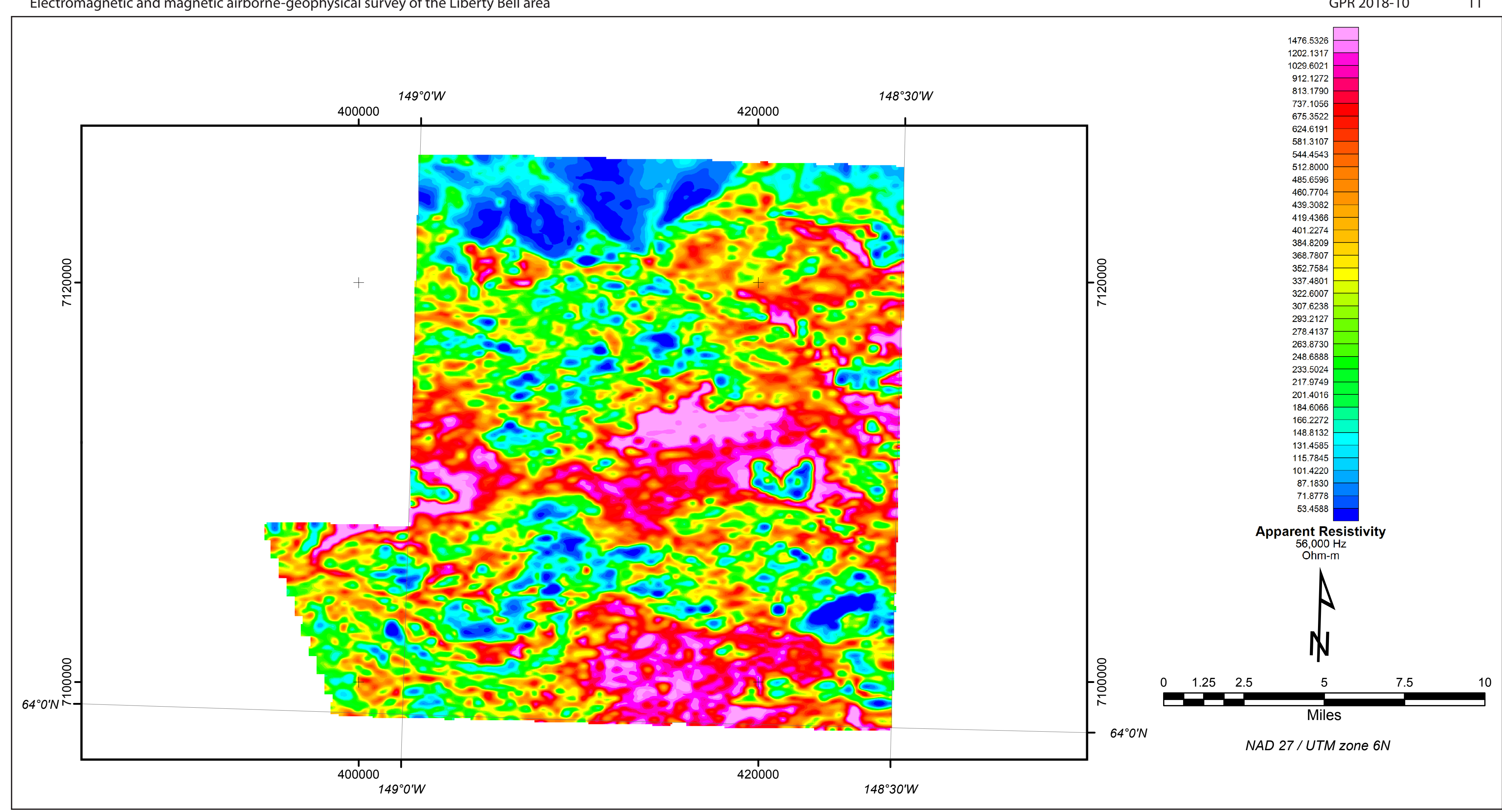

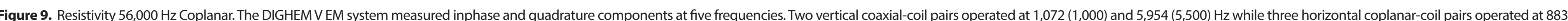

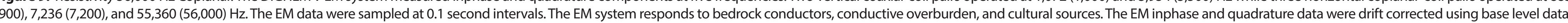

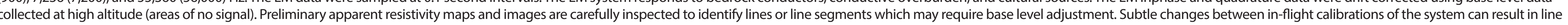

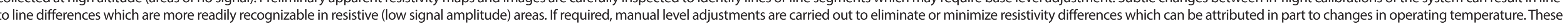

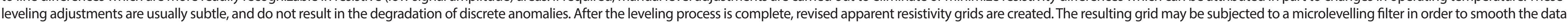

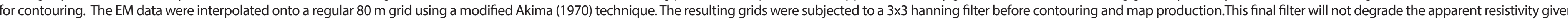

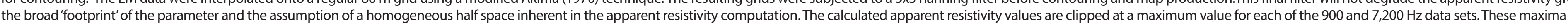

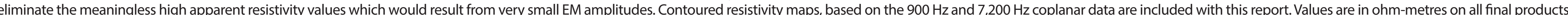


Table 1. Copies of the following maps are included at the end of this booklet. The low-resolution, page-size maps included in this booklet are intended to be used as a search tool and are not the final product. Large-scale, full-resolution versions of each map are available to download on this publication's citation page: http://doi.org/10.14509/29690.

\begin{tabular}{|c|c|c|c|}
\hline Map Number & Map Title & Description & Scale \\
\hline Geophysical Report 2002_6_5a & $\begin{array}{l}\text { Flight lines of the Liberty Bell area, western Bonnifield mining district, central } \\
\text { Alaska }\end{array}$ & Flight lines with topography & $1: 63,360$ \\
\hline Geophysical Report 2002_6_1a & $\begin{array}{l}\text { Total magnetic field of the Liberty Bell area, western Bonnifield mining district, } \\
\text { central Alaska }\end{array}$ & Color total magnetic field with topography & $1: 63,360$ \\
\hline Geophysical Report 2002_6_1b & $\begin{array}{l}\text { Total magnetic field of the Liberty Bell area, western Bonnifield mining district, } \\
\text { central Alaska }\end{array}$ & Color total magnetic field with contours and sections lines & $1: 63,360$ \\
\hline Geophysical Report 2002_6_1c & $\begin{array}{l}\text { Color shadow magnetic map of the Liberty Bell area, western Bonnifield mining } \\
\text { district, central Alaska }\end{array}$ & Color shadow total magnetic field with section lines & $1: 63,360$ \\
\hline Geophysical Report 2002_6_1d & $\begin{array}{l}\text { Total magnetic field and electromagnetic anomalies of the Liberty Bell area, } \\
\text { western Bonnifield mining district, central Alaska }\end{array}$ & $\begin{array}{l}\text { Black and white total magnetic field contours with section } \\
\text { lines and simplified EM anomalies }\end{array}$ & $1: 63,360$ \\
\hline Geophysical Report 2002_6_2a & $\begin{array}{l}\text { Total magnetic field and detailed electromagnetic anomalies of the Liberty } \\
\text { Bell area, western Bonnifield mining district, central Alaska, part of northern } \\
\text { Fairbanks A-4 Quadrangle }\end{array}$ & $\begin{array}{l}\text { Black and white total magnetic field contours with detailed } \\
\text { EM anomalies and topography }\end{array}$ & $1: 31,680$ \\
\hline Geophysical Report 2002_6_2b & $\begin{array}{l}\text { Total magnetic field and detailed electromagnetic anomalies of the Liberty Bell } \\
\text { area, western Bonnifield mining district, central Alaska, part of southern Fair- } \\
\text { banks A-4 and A-5 quadrangles }\end{array}$ & $\begin{array}{l}\text { Black and white total magnetic field contours with detailed } \\
\text { EM anomalies and topography }\end{array}$ & $1: 31,680$ \\
\hline Geophysical Report 2002_6_3b & $\begin{array}{l}7200 \mathrm{~Hz} \text { coplanar resistivity of the Liberty Bell area, western Bonnifield mining } \\
\text { district, central Alaska }\end{array}$ & $\begin{array}{l}\text { Color resistivity ( } 7200 \mathrm{hz} \text { coplanar) with contours and section } \\
\text { lines }\end{array}$ & $1: 63,360$ \\
\hline Geophysical Report 2002_6_3c & $\begin{array}{l}7200 \mathrm{~Hz} \text { coplanar resistivity of the Liberty Bell area, western Bonnifield mining } \\
\text { district, central Alaska }\end{array}$ & $\begin{array}{l}\text { Black and white resistivity ( } 7200 \mathrm{hz} \text { coplanar) contours with } \\
\text { section lines }\end{array}$ & $1: 63,360$ \\
\hline Geophysical Report 2002_6_4a & $\begin{array}{l}900 \mathrm{~Hz} \text { coplanar resistivity of the Liberty Bell area, western Bonnifield mining } \\
\text { district, central Alaska }\end{array}$ & Color resistivity (900 hz coplanar) with topography & $1: 63,360$ \\
\hline Geophysical Report 2002_6_4b & $\begin{array}{l}900 \mathrm{~Hz} \text { coplanar resistivity of the Liberty Bell area, western Bonnifield mining } \\
\text { district, central Alaska }\end{array}$ & $\begin{array}{l}\text { Color resistivity ( } 900 \mathrm{hz} \text { coplanar) with contours and section } \\
\text { lines }\end{array}$ & $1: 63,360$ \\
\hline Geophysical Report 2002_6_4c & $\begin{array}{l}900 \mathrm{~Hz} \text { coplanar resistivity of the Liberty Bell area, western Bonnifield mining } \\
\text { district, central Alaska }\end{array}$ & $\begin{array}{l}\text { Black and white resistivity ( } 900 \mathrm{hz} \text { coplanar) contours with } \\
\text { section lines }\end{array}$ & $1: 63,360$ \\
\hline Geophysical Report 2002_9 & $\begin{array}{l}\text { Interpretation map of the Liberty Bell area, western Bonnifield mining district, } \\
\text { central Alaska }\end{array}$ & Interpretation map with section lines & $1: 63,360$ \\
\hline
\end{tabular}




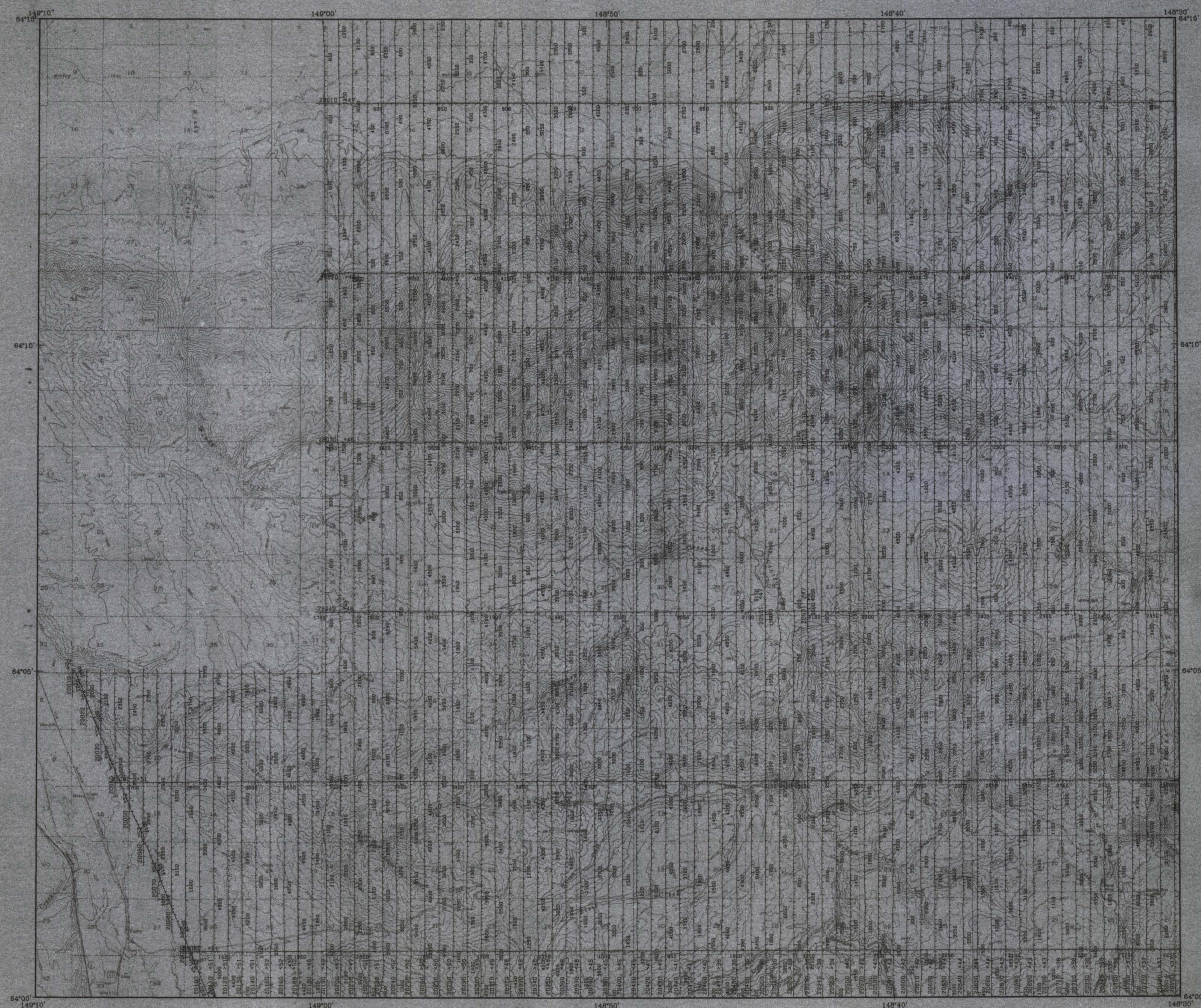

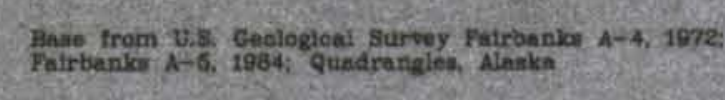

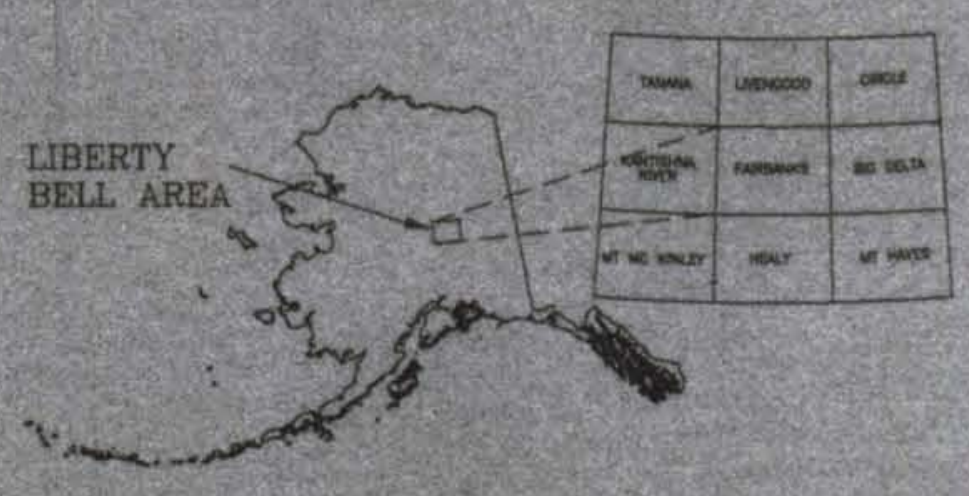

i)

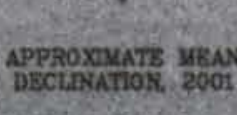

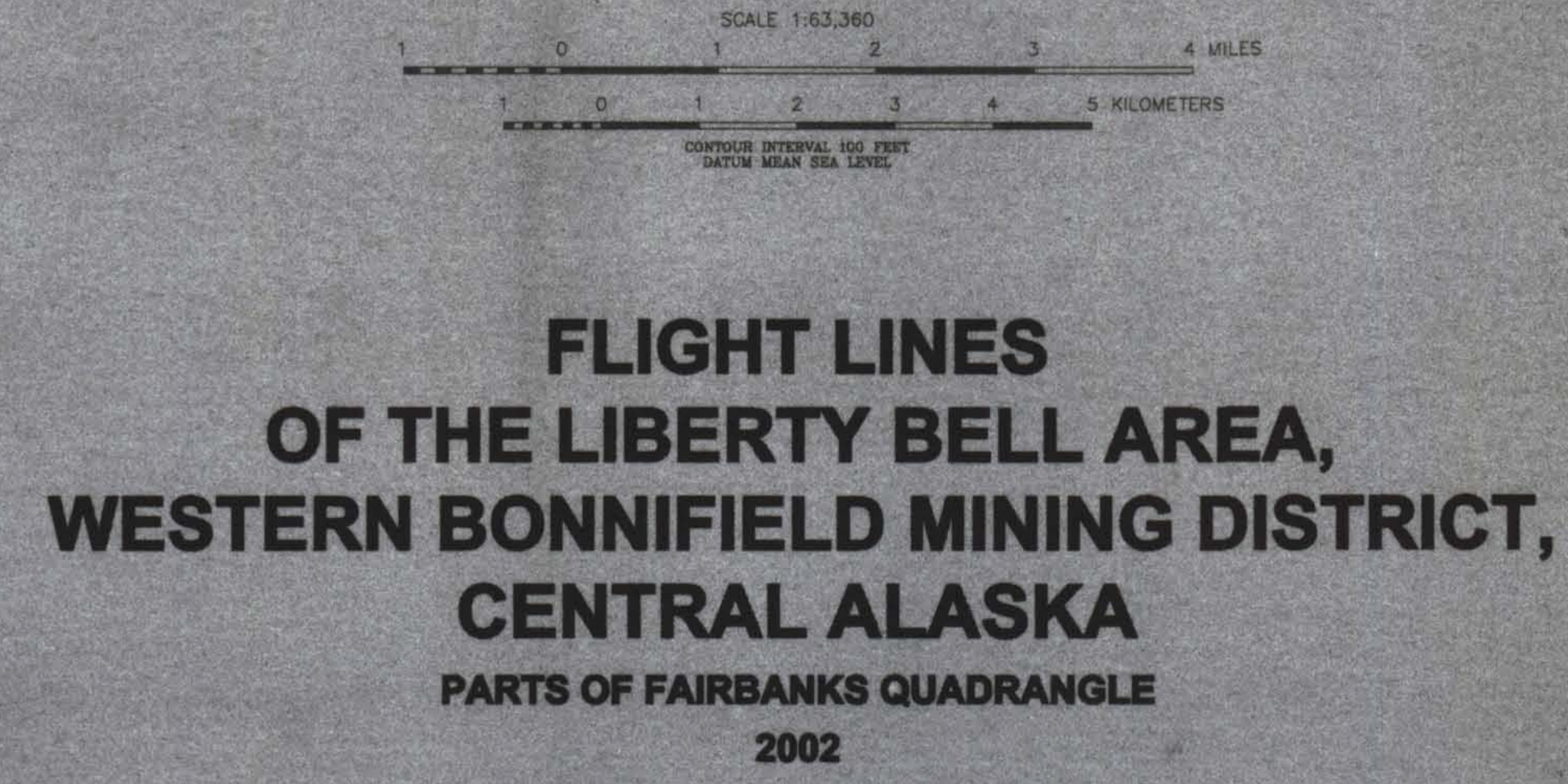

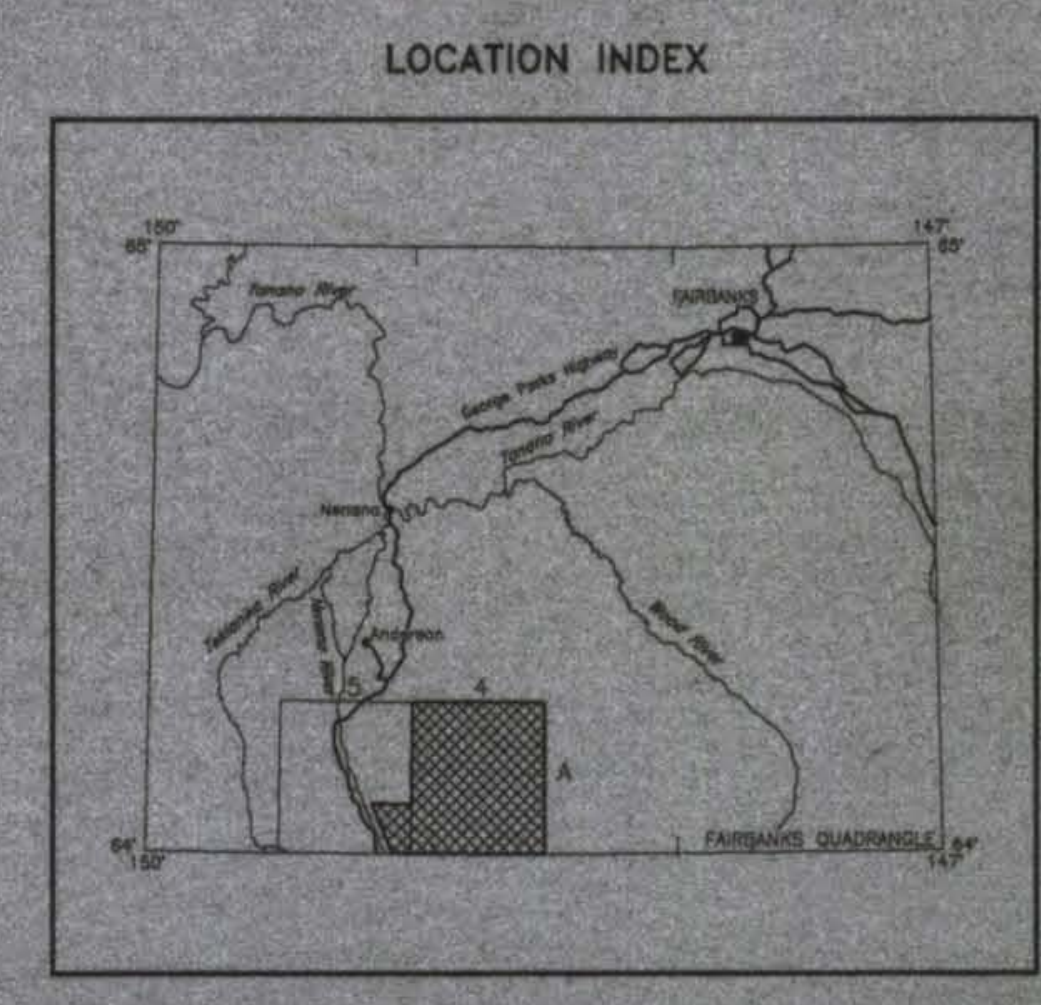

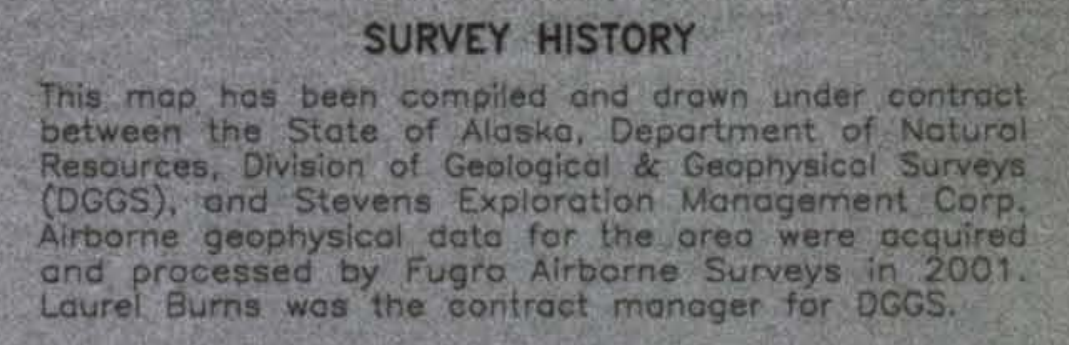

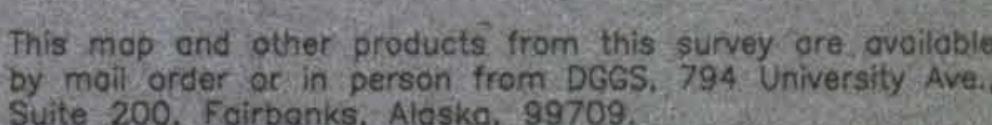

FLIGHT LINES

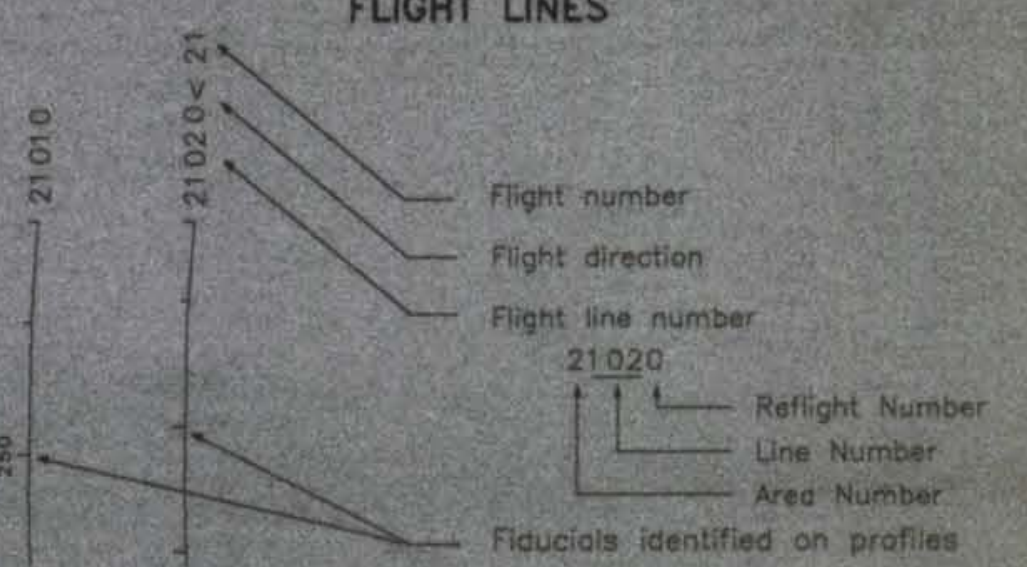




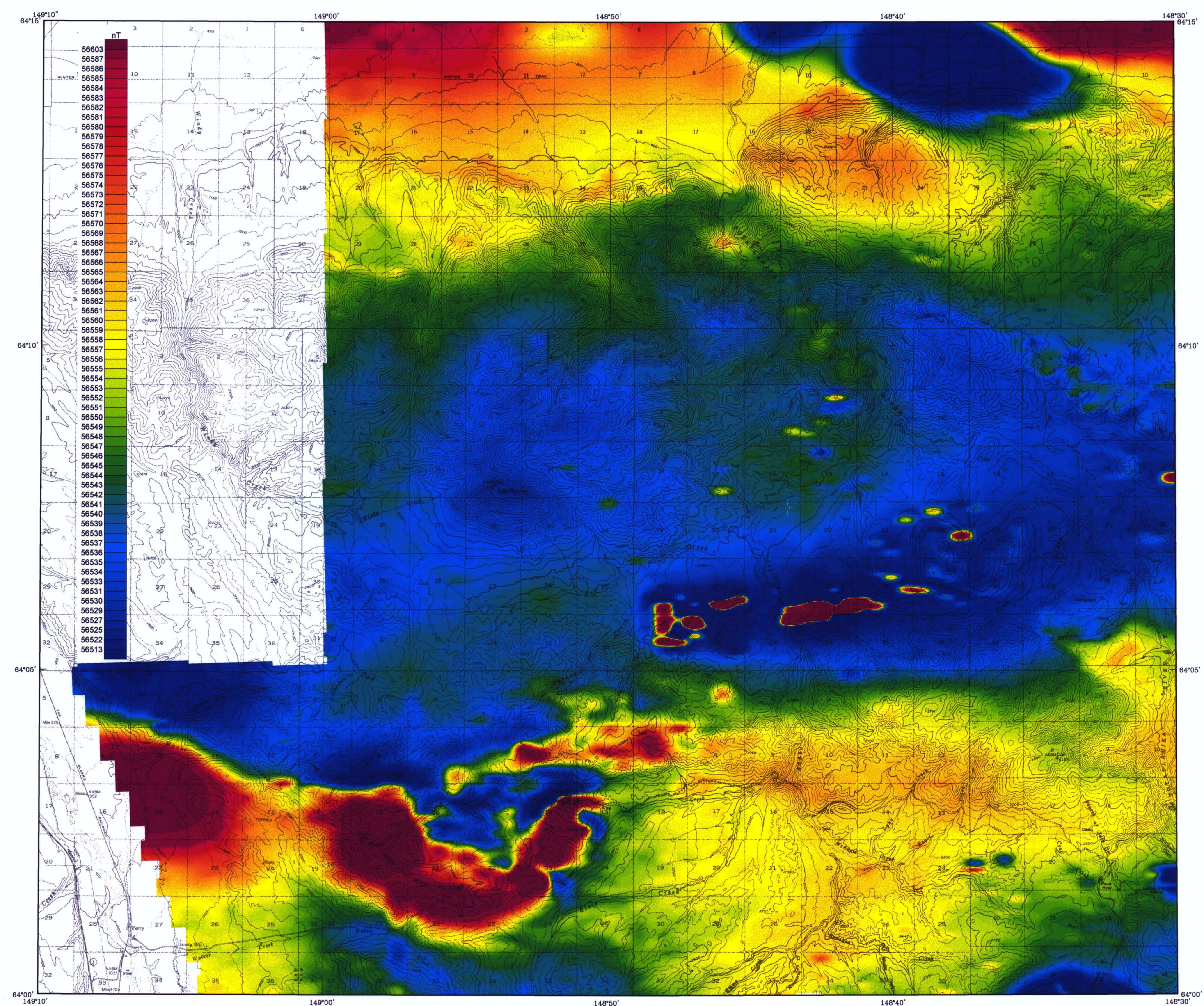

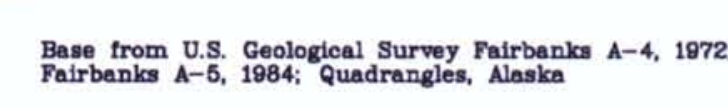
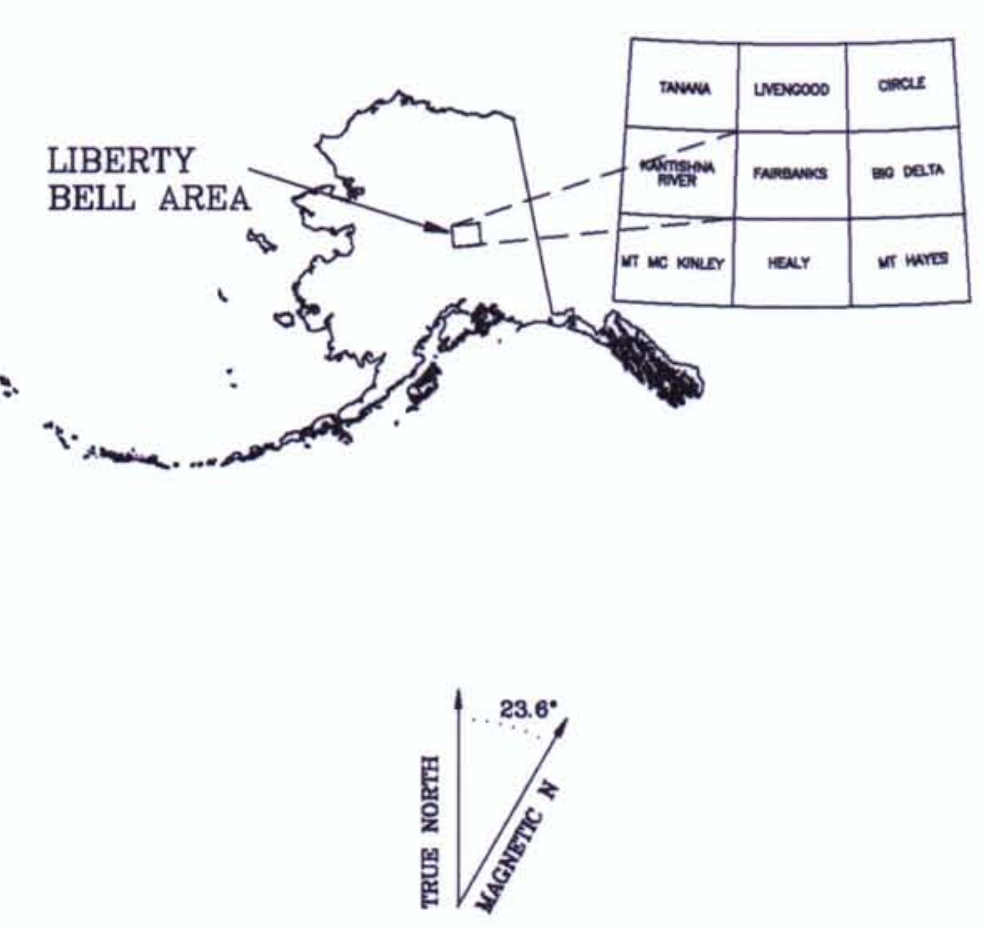

APPRoXnAATR MEAN

DESCRIPTIVE NOTES

The geophysical deto were ocquired win

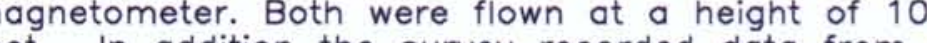

system, $50 / 60$ H

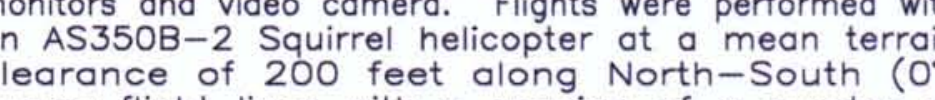

(t)

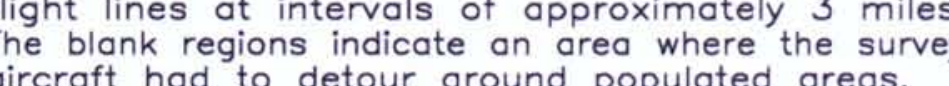

An Ashtech GG24 NAVSTAR / GLONASS Globo using post-flight differential positioning to

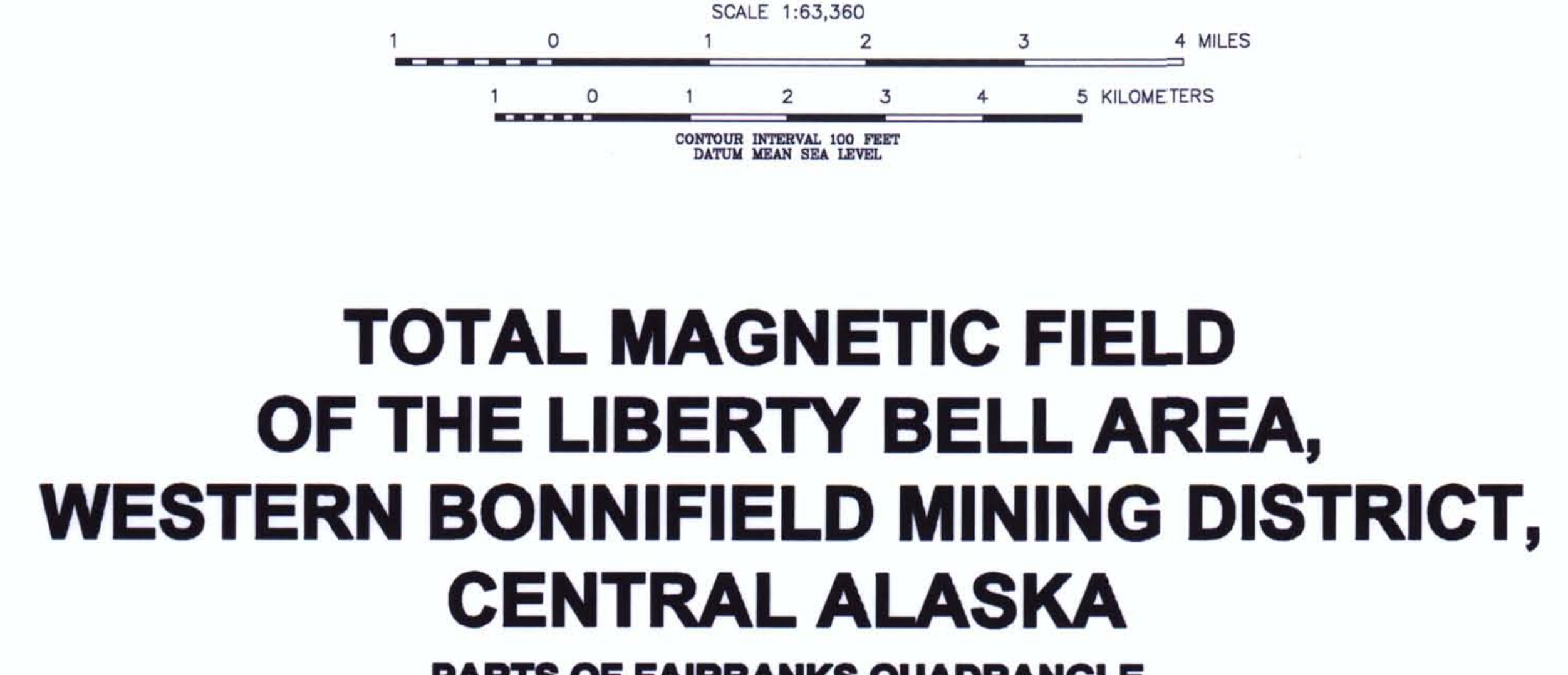

PARTS OF FAIRBANKS QUADRANGLE

2002

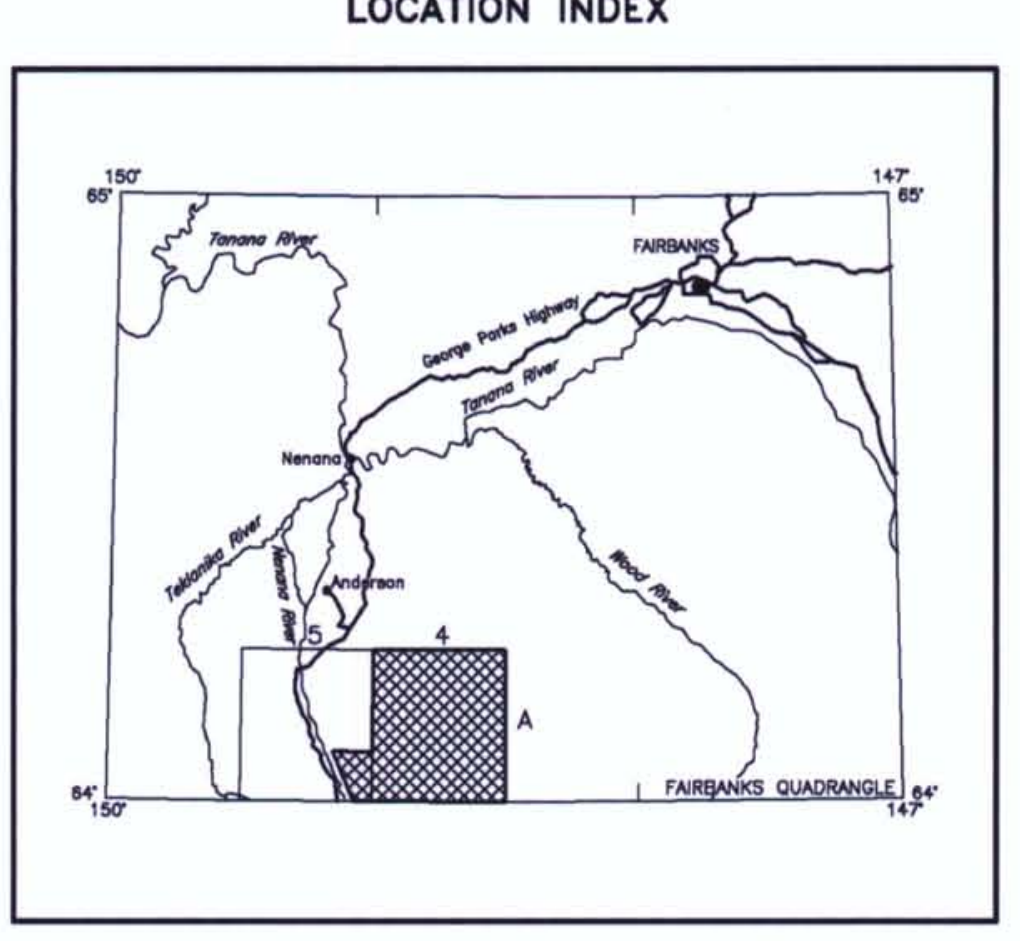

SURVEY HISTORY

between the Stote of Alaska, Department of Noturac Resources, Division of Geological \& Geophysical Surveys
(DGGS), and Stevens Exploration Mangement Corp.
Airborne geophysical dato for the area were ocquired Airborne geophysical dota tor the are were ocquired
ond processed by Fugro Airborne Surveys in 2001 .
Lourel Burns was the contract manoger for DGGS. This mop ond other products from this survey ore aviliable
by mail order or in person from DoGS., 994 University Ave.,
Suite 200, Foirbonks, Alasko, 99709.

TOTAL MAGNETIC FIELD

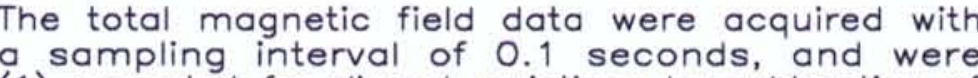
the digitally recorded bose station mognetic dato

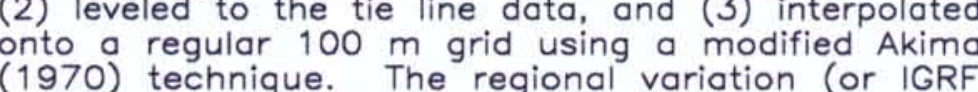
grodient, 2000 , updated to August, 2001 ) wos removed

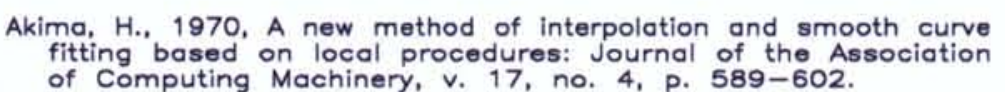




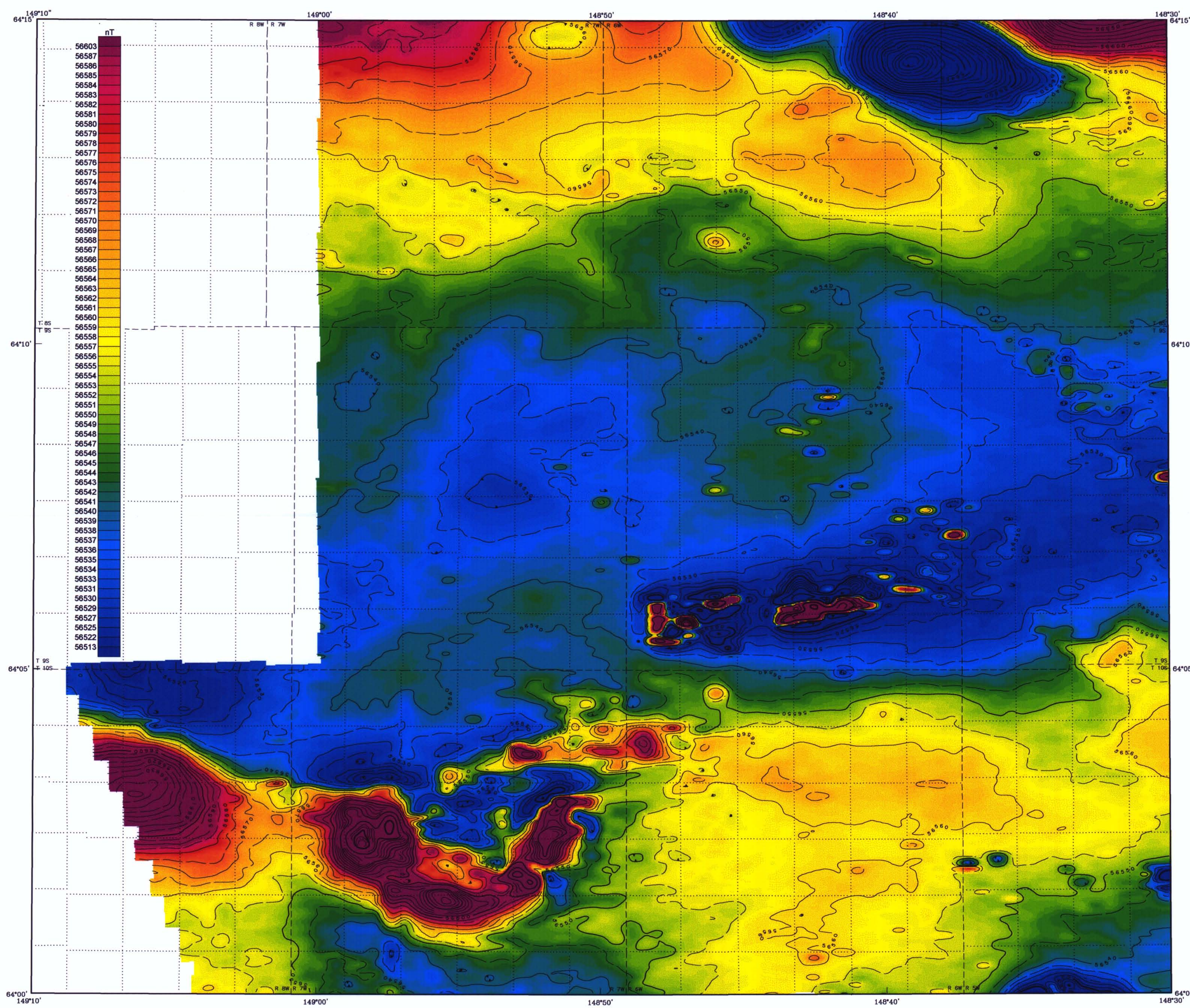

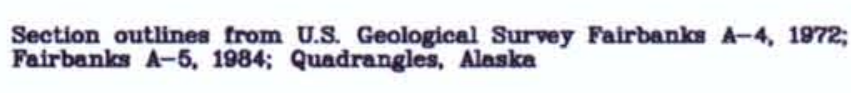

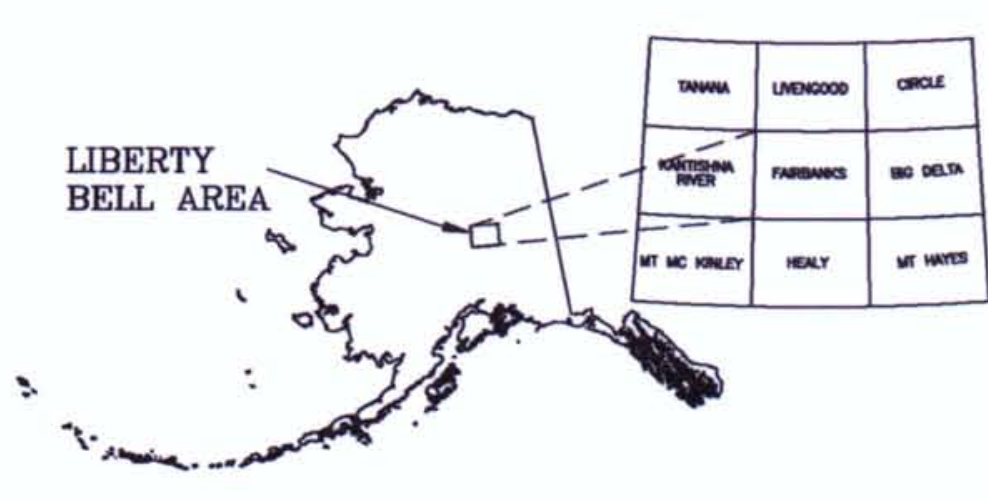

DESCRIPTIVE NOTES

The geophysical data were acquired with a DIGHEM magnetometer. Both were flown at a height of 100 radar altimeter, GPS navigation system, $50 / 60$ H AS $350 B-2$ Squirrel helicopter at a mean terr ines with ols aircraft had to detour around populated areas. An Ashtech GG24 NAVSTAR / GLONASS Global position was derived every 0.5 secon

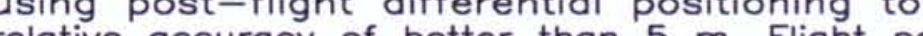
Positions were projected onto the Clarke
(UTM zone 6) spheroid, 1927 North American datum
using a central meridian (CM) of 147, a north constant of 0 and an east constant of 500,000 .
Positional accuracy of the presented dato is better

TOTAL MAGNETIC FIELD

The total magnetic field data were acquired with
a sampling interval of 0.1 seconds, and were (2) leveled to the tie line data, and (3) interpolated
onto a regular $100 \mathrm{~m}$ grid using a modified Akima (1970) technique. The regionol variation (or IIIRF
gradient, 2000, updated to August, 2001) was removed

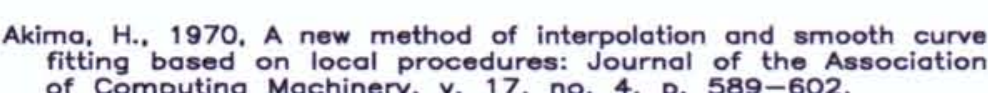

TOTAL MAGNETIC FIELD OF THE LIBERTY BELL AREA, WESTERN BONNIFIELD MINING DISTRICT, CENTRAL ALASKA PARTS OF FAIRBANKS QUADRANGLE 2002

This map has been compliled and drown under contrac
between the State of Alaska, Department of Notura Resources, Division of Geological \& Geophysical Survey
(DGGS), and Stevens Exploration Management Corp And
and processed by t Fugro Airborne Surveys in 2001.

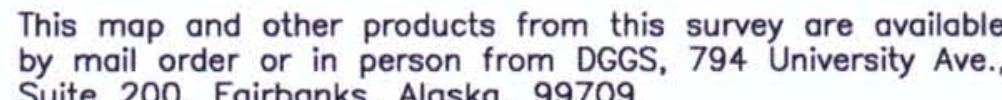

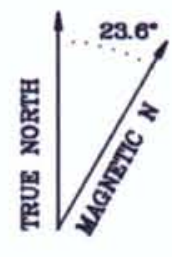

APPROXXATER MEAA

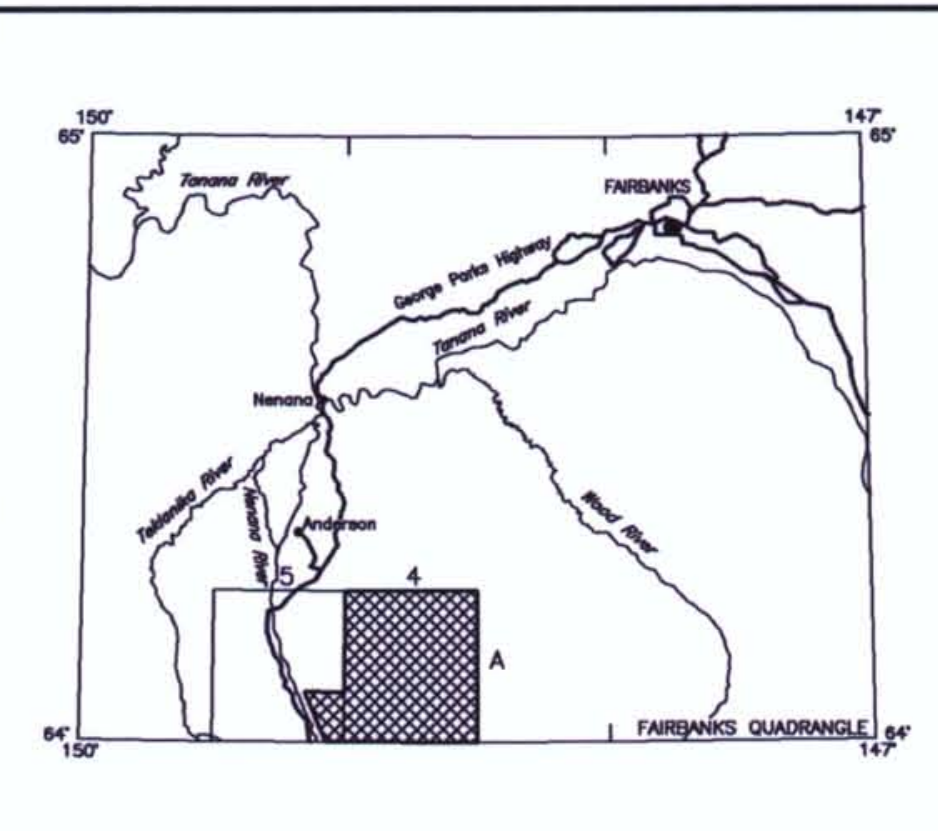

MAGNETIC CONTOUR INTERVAL 


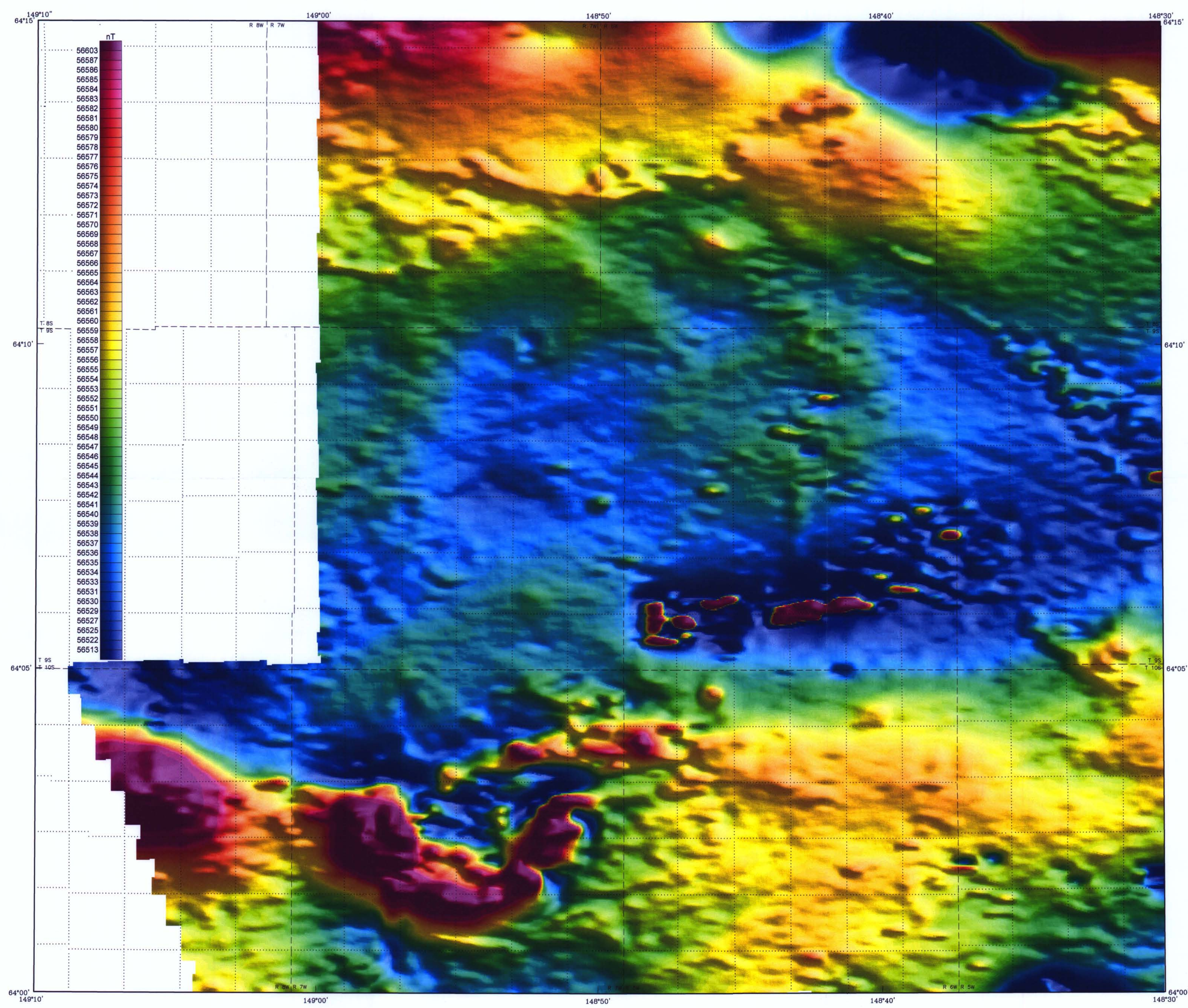

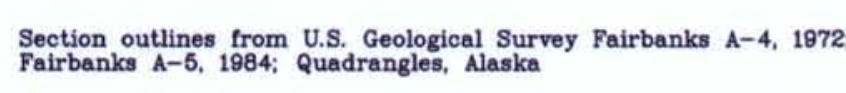

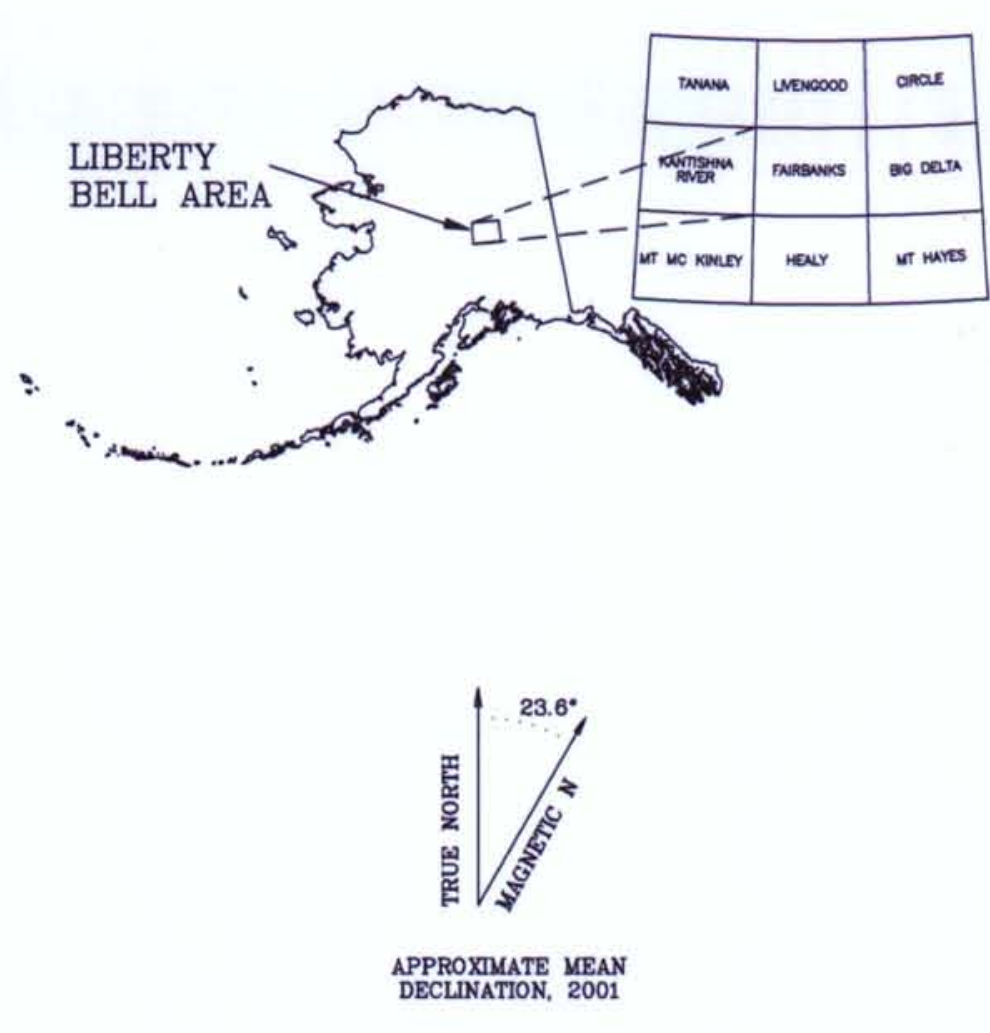

DESCRIPTIVE NOTES

The geophysical dato were acquired with o DIGHEM
Electromagnetic (EM) system and a Scintrex cesium

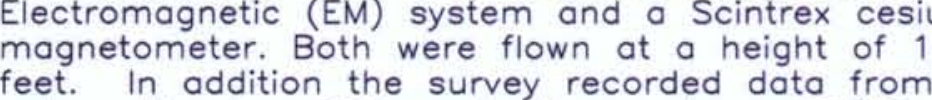

rador attimeter, GPS navigation system, 50/60

The blank regions indicate on areo where the surve
aircraft had to detour around populated areas.

COLOR SHADOW TOTAL MAGNETIC FIELD OF THE LIBERTY BELL AREA, WESTERN BONNIFIELD MINING DISTRICT, CENTRAL ALASKA

PARTS OF FAIRBANKS QUADRANGLE 2002

Sun Azimuth: 45 degrees

Sun Inclination: 35 degrees
LOCATION INDEX

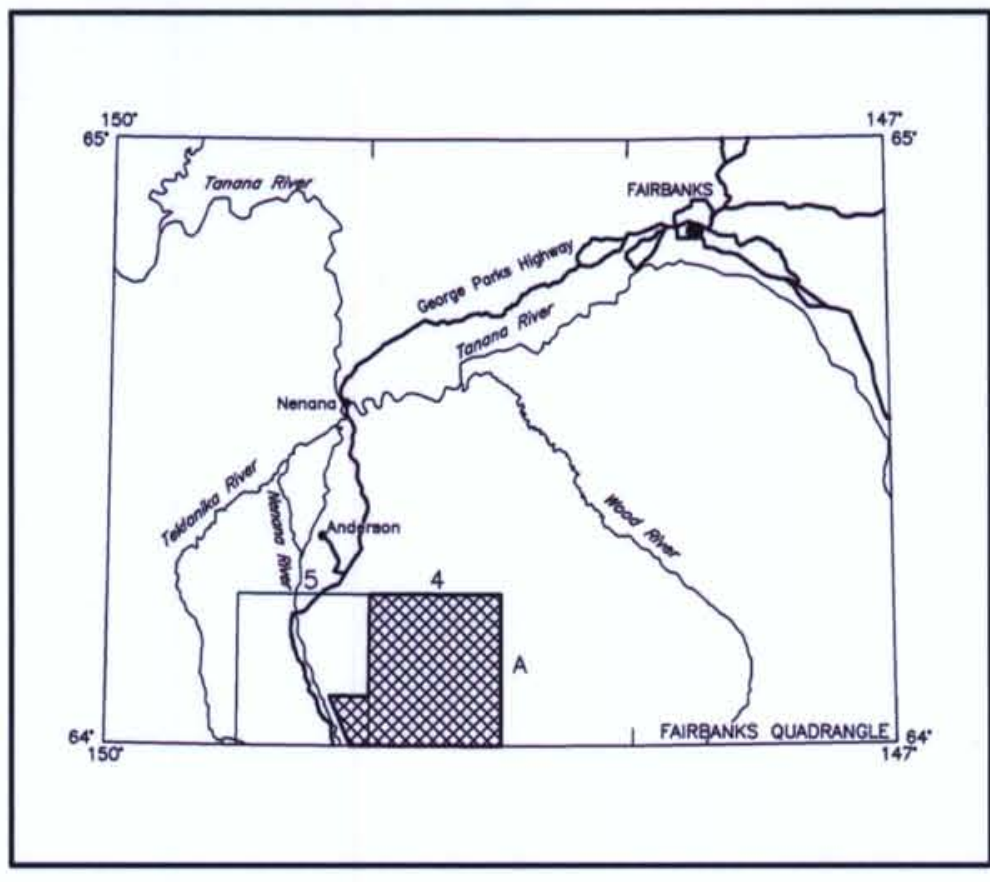

SURVEY HISTORY

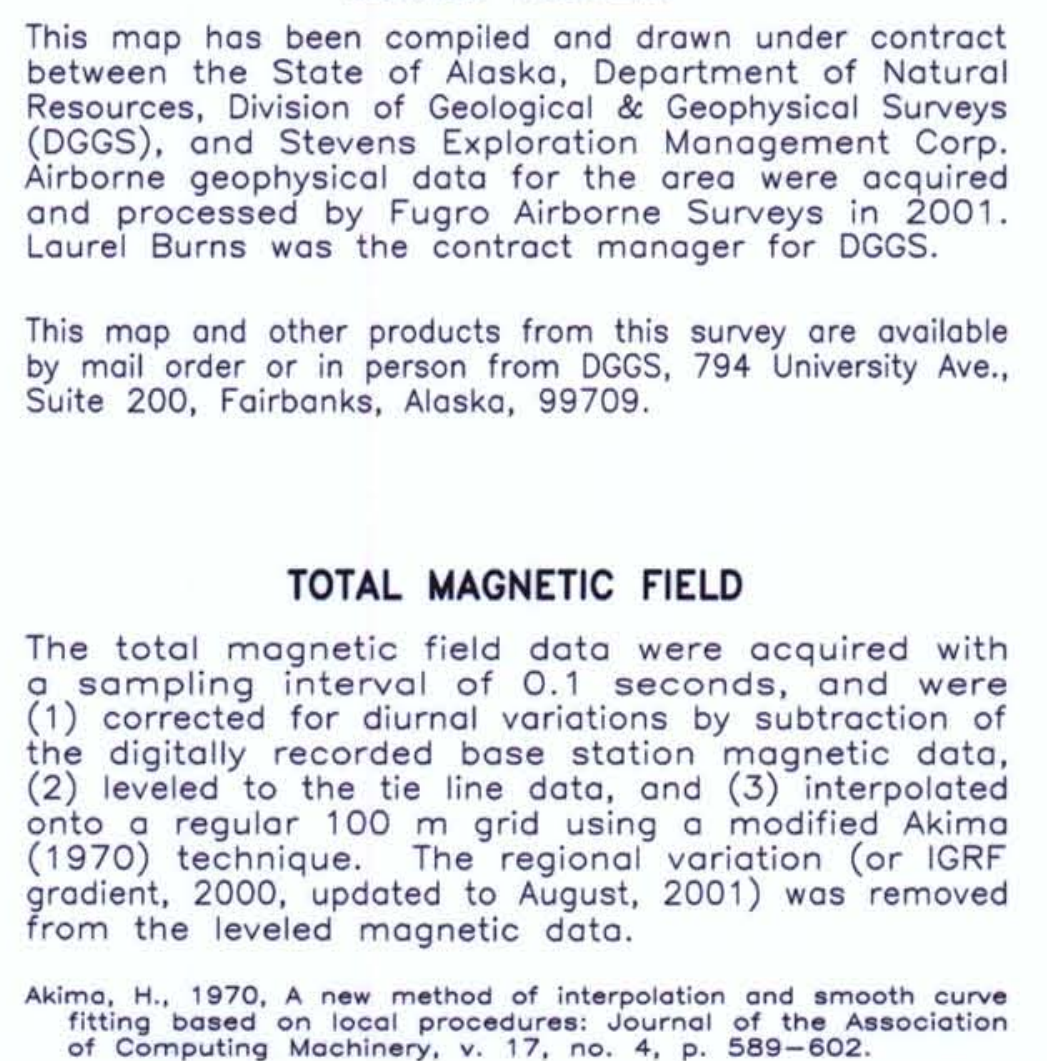




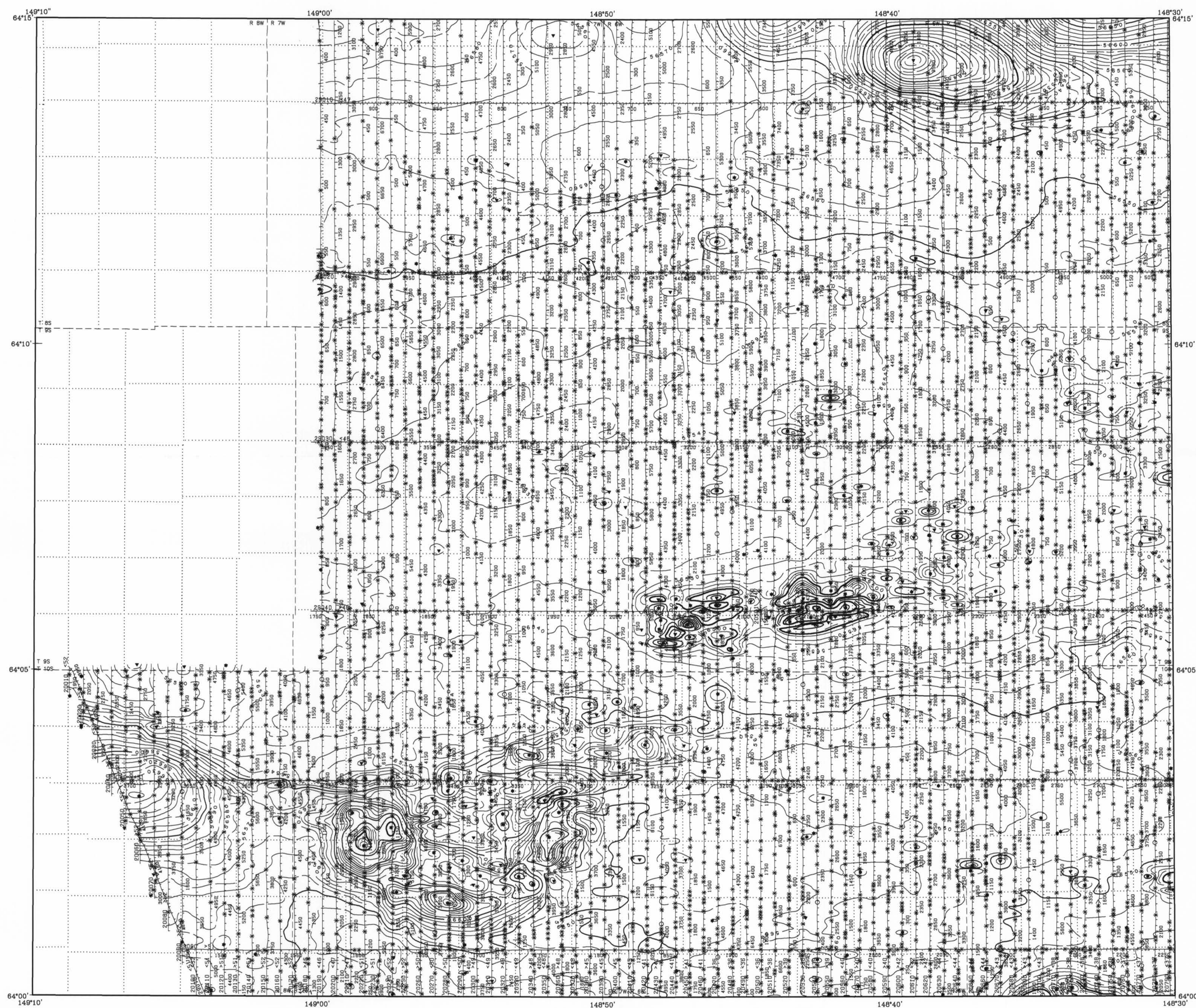

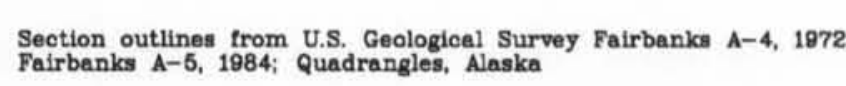

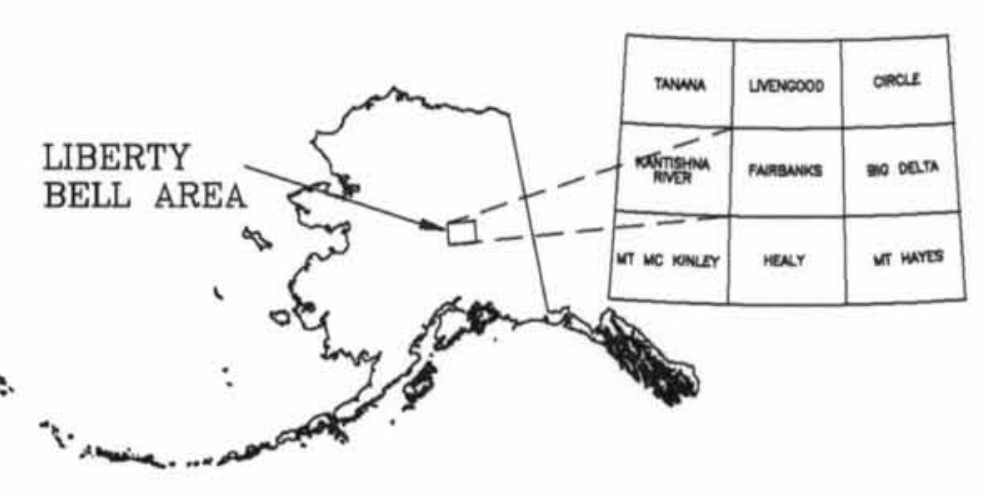

DESCRIPTIVE NOTES

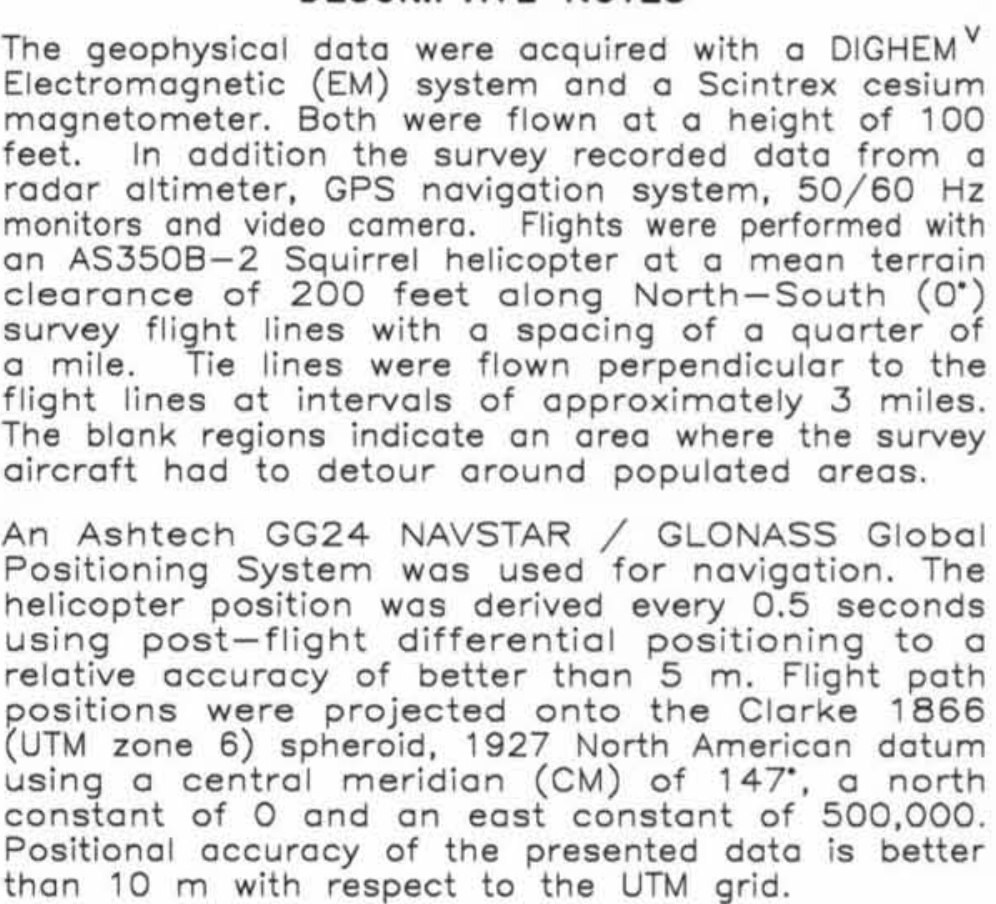

ELECTROMAGNETICS
TOTAL MAGNETIC FIELD AND ELECTROMAGNETIC ANOMALIES OF THE LIBERTY BELL AREA, WESTERN BONNIFIELD MINING DISTRICT, CENTRAL ALASKA PARTS OF FAIRBANKS QUADRANGLE 2002
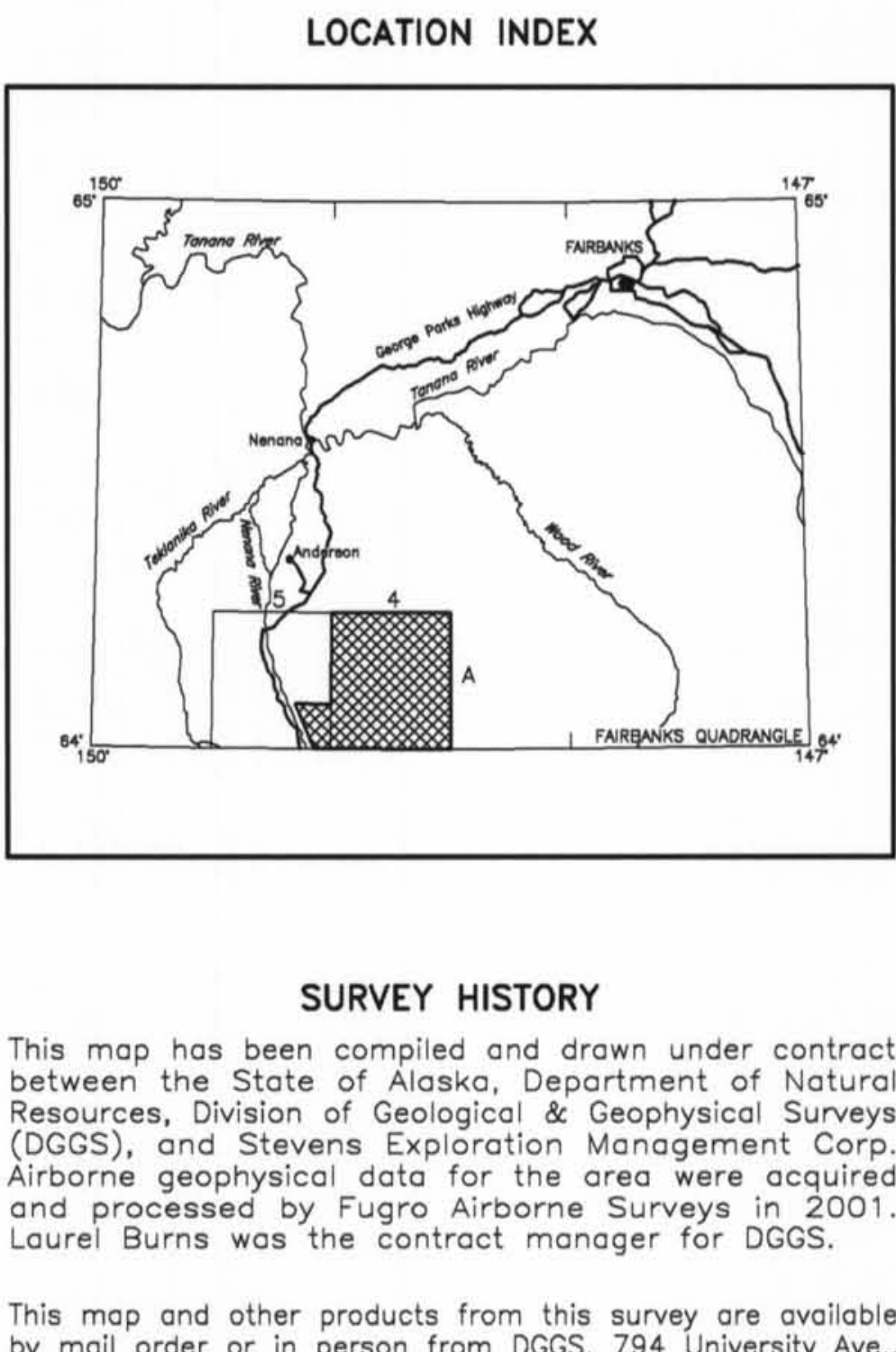

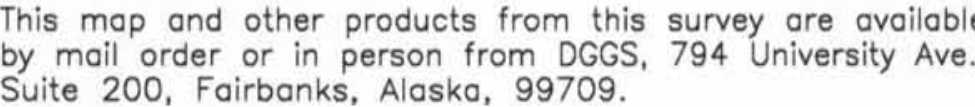

MAGNETIC CONTOUR INTERVAL

TOTAL MAGNETIC FIELD

ELECTROMAGNETIC ANOMALIES

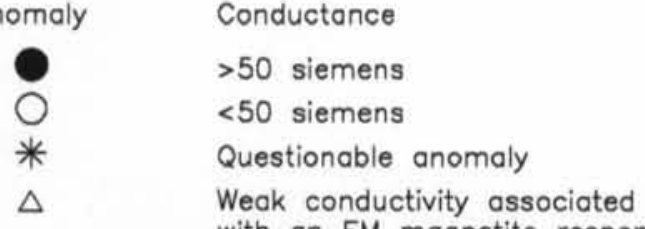



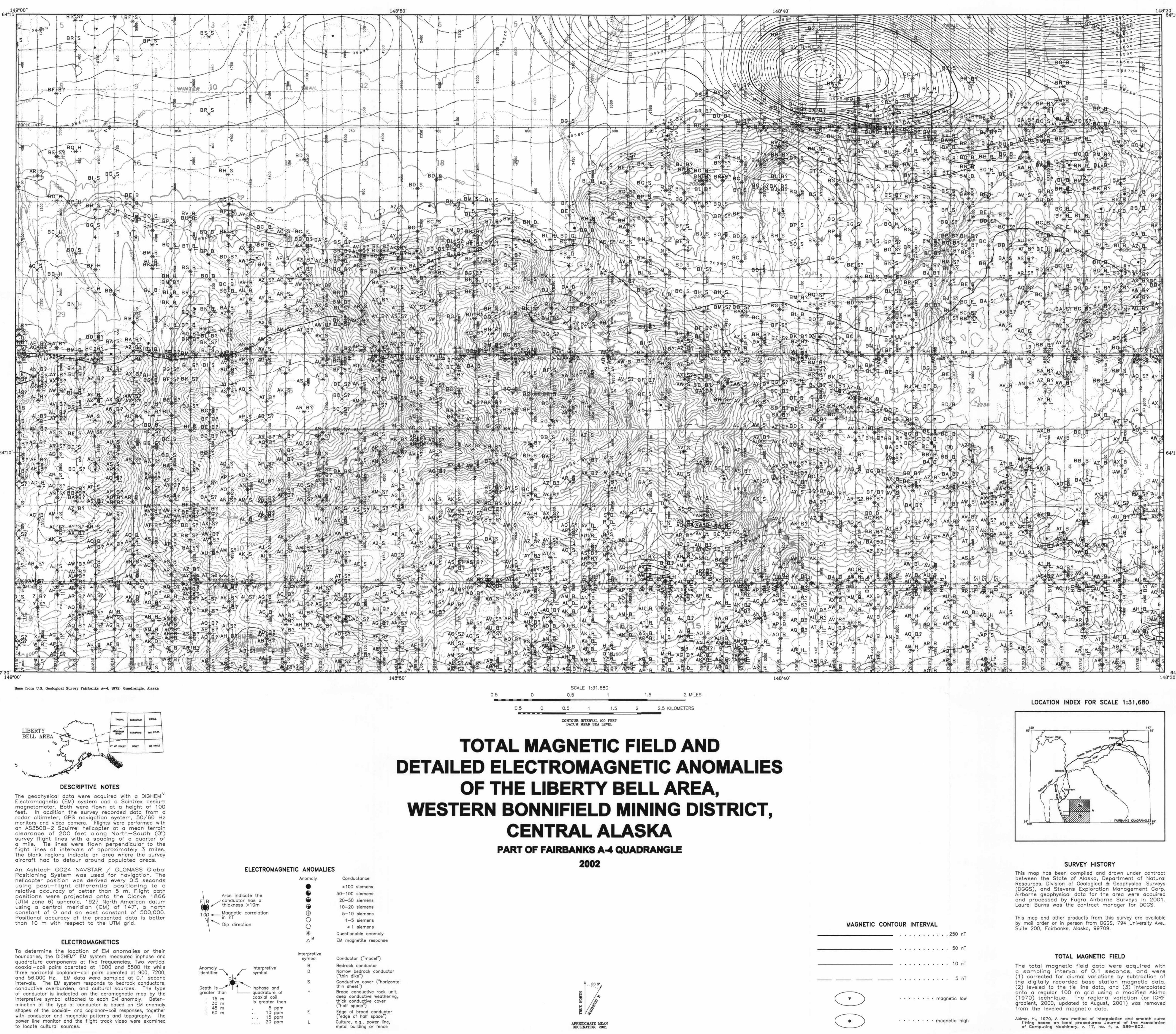
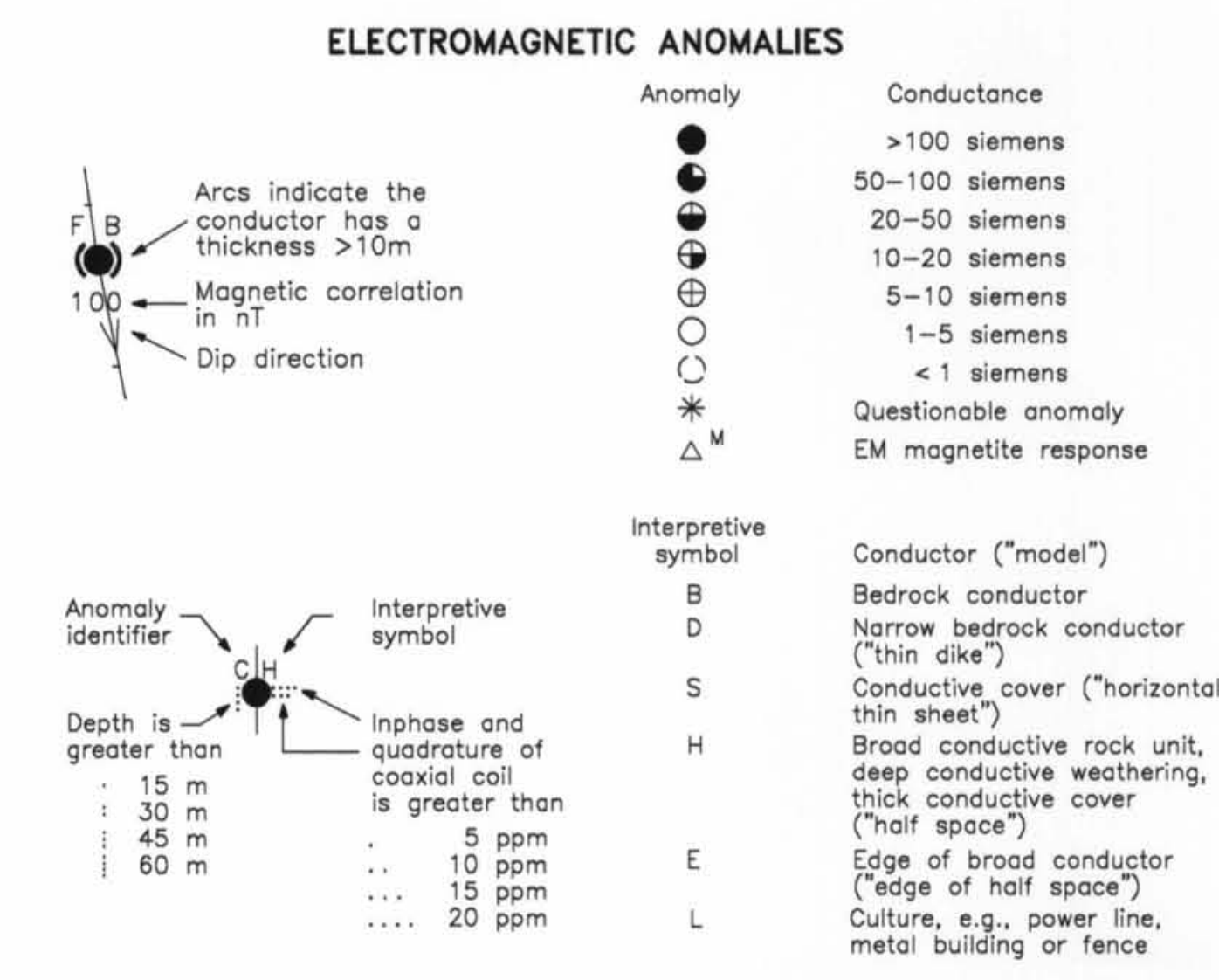

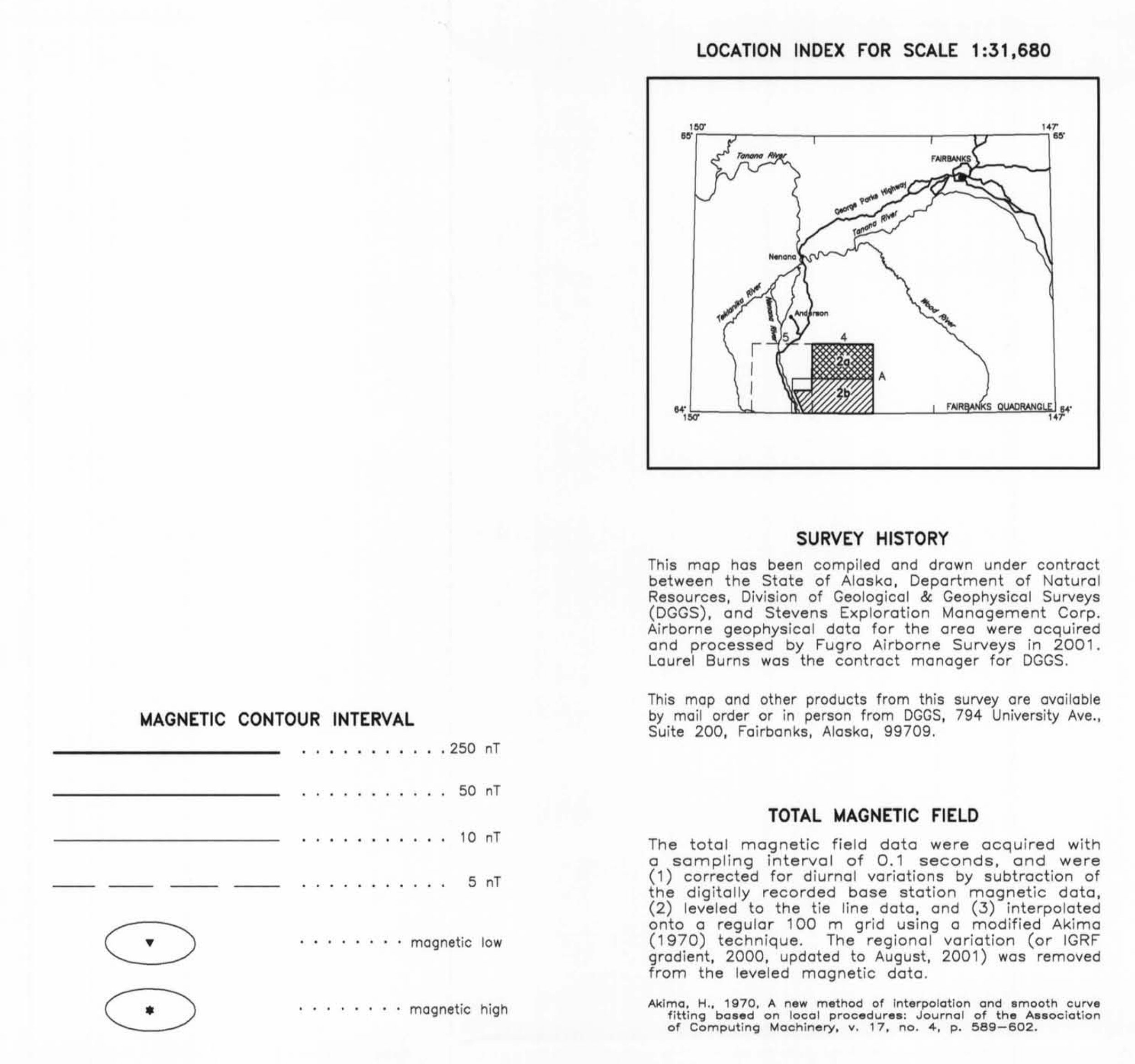

TOTAL MAGNETIC FIELD AND

OF THE LIBERTY BELL AREA,

2002

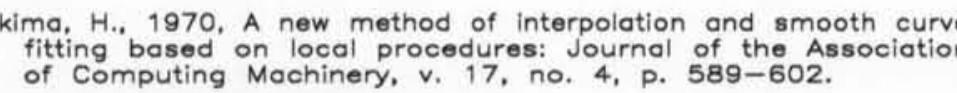




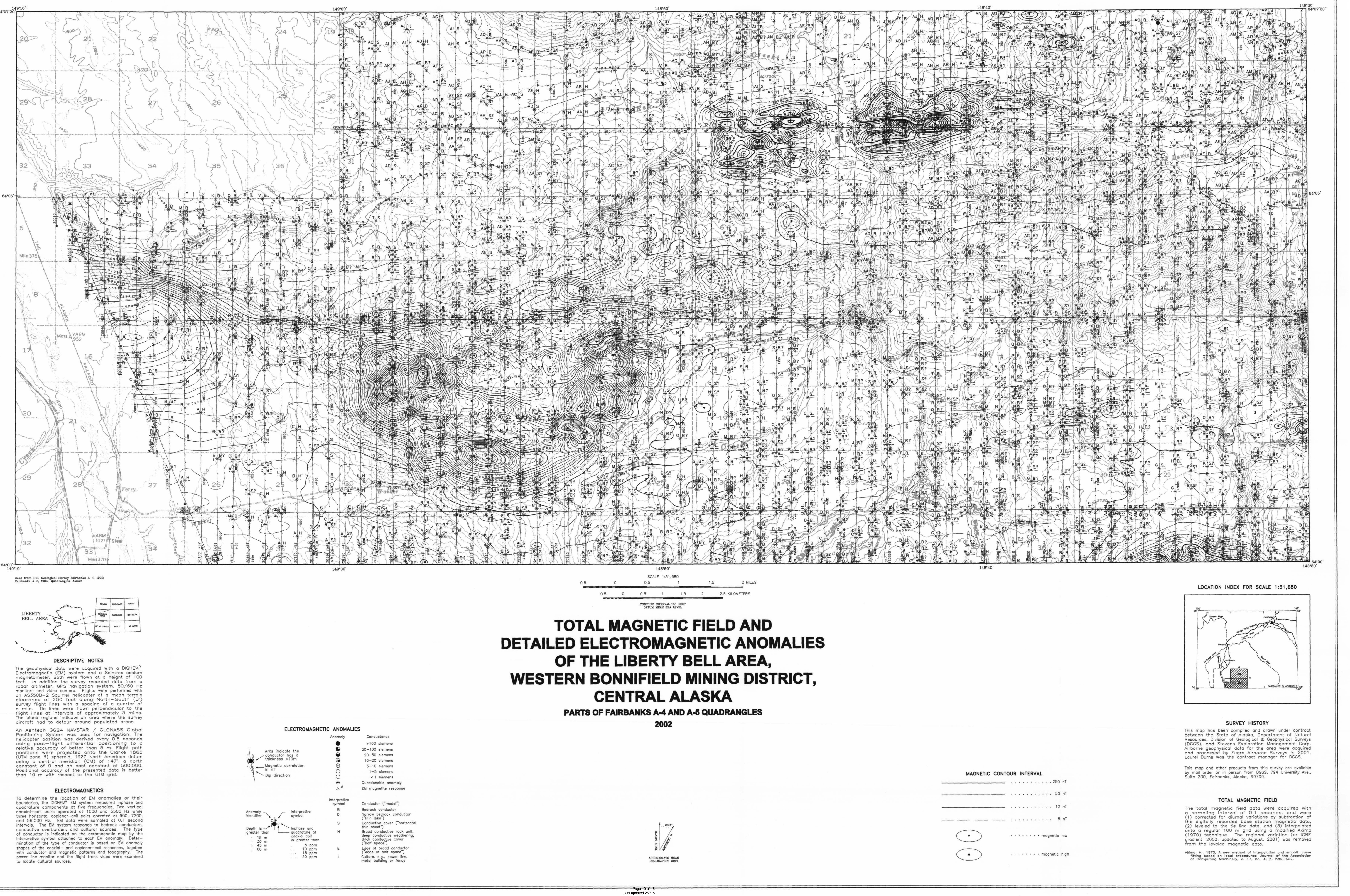




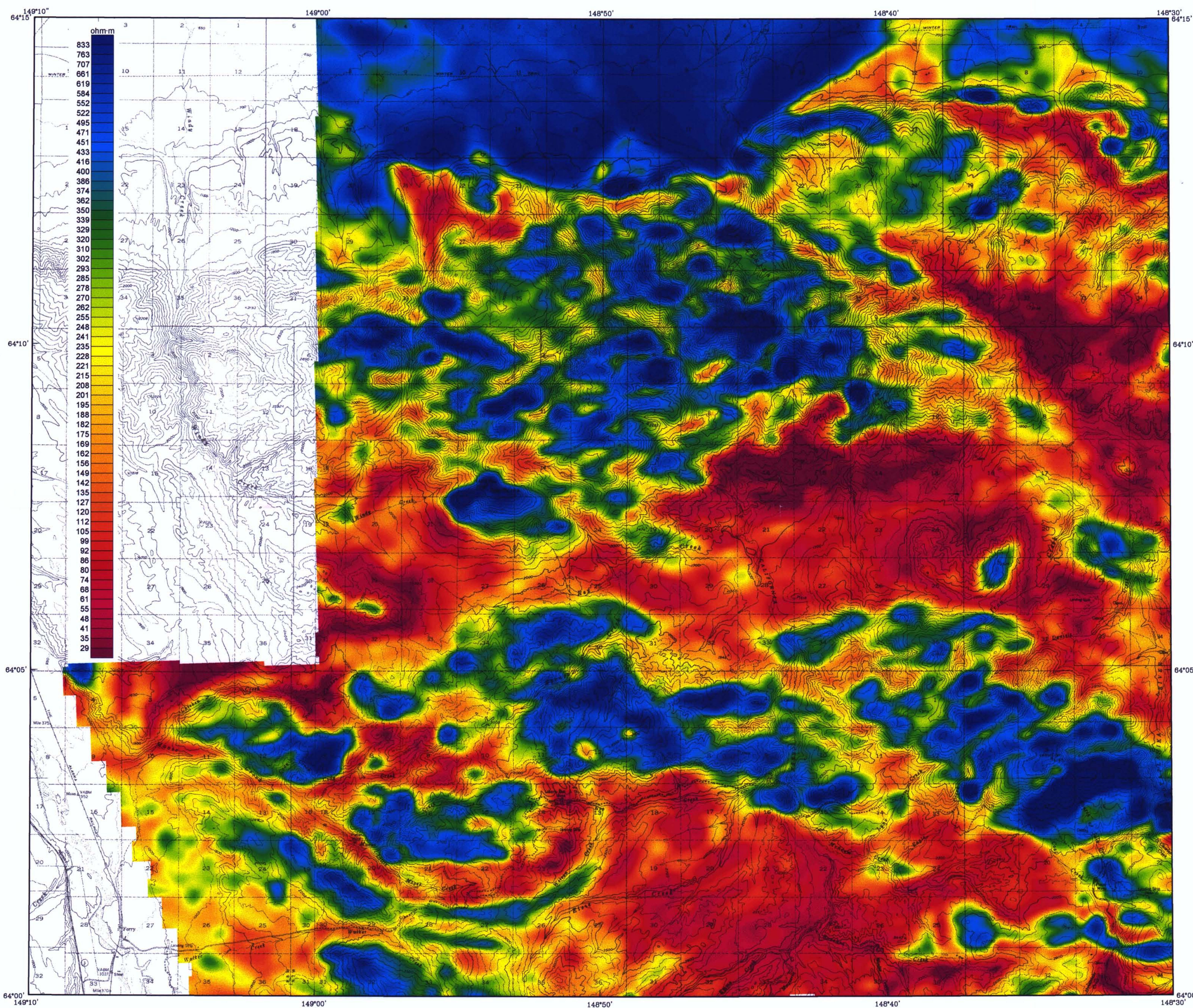

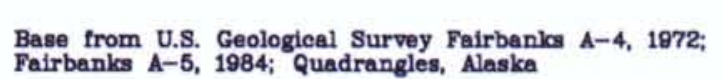
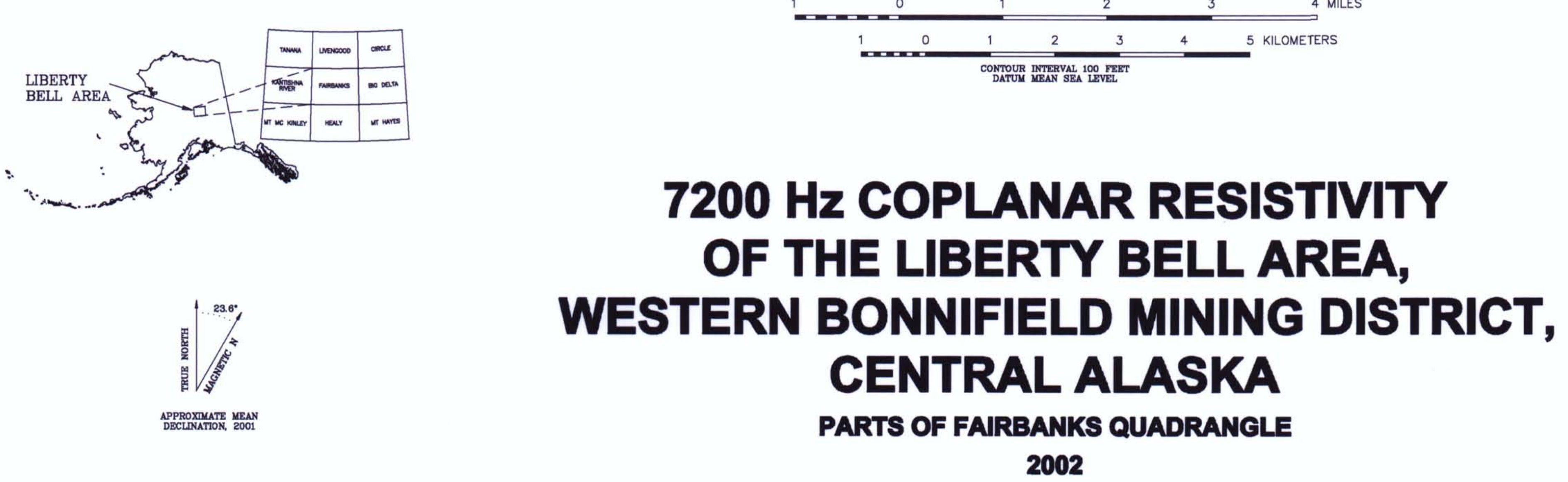

DESCRIPTIVE NOTES

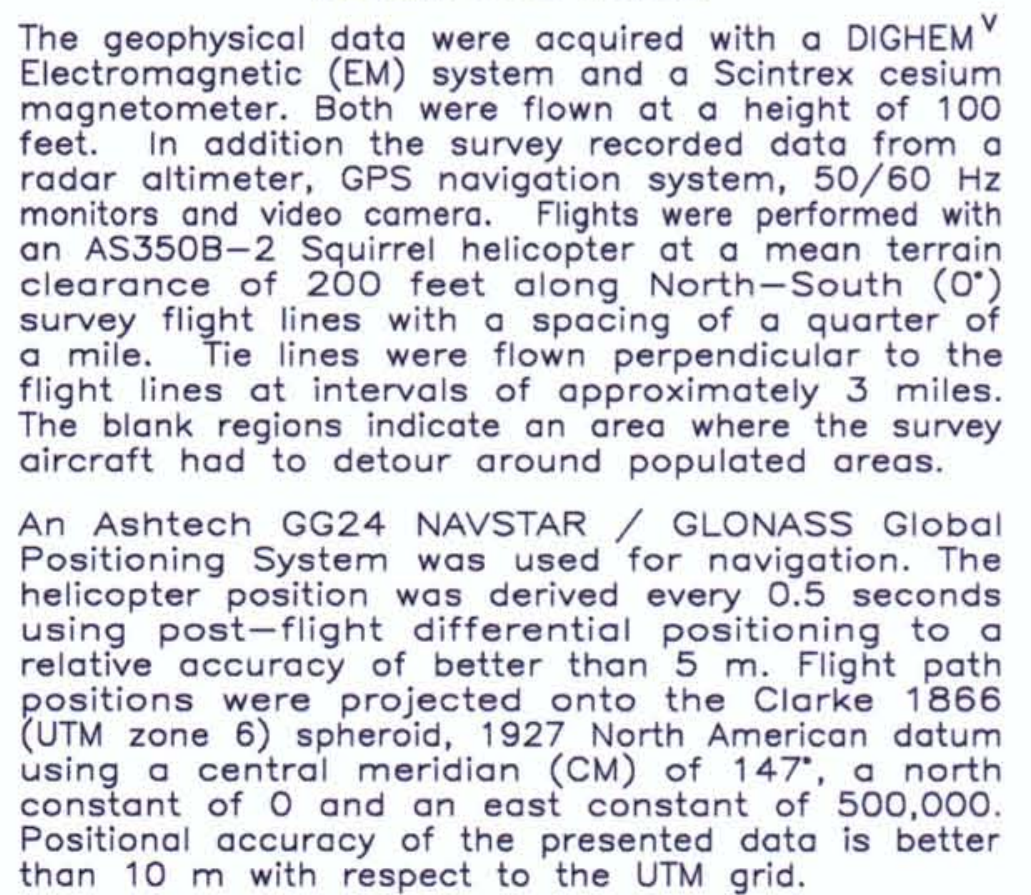

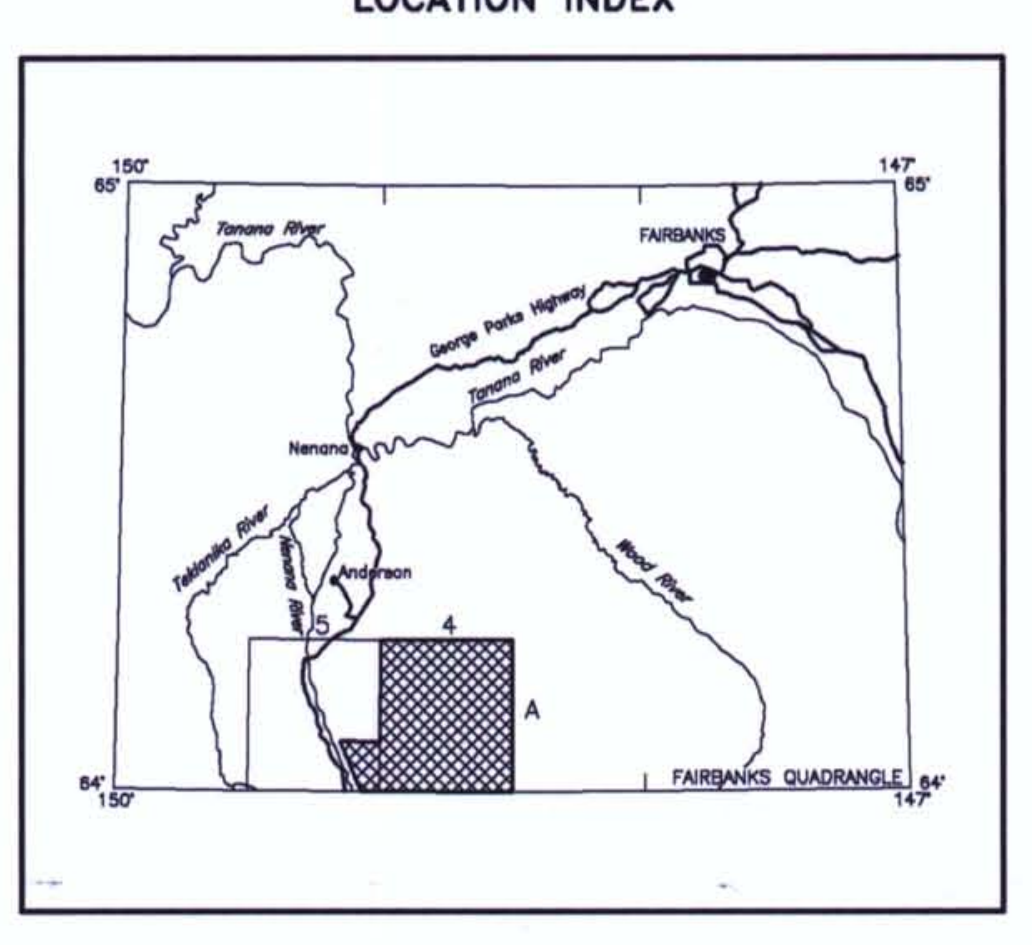

SURVEY HISTORY
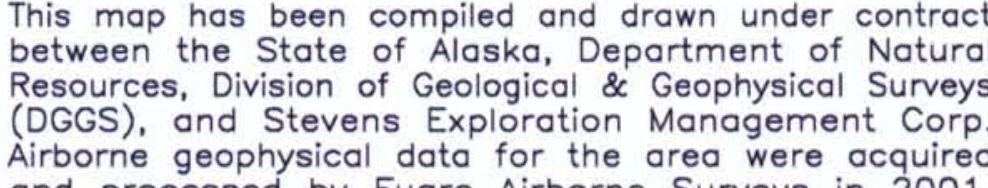

This map and other products from this survey are available

This map ond other products from this survey are avoilable
by mail order or in person from DGGS, 794 University Ave.,
Suite 200, Foirbanks, Alaska, 99709 .

RESISTIVITY

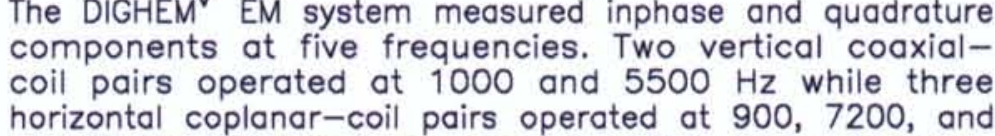

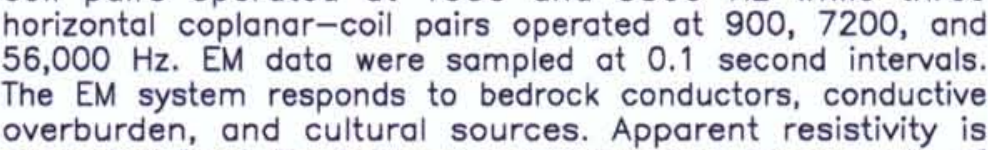

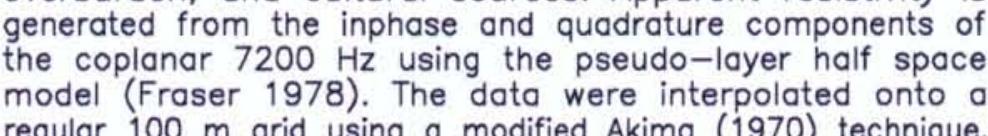

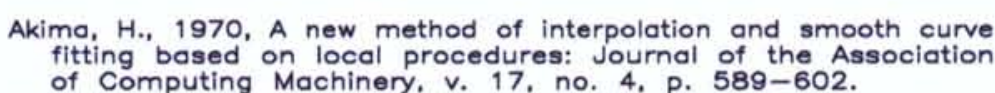

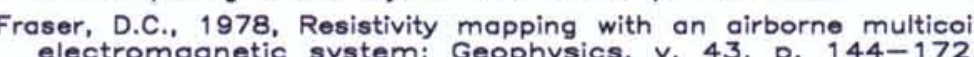




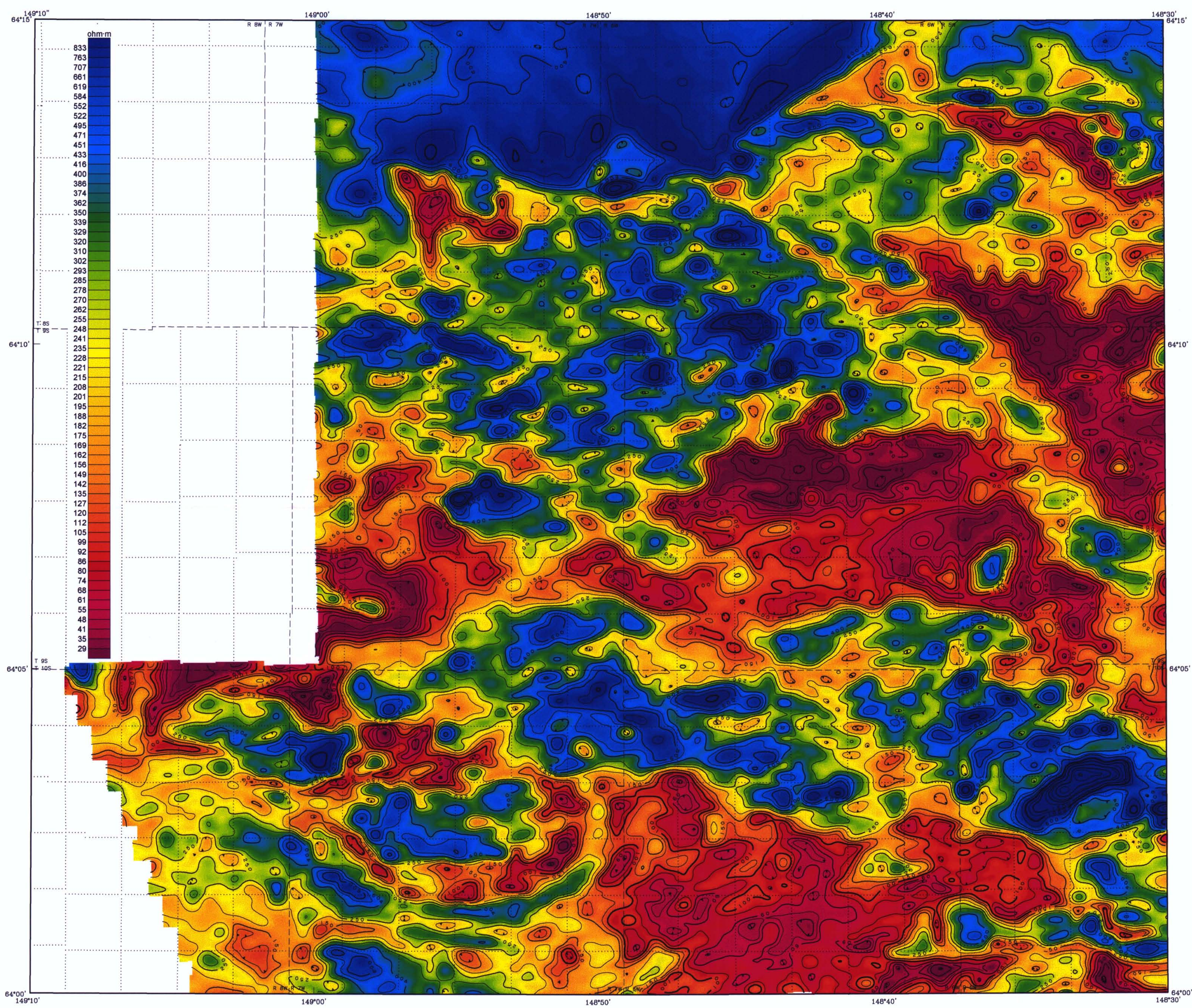

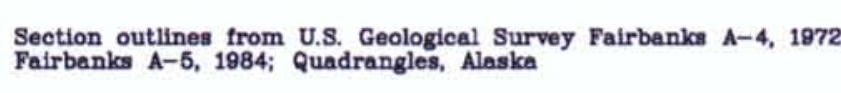

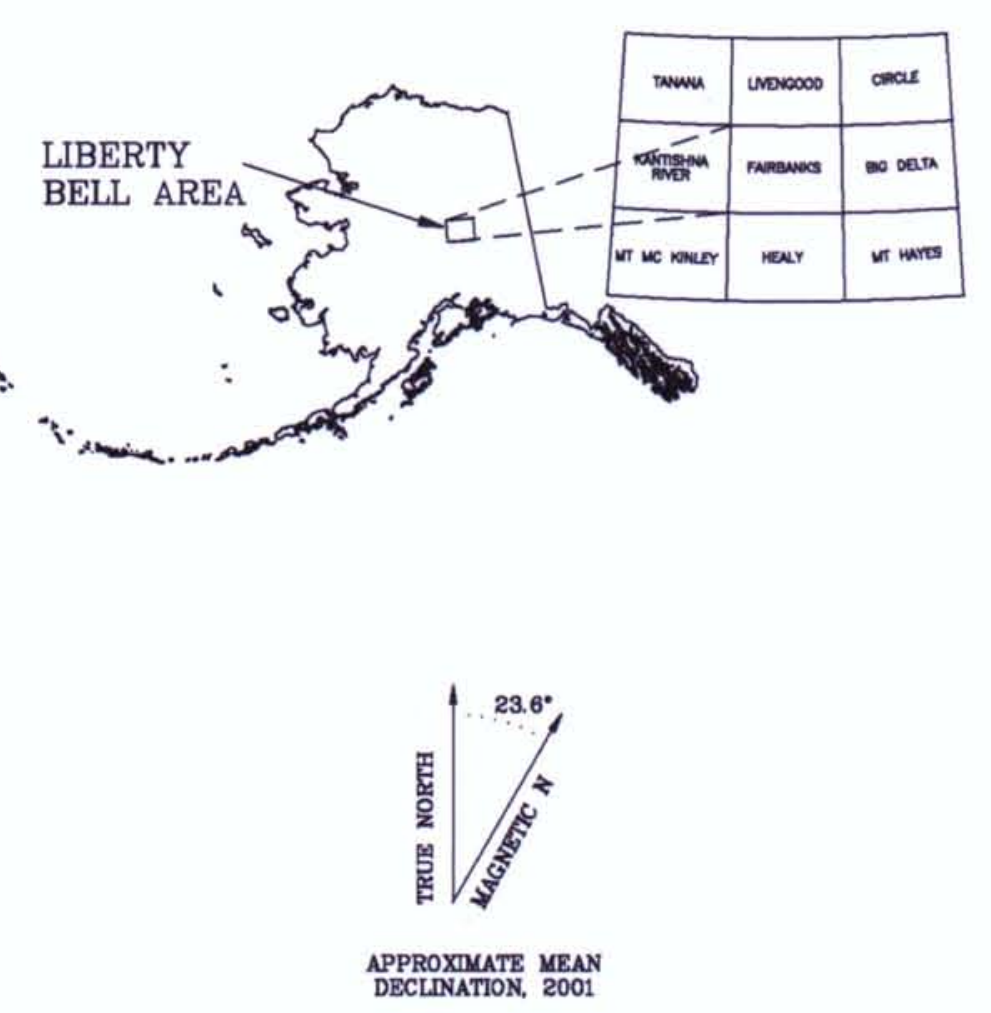

\section{$7200 \mathrm{~Hz}$ COPLANAR RESISTIVITY} OF THE LIBERTY BELL AREA, WESTERN BONNIFIELD MINING DISTRICT, CENTRAL ALASKA PARTS OF FAIRBANKS QUADRANGLE 2002

DESCRIPTIVE NOTES

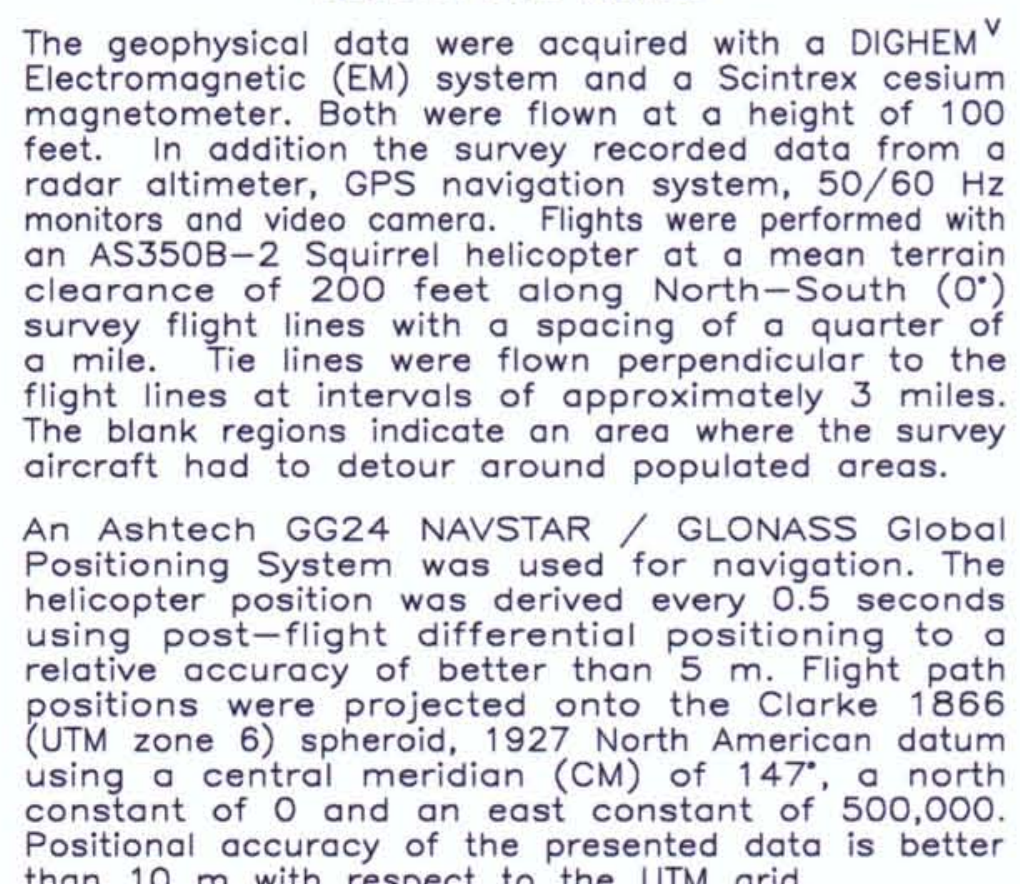

RESISTIVITY CONTOURS

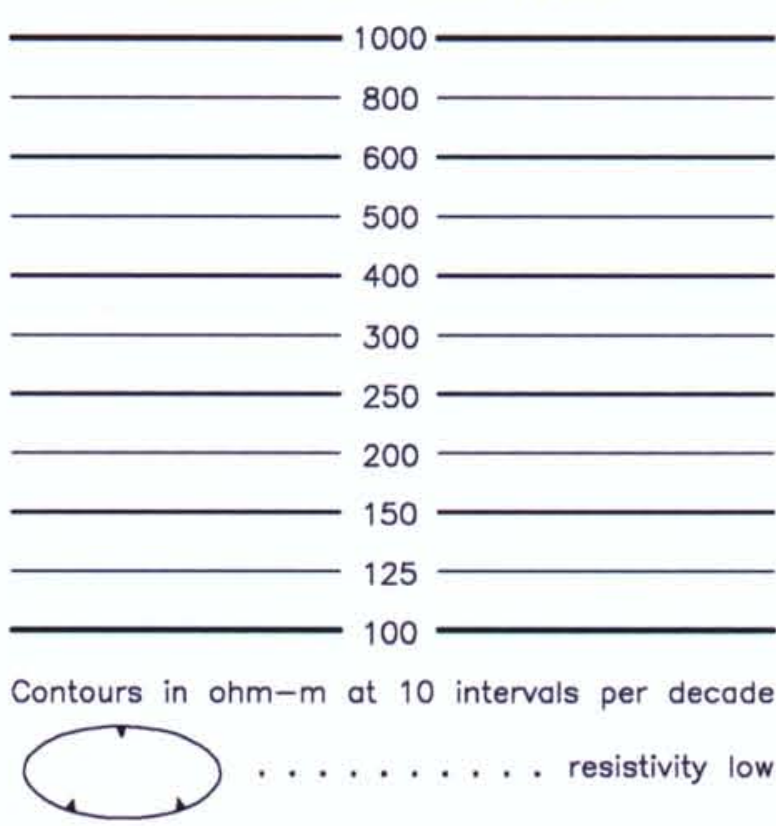

LOCATION INDEX

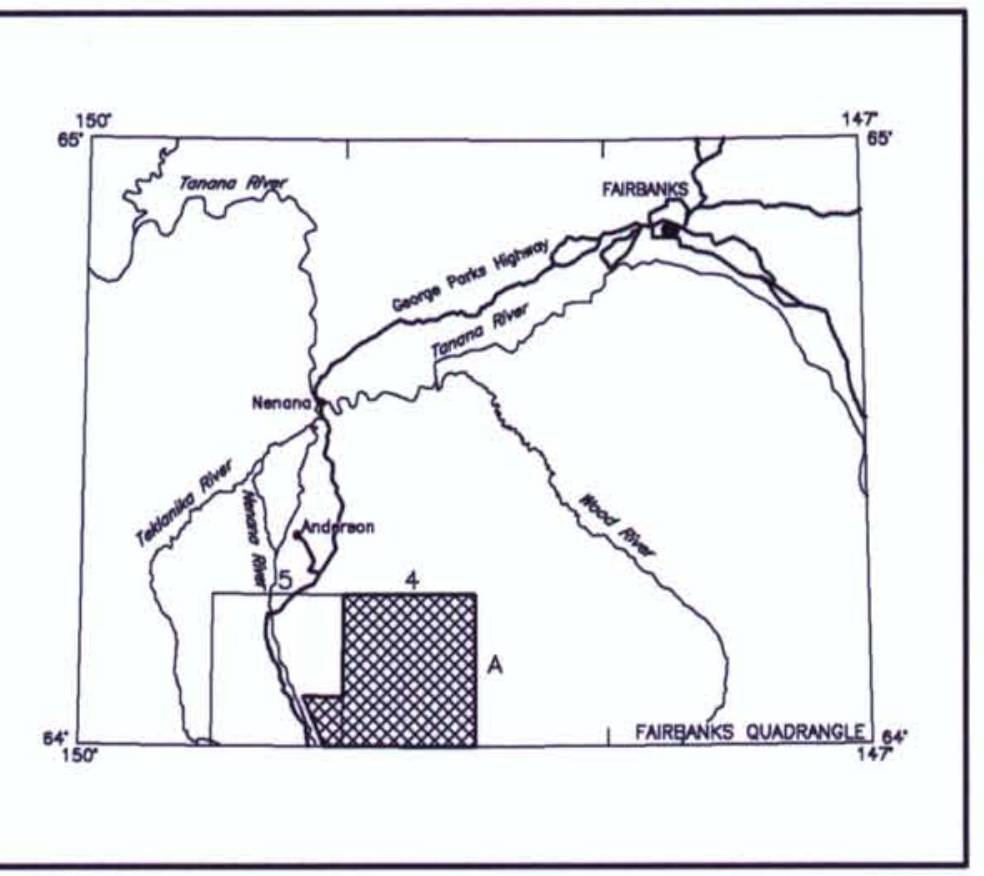

SURVEY HISTORY

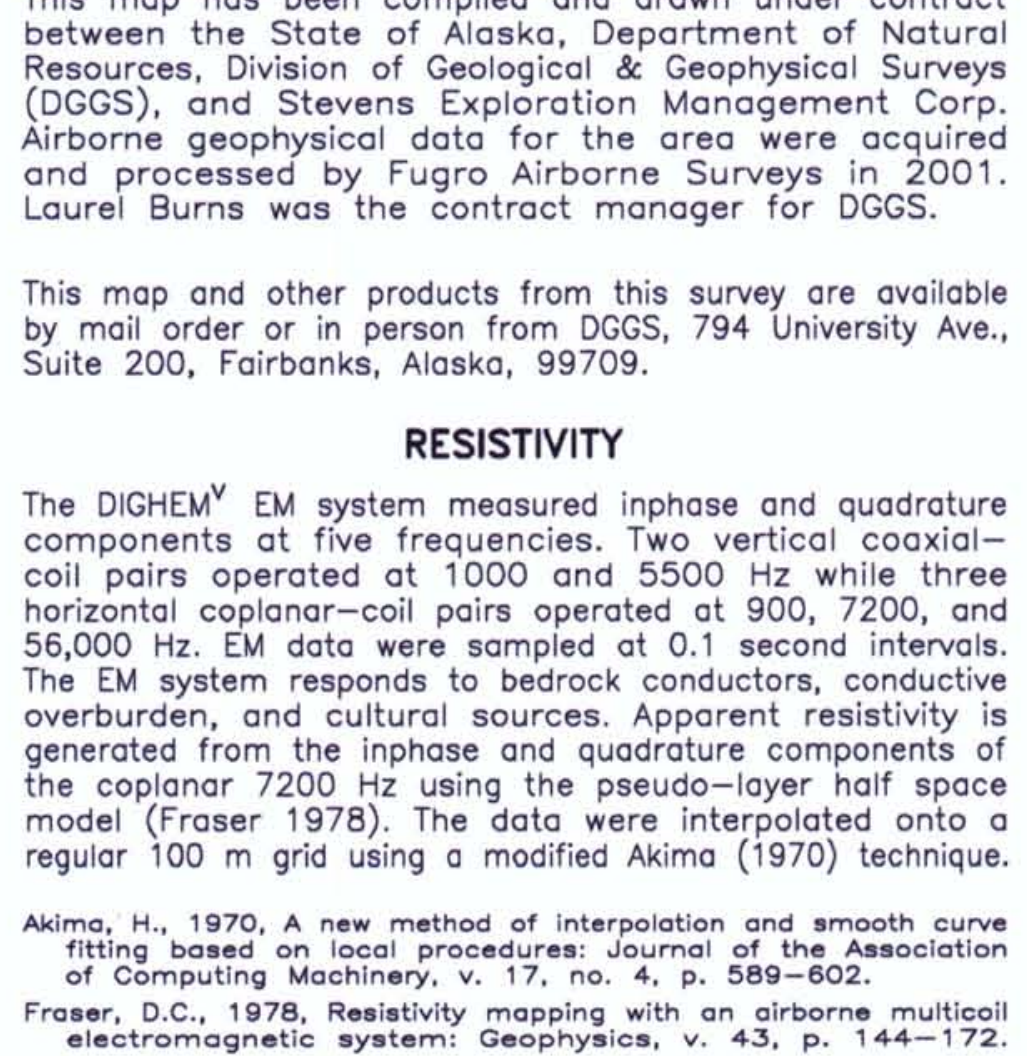




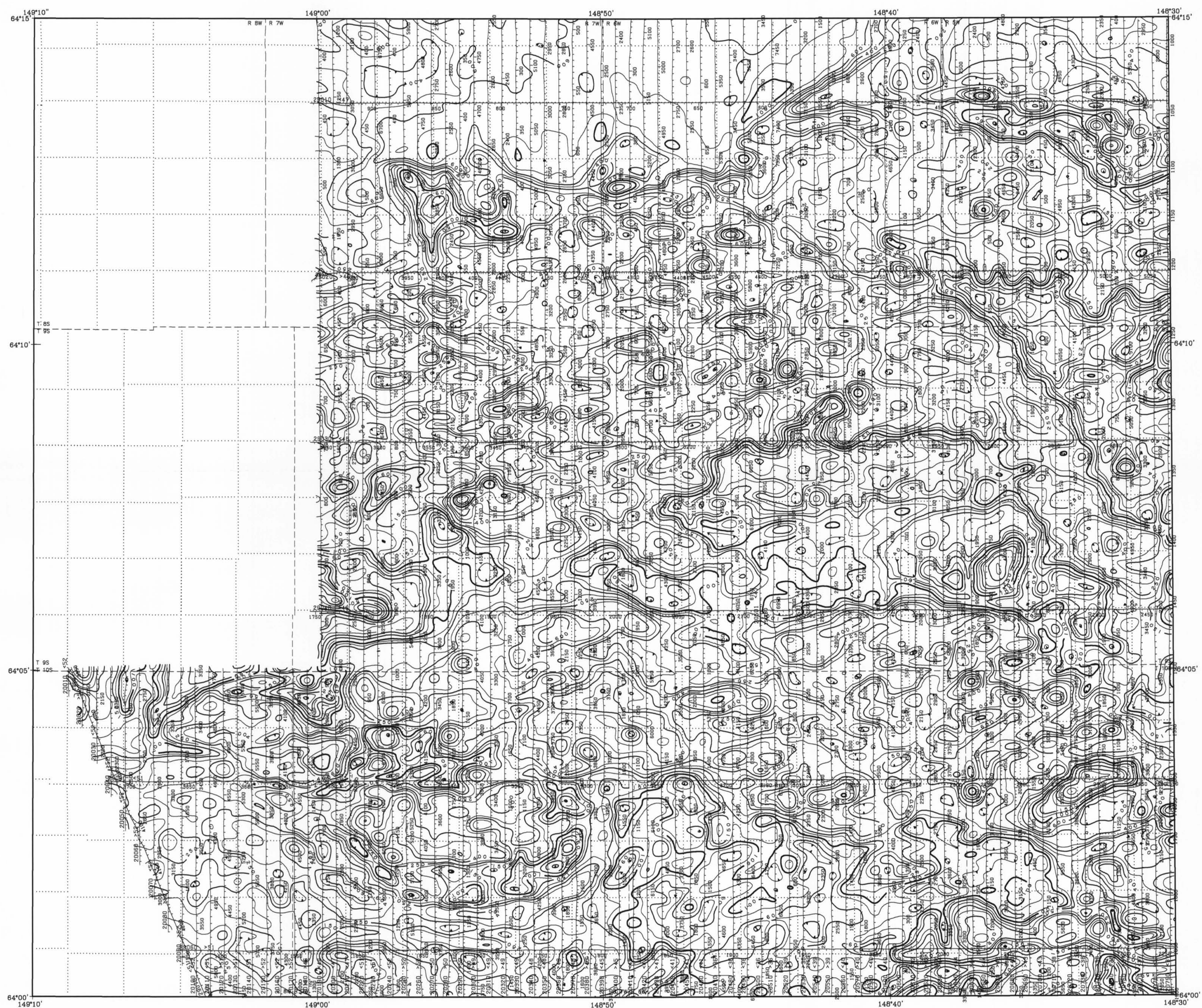

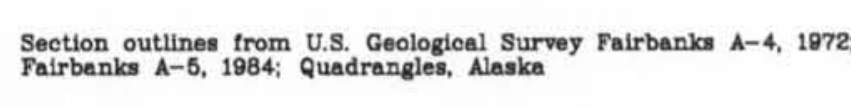

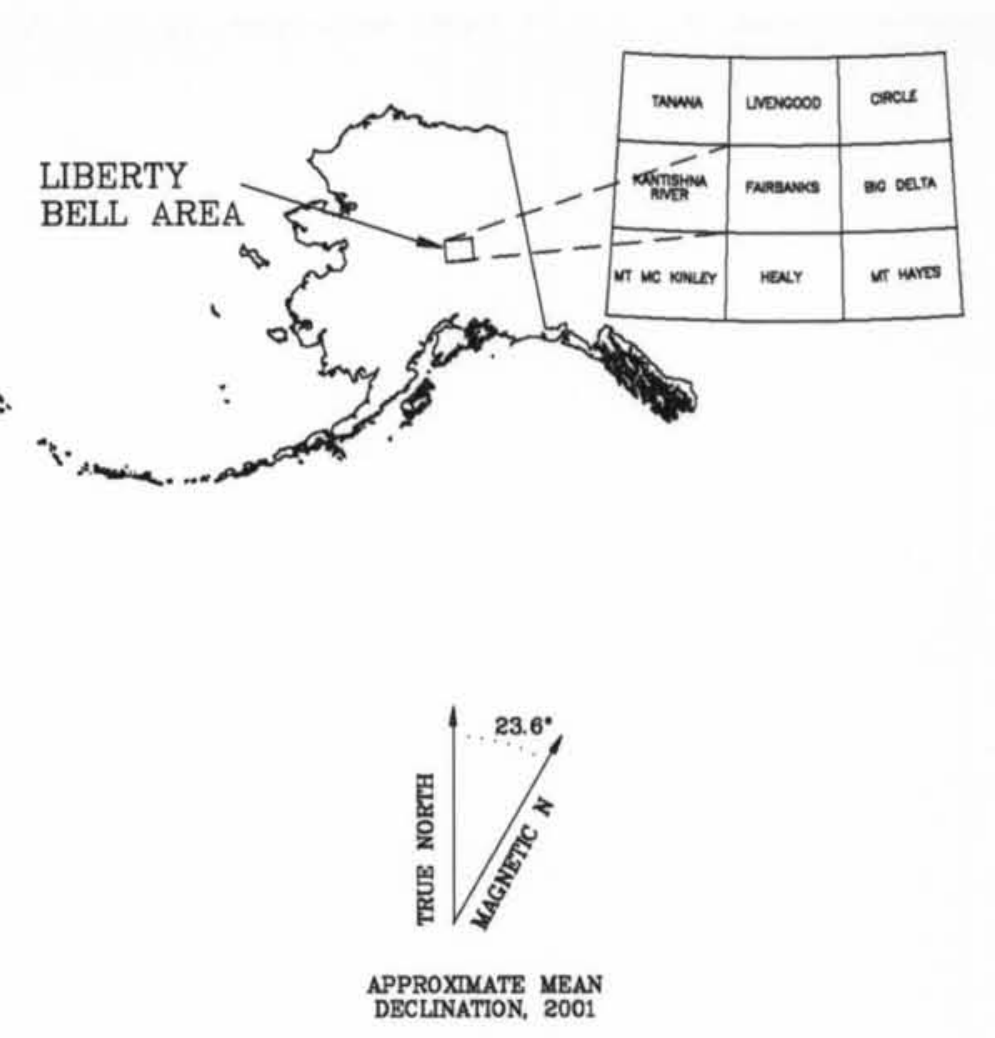

$7200 \mathrm{~Hz}$ COPLANAR RESISTIVITY OF THE LIBERTY BELL AREA, WESTERN BONNIFIELD MINING DISTRICT, CENTRAL ALASKA PARTS OF FAIRBANKS QUADRANGLE 2002

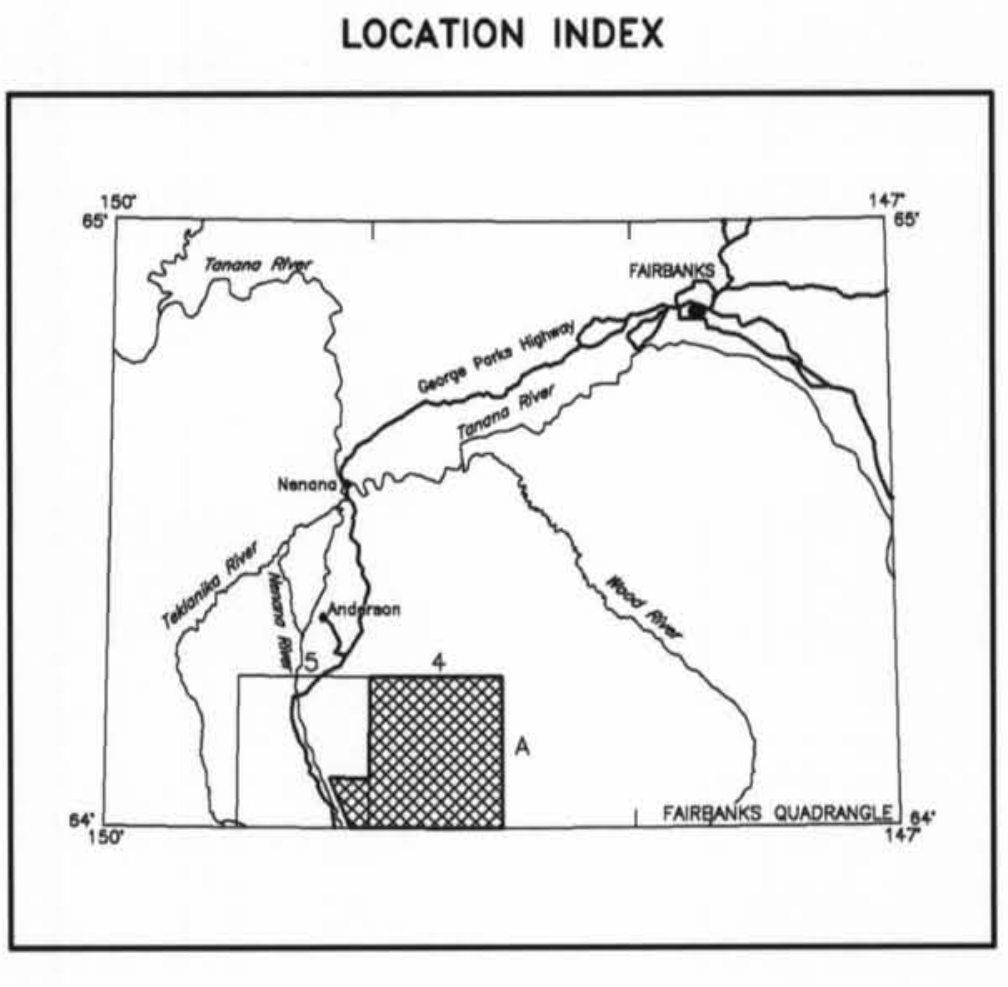

SURVEY HISTORY
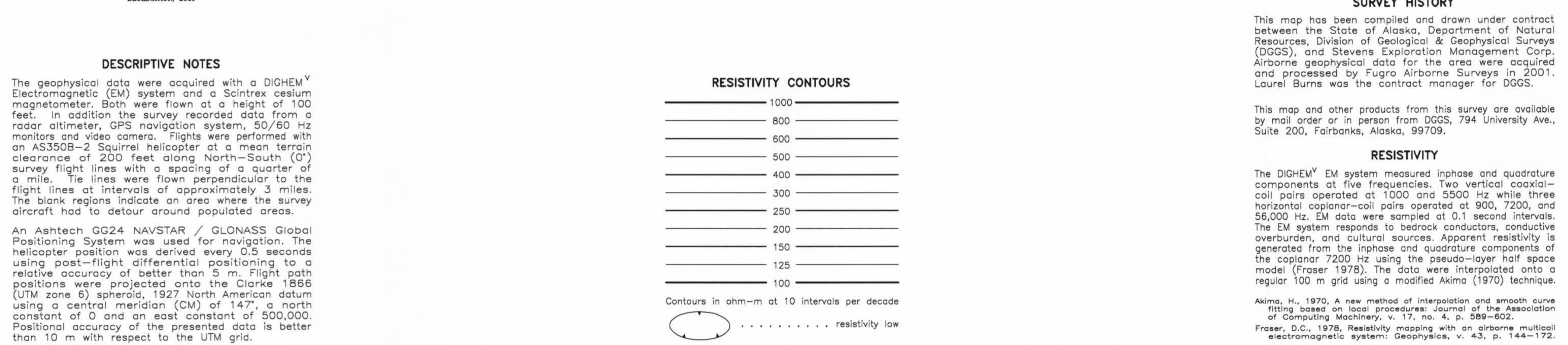


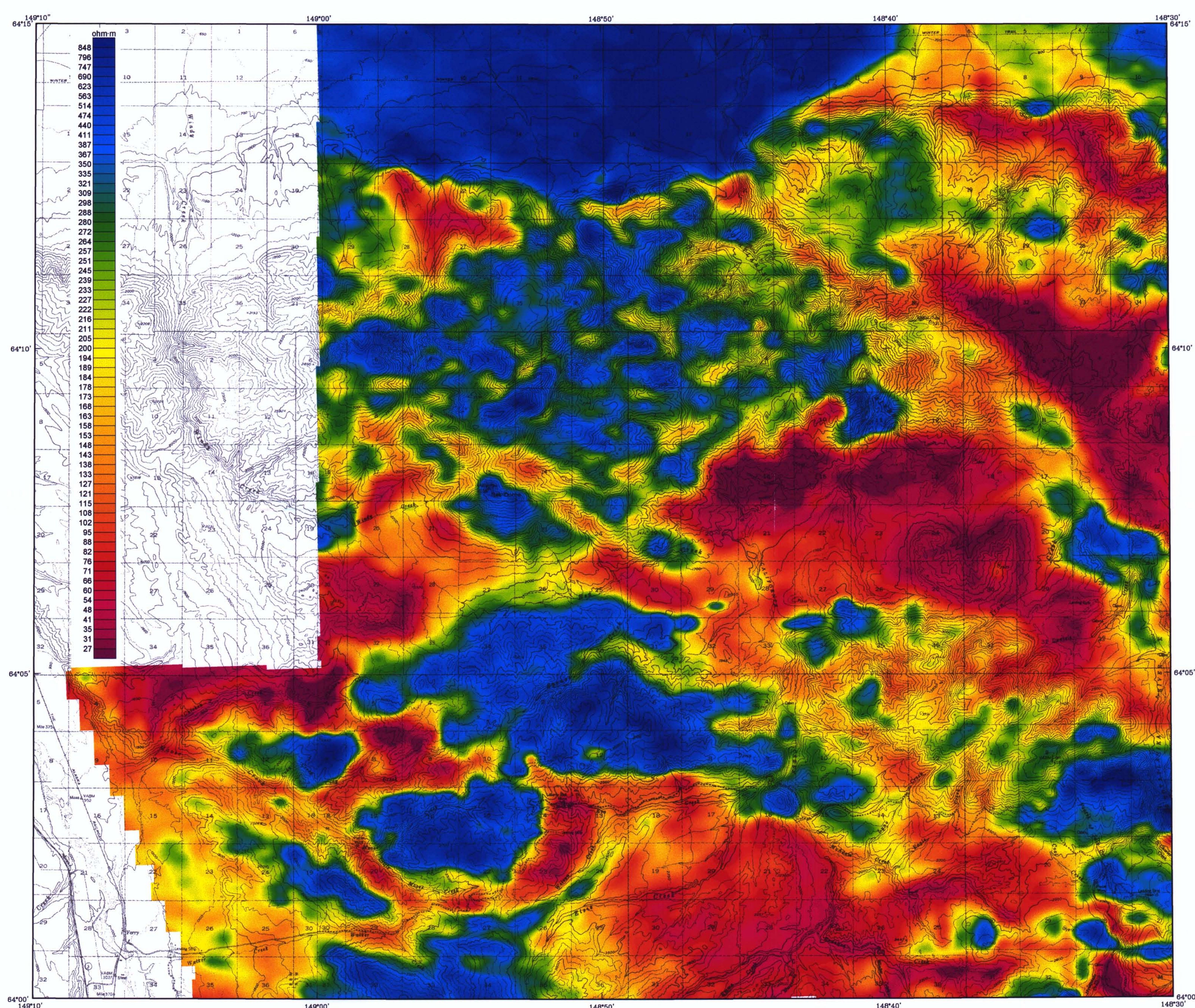

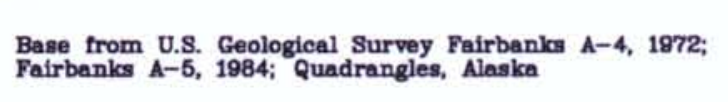

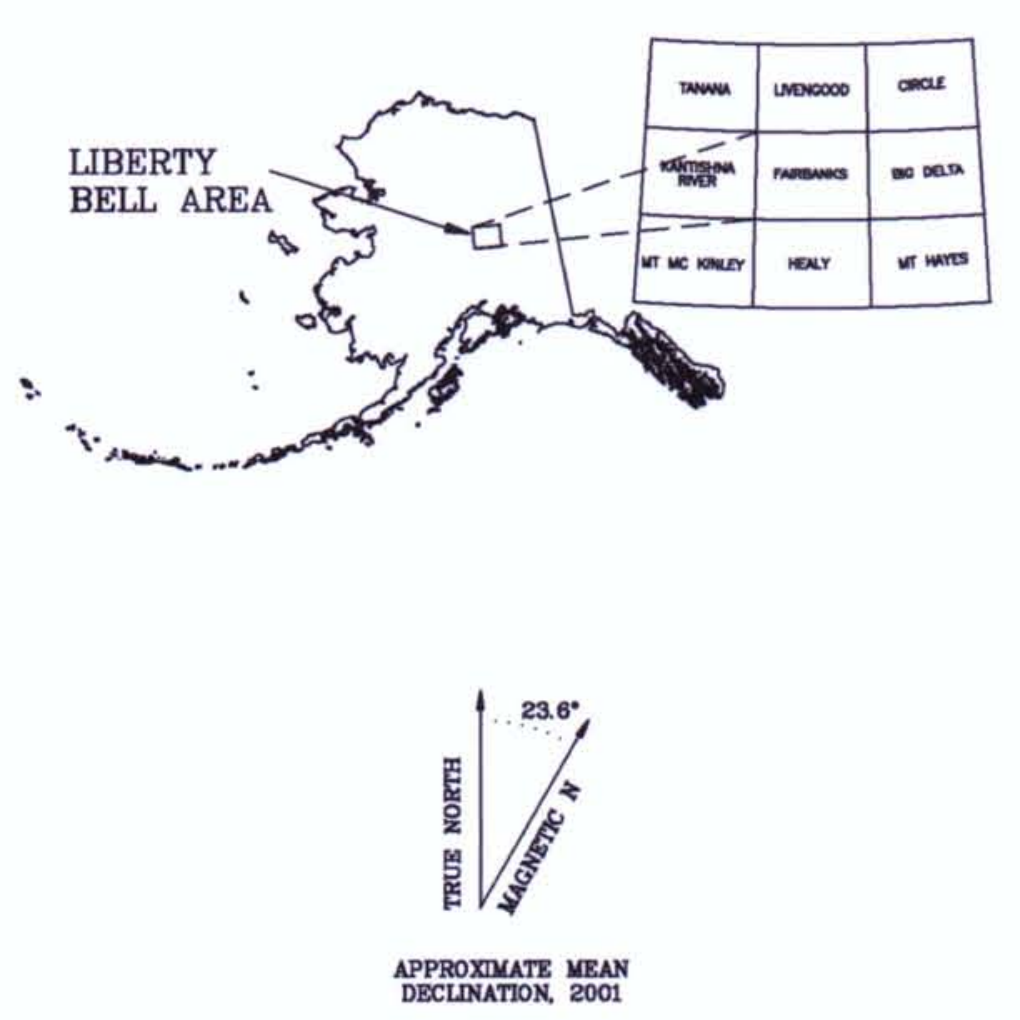

DESCRIPTIVE NOTES

The geophysical dato were acquired with a DIGHEM
Electromagnetic (EM) system and a Scintrex cesium

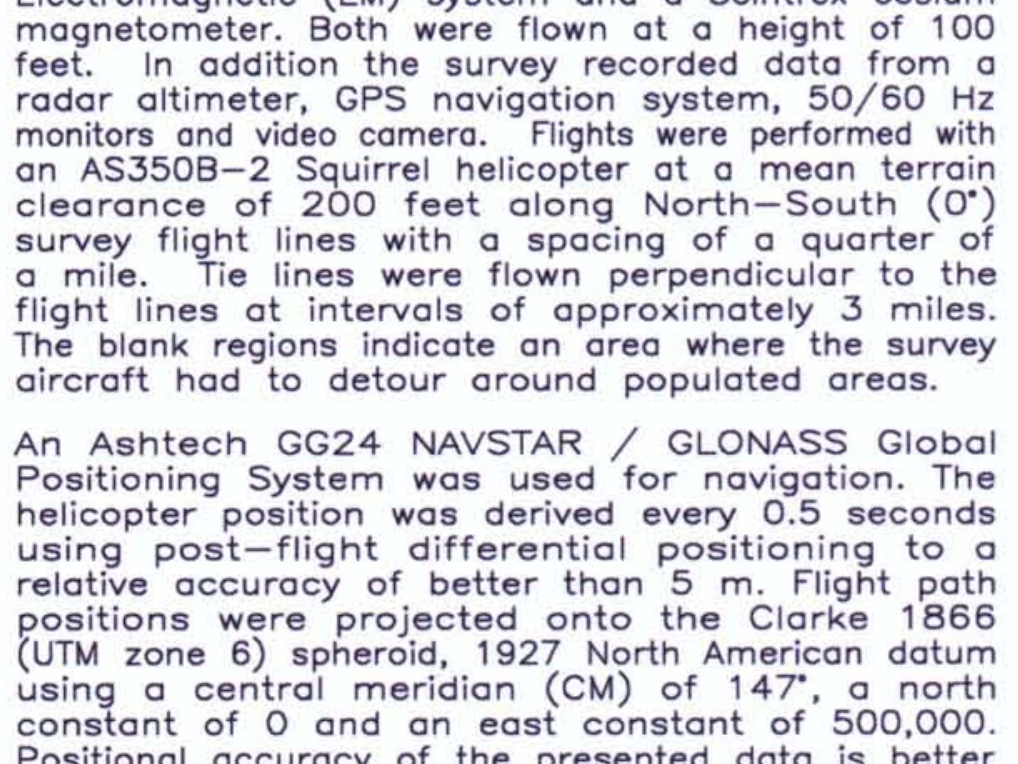

$149^{\circ} 00^{\prime}$

SCALE 1:63,360

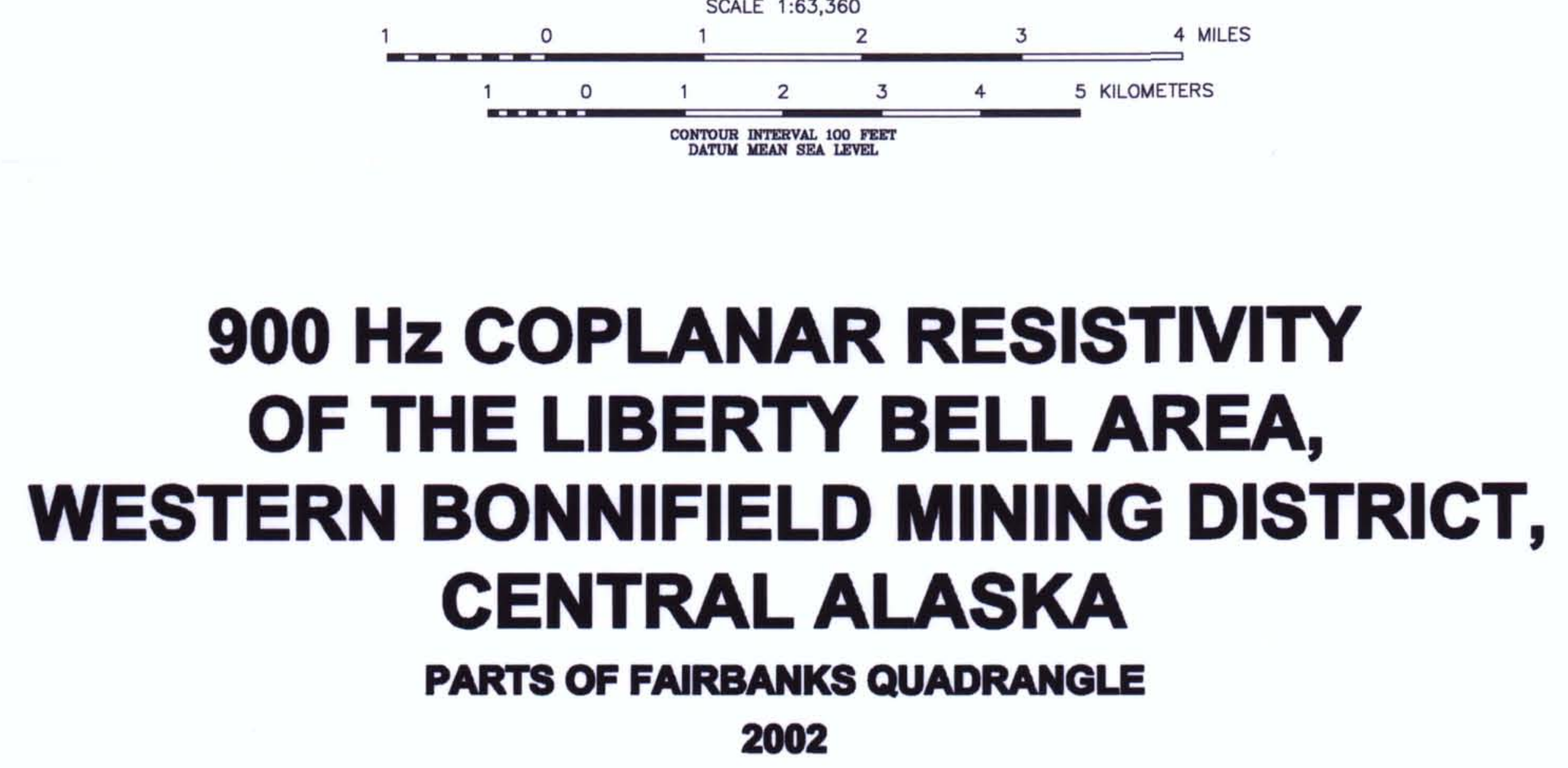

$900 \mathrm{~Hz}$ COPLANAR RESISTIVITY OF THE LIBERTY BELL AREA, CENTRAL ALASKA

2002 


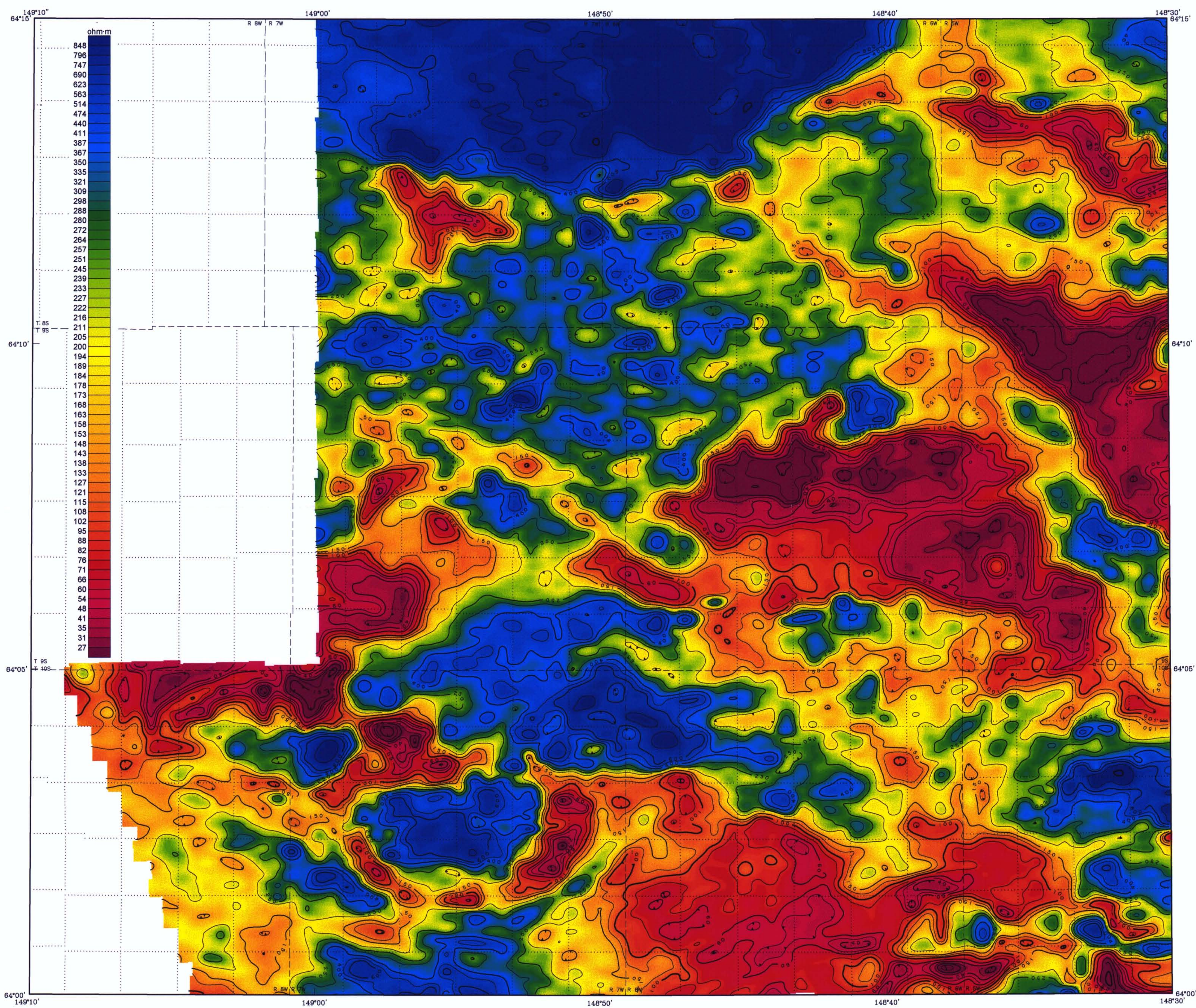

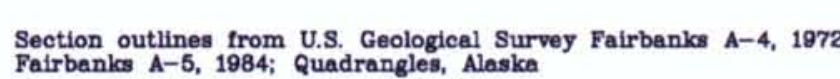

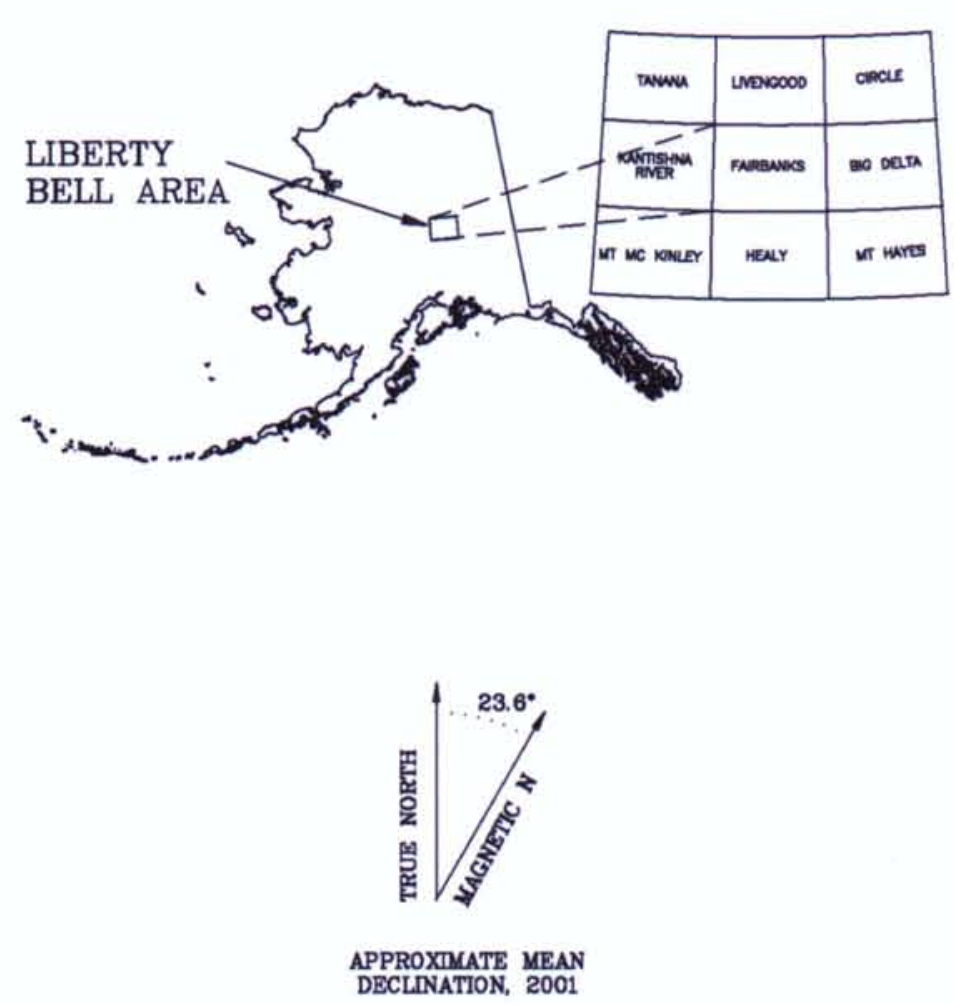

$900 \mathrm{~Hz}$ COPLANAR RESISTIVITY OF THE LIBERTY BELL AREA, WESTERN BONNIFIELD MINING DISTRICT, CENTRAL ALASKA

PARTS OF FAIRBANKS QUADRANGLE 2002

DESCRIPTIVE NOTES

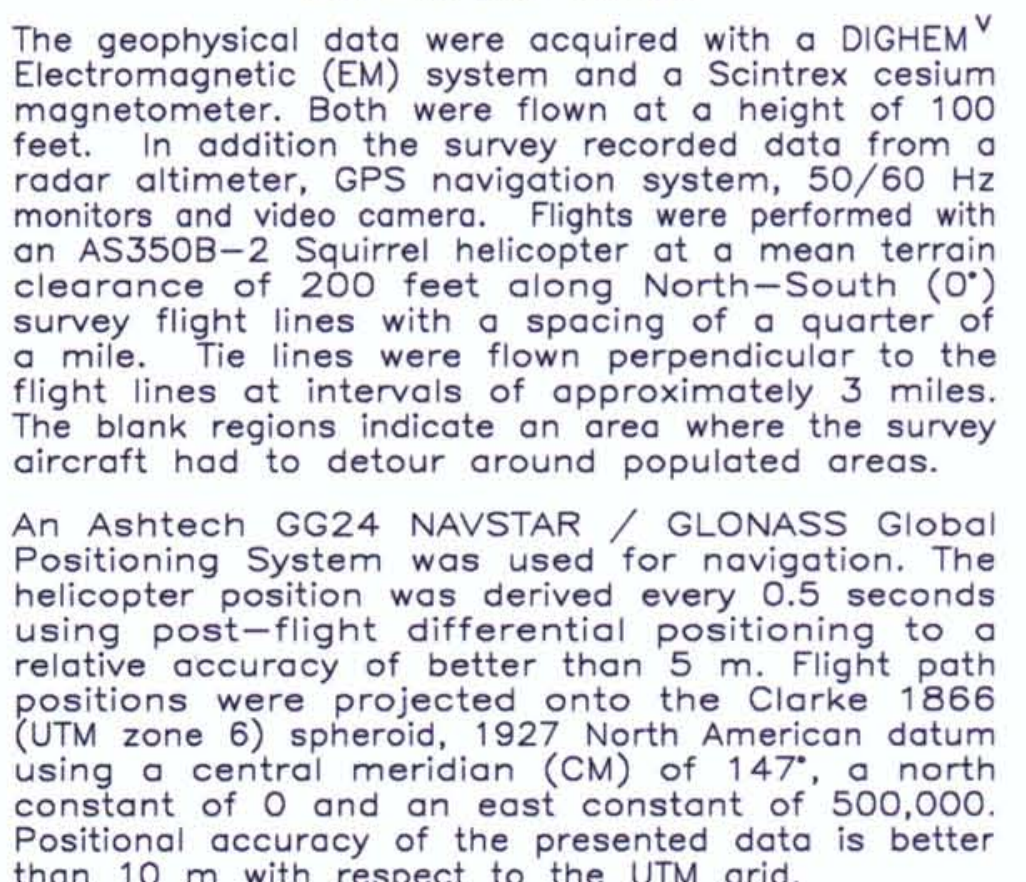

RESISTIVITY CONTOURS

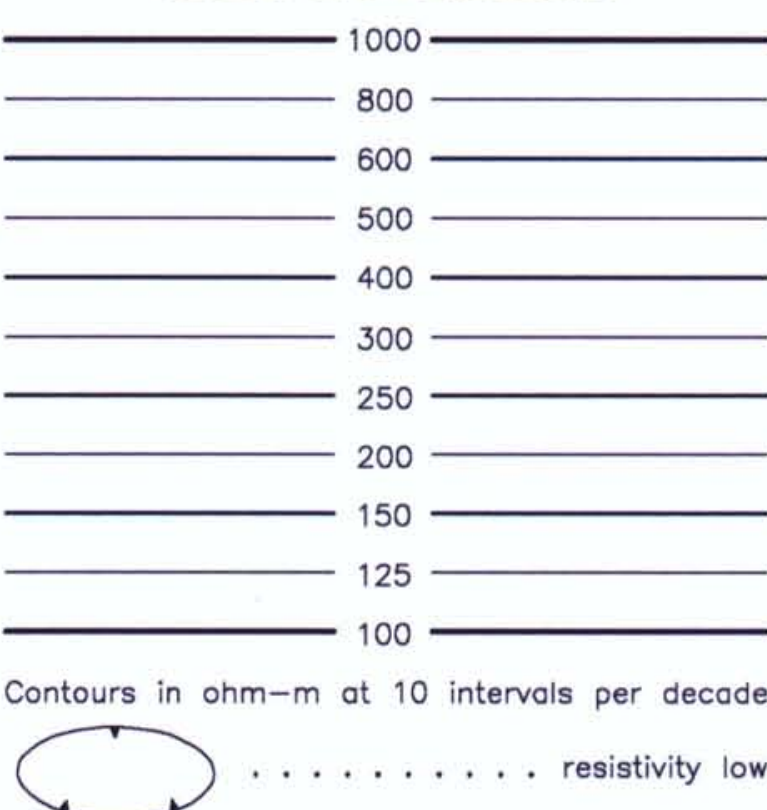

LOCATION INDEX

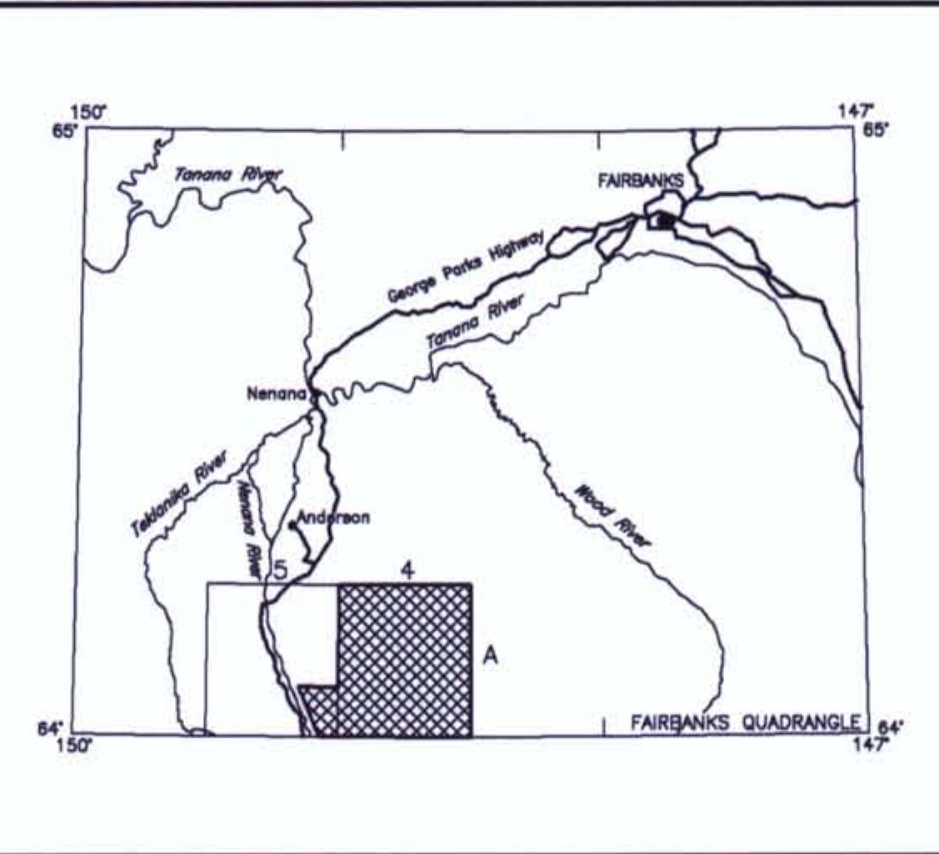

SURVEY HISTORY

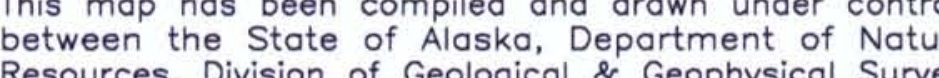

arborne geophysical data for the area were acquired

and processed by Fugro Airborne Surveys in 2001
Lourel Burns wos the contract manager for DGGS.

This map ond other products from this survey are ovailable
by mail order or in person from DOGS, 794 University Ave.,

RESISTIVITY

The DIGHEN EM system measured inphase and quadroture
components at five frequencies. Two vertical coaxial-

coil pairs operated ot 1000 and $5500 \mathrm{~Hz}$ while three

a s
using the pseudo-layer half spoce

regular $100 \mathrm{~m}$ grid using a modified Akima (

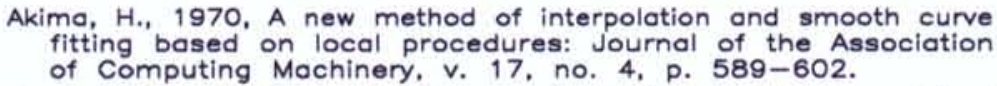




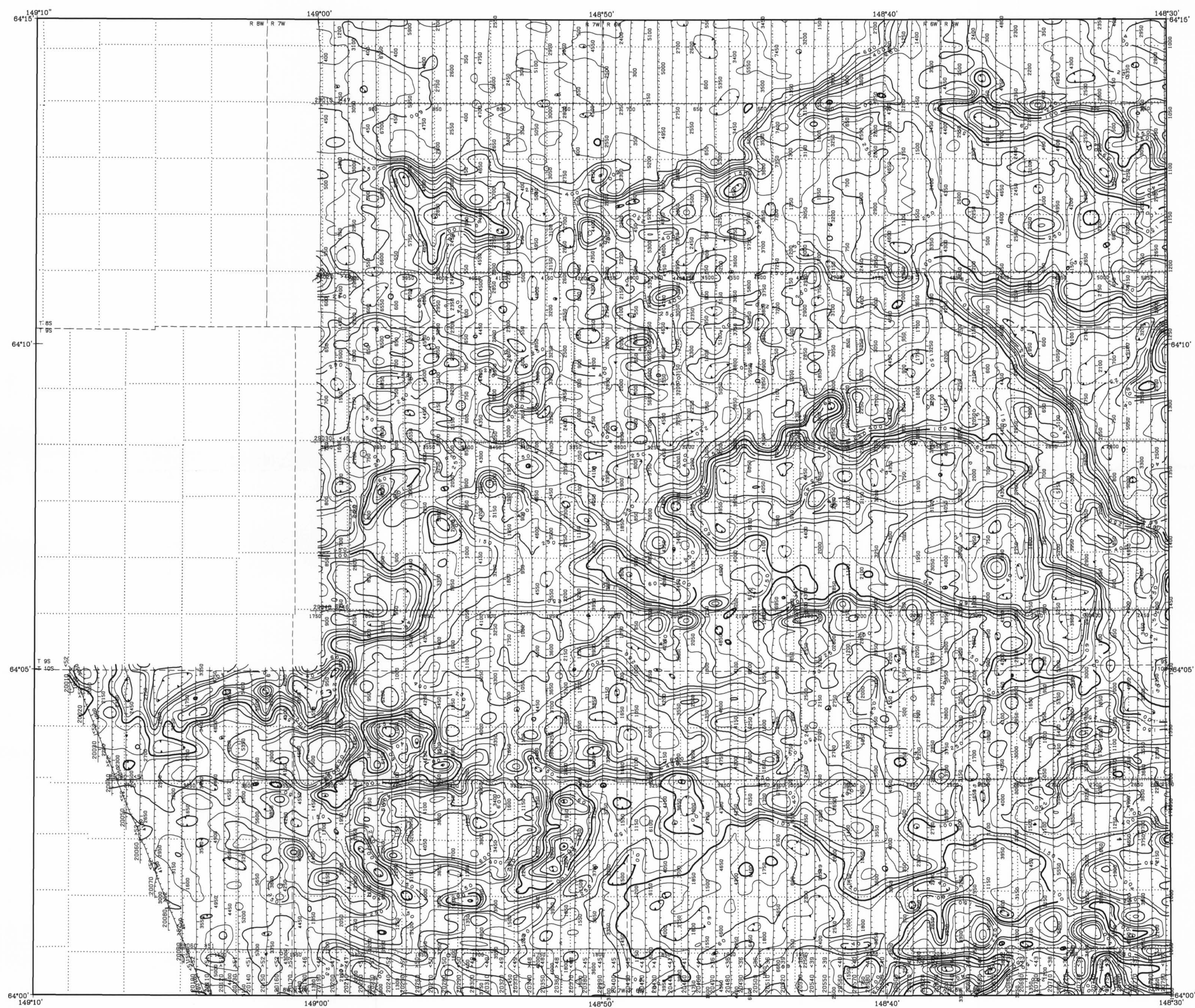

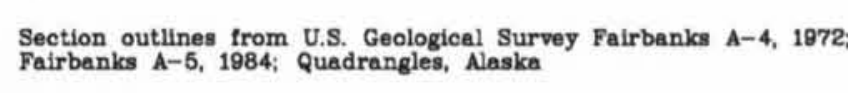

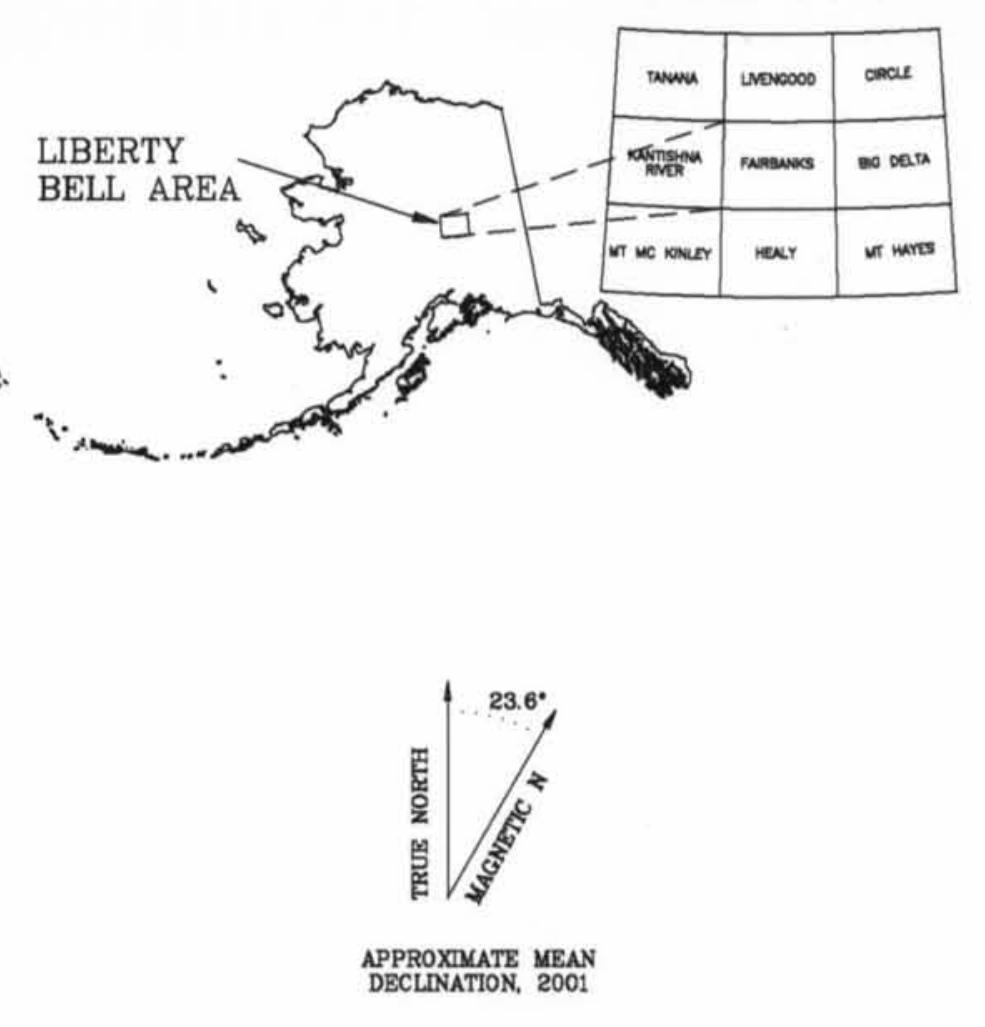

DESCRIPTIVE NOTES

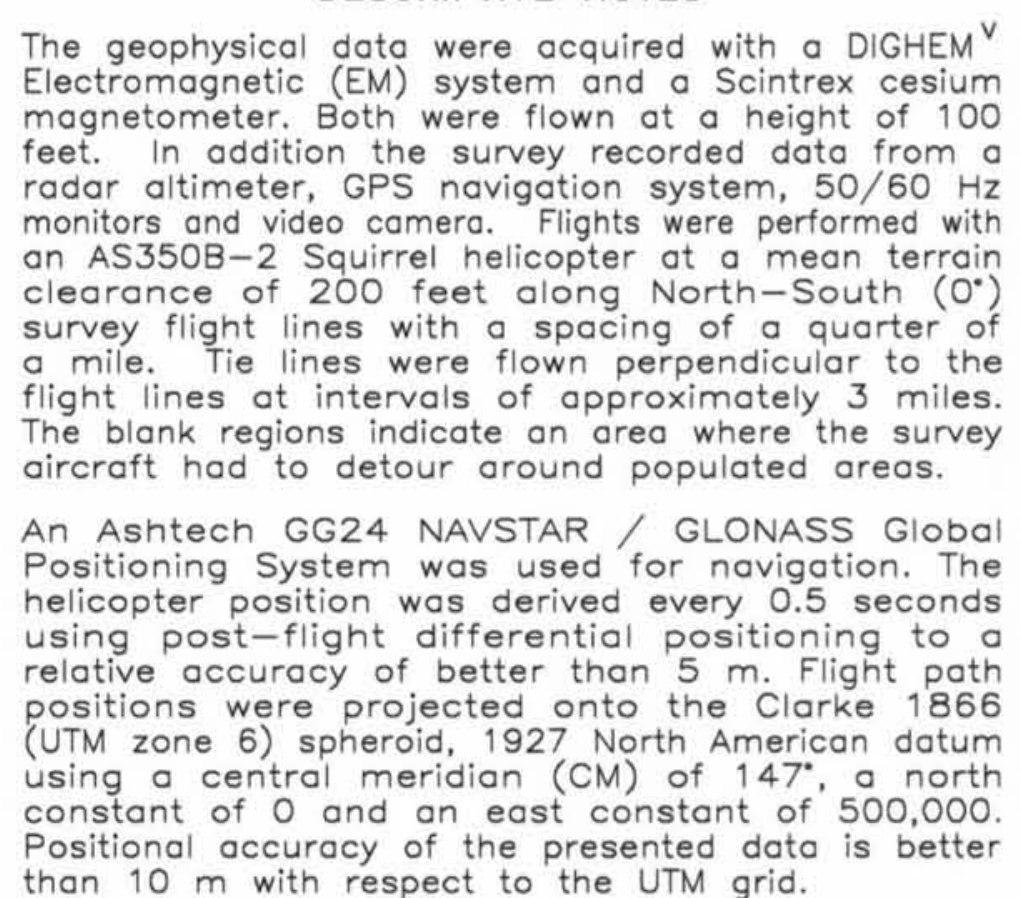

\section{$900 \mathrm{~Hz}$ COPLANAR RESISTIVITY OF THE LIBERTY BELL AREA, WESTERN BONNIFIELD MINING DISTRICT, CENTRAL ALASKA PARTS OF FAIRBANKS QUADRANGLE 2002}

RESISTIVITY CONTOURS

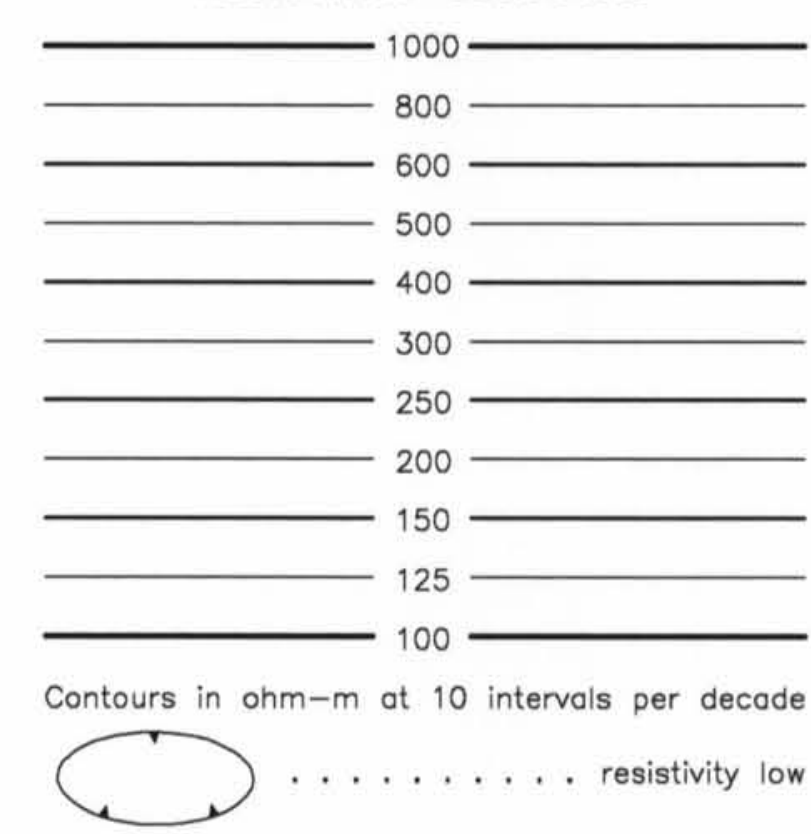

LOCATION INDEX

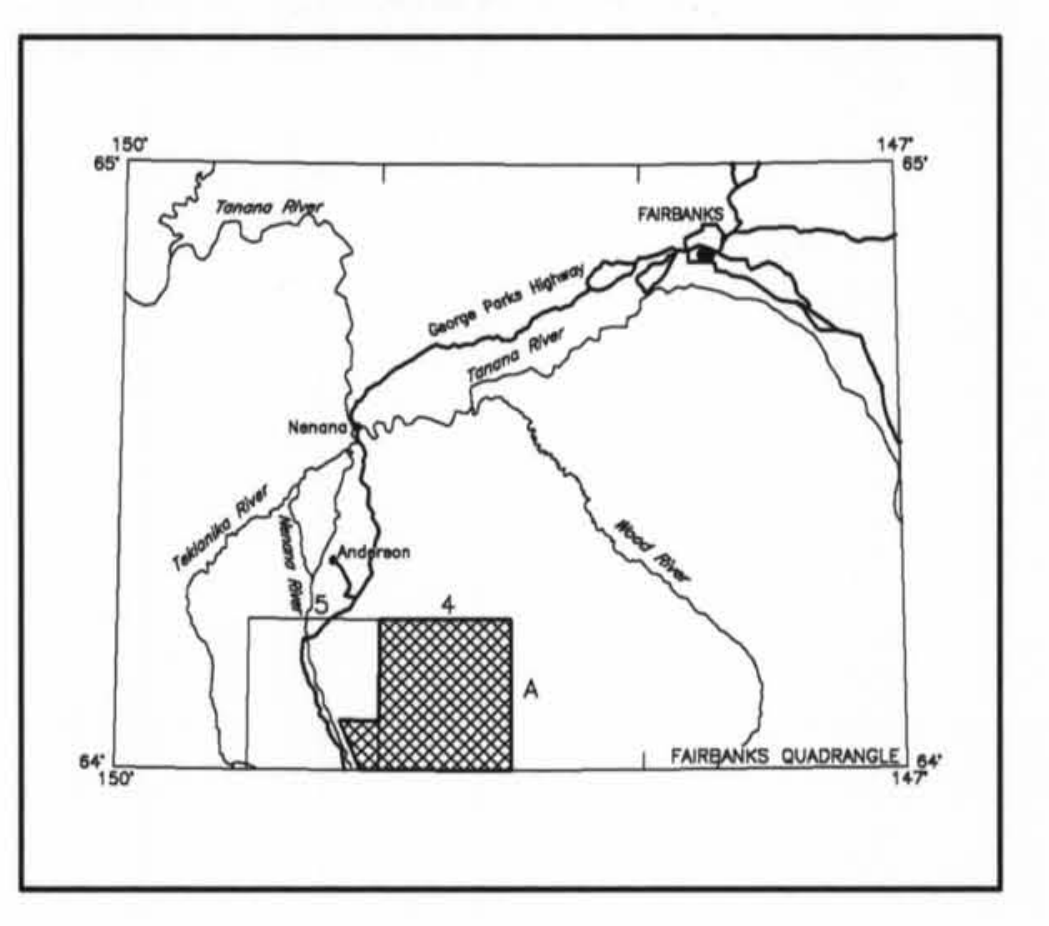

SURVEY HISTORY

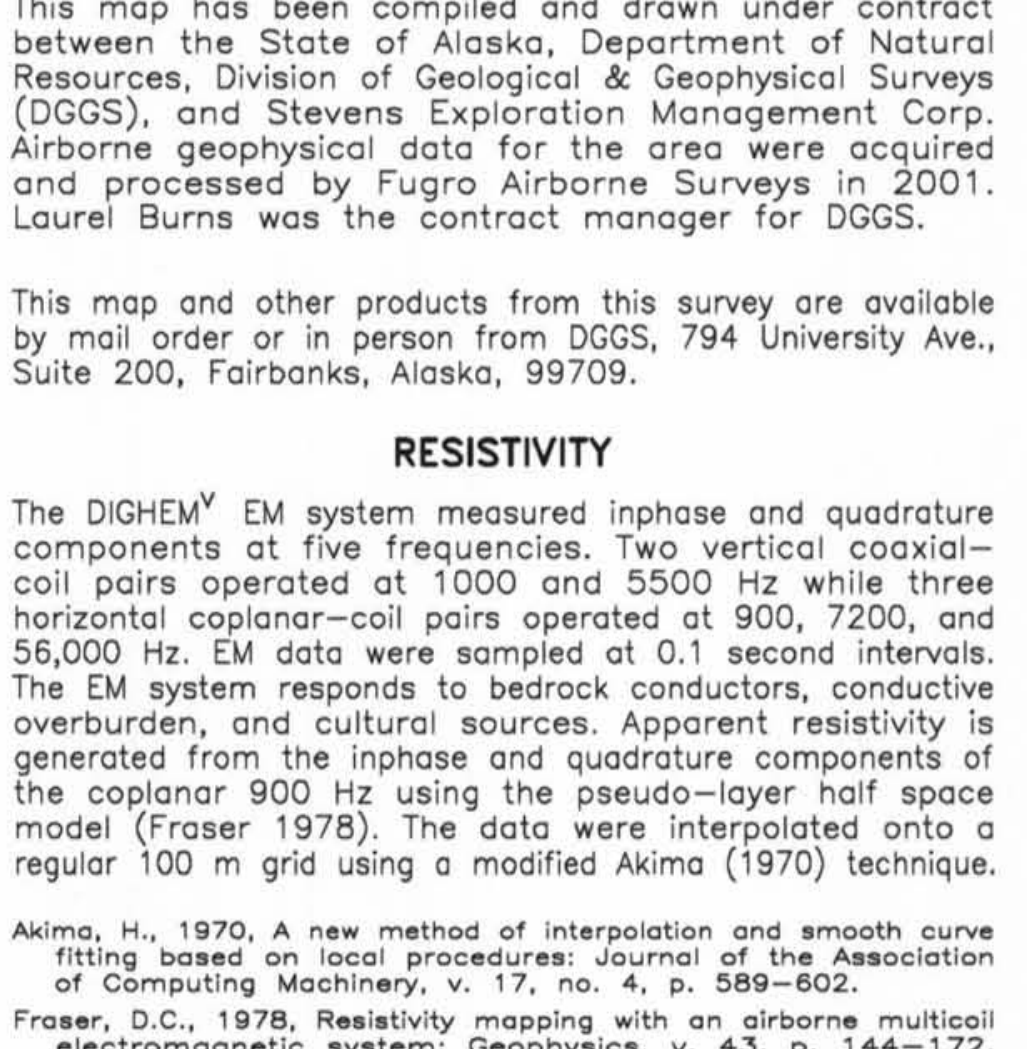




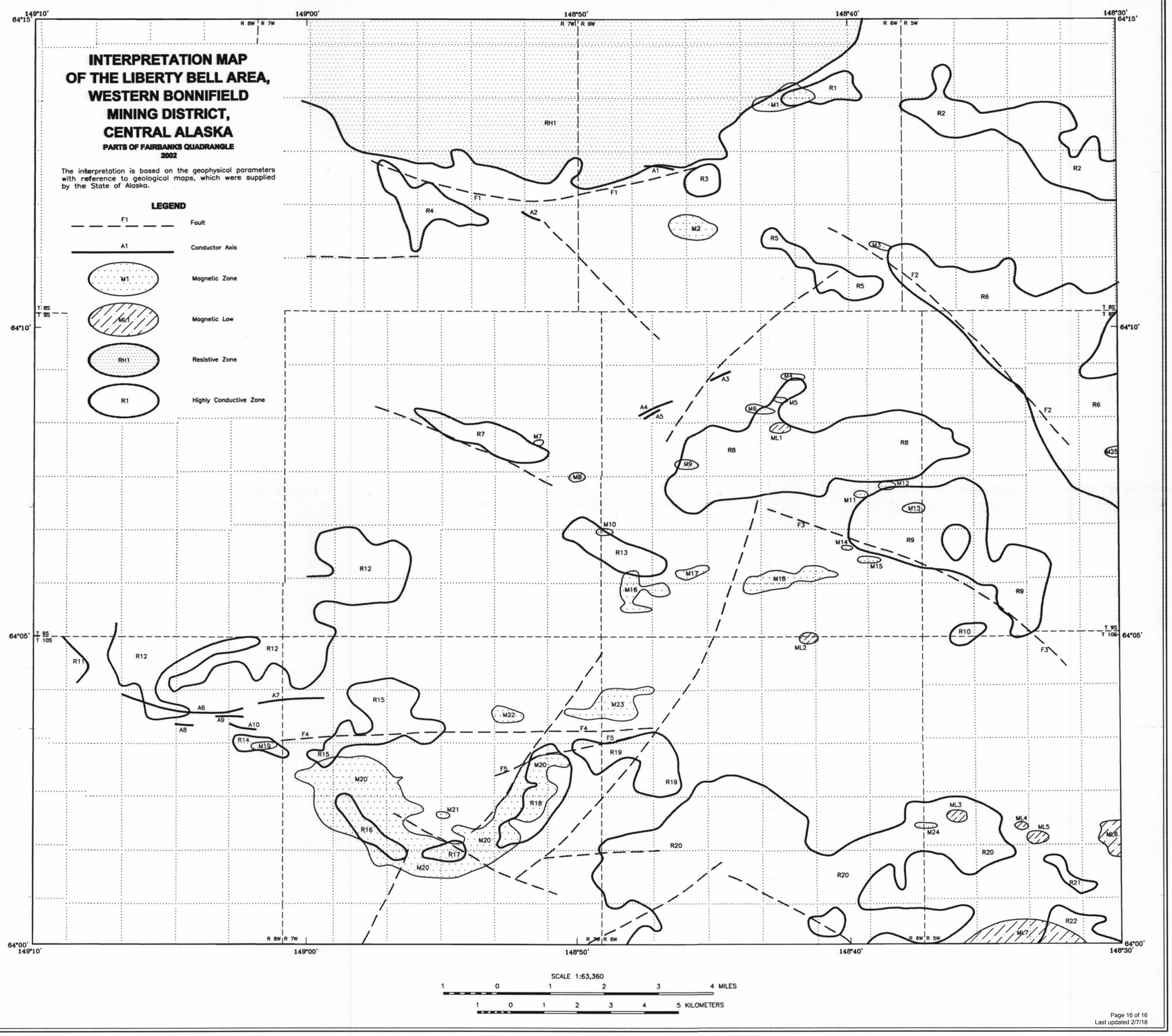

